\title{
INDIVIDUAL INVESTORS AND FINANCIAL DISCLOSURE
}

by

Alastair Lawrence

A thesis submitted in conformity with the requirements

for the degree of Doctor of Philosophy

Joseph L. Rotman School of Management

University of Toronto

June, 2011

(C) Copyright by Alastair Lawrence (2011) 


\title{
INDIVIDUAL INVESTORS AND FINANCIAL DISCLOSURE
}

\author{
Alastair Lawrence \\ A thesis submitted in conformity with the requirements \\ for the degree of Doctor of Philosophy \\ Joseph L. Rotman School of Management \\ University of Toronto
}

June, 2011

\begin{abstract}
Using detailed data of individual investors, this dissertation investigates whether and how individuals use financial disclosure and analysts' signals. Chapter 1 shows that, on average, individuals invest more in firms with readable, concise, and transparent financial disclosures. The results indicate that these relations are less pronounced for overconfident investors, and that individual investors appear to place a greater weighting on such financial disclosure attributes relative to institutional investors. In supplementary analyses, I further examine cross-sectional variations among individuals in their use of disclosure, and find two main subgroups that do not display a preference for accessible and transparent disclosures. The first subgroup is speculative investors, whose investment strategies rely on conjecture rather than knowledge, and the second subgroup is financially literate investors, those with lower information processing costs. These findings support the notion that more accessible and transparent disclosures are used by those individuals who need them the most: i.e., the average American. Lastly, I examine whether individuals' investment performance varies with financial disclosure attributes and show that individuals' returns are, on average, increasing in firms with more accessible and transparent disclosures.
\end{abstract}


Chapter 2 examines how individuals react to revisions in analysts' recommendations and earnings forecasts. First, the analyses show that individuals' abnormal trading activity increases by 30 percent in response to analysts' recommendation revisions and by 15 percent in response to analysts' earnings forecast revisions. Second, the analyses indicate that 47 percent of individuals trade consistently with analyst guidance and 53 percent trade contrarian to analysts' guidance, which opposes the belief that individuals are a homogenous group of investors. The contrarian behavior is most common in response to analyst downgrades (i.e., purchasing after downgrades) and is most evident among individuals with better prior performance, individuals who trade infrequently, men, and older individuals. Lastly, the study provides evidence suggesting that trading contrarian to analysts is in general hazardous to individuals' financial health. Taken together, the results indicate that individuals respond to analyst guidance and that individuals' use of analyst guidance varies significantly with respect to their personal attributes. 


\section{ACKNOWLEDGMENTS}

I thank my supervisor, Ole-Kristian Hope, for his amazing support and mentorship throughout my time at Rotman-I couldn't imagine a better supervisor. I also thank the other members of my dissertation committee: Gus De Franco, David Goldreich, Gordon Richardson, and Michael Welker (the external reviewer) for their excellent comments and guidance. I am grateful to Terrance Odean for providing the discount brokerage data, to Feng Li for providing the 10-K readability data, and to Linda Myers for providing the AIMR disclosure rankings. I dedicate this dissertation to my family; specifically, to my wife and to my parents, as I couldn't have got to this stage without their love and support. 


\section{TABLE OF CONTENTS}

ABSTRACT

ACKNOWLEDGEMENTS iv

TABLE OF CONTENTS $\quad$ v

LIST OF TABLES _ii

LIST OF FIGURES

LIST OF APPENDICES $\quad$ x

CHAPTER 1 - INDIVIDUAL INVESTORS AND FINANCIAL DISCLOSURE 1

1.1 INTRODUCTION 1

1.2 BACKGROUND, LITERATURE REVIEW, AND HYPOTHESES 5

1.2.1 Background $\quad 5$

1.2.2 Literature Review $\quad 8$

1.2.3 Hypotheses Development 10

1.3 SAMPLE, METHODS, AND VARIABLE MEASUREMENT 15

1.3.1 Sample $\quad 15$

$\begin{array}{ll}\text { 1.3.2 Methods and Variable Measurement } & 17\end{array}$

$\begin{array}{ll}1.4 \text { RESULTS } & 21\end{array}$

1.4.1 Descriptive Statistics and Correlations 21

1.4.2 Multivariate Analyses 22

$\begin{array}{ll}1.5 & \text { ADDITIONAL ANALYSES }\end{array}$

1.5.1 Investment Strategy and Financial Literacy 25

1.5.2 Excess Returns Analyses $\quad 27$

$\begin{array}{ll}\text { 1.5.3 Information Environment } & 27\end{array}$

1.5.4 Changes Analyses 28

1.5.5 Additional Individual and Firm Level Control Variables 29 
1.5.7 Disclosure Score Sub-Components 32

1.5.8 2SLS Regressions 33

1.5.9 Household Level 33

1.5.10 Alternative Windows 33

1.5.11 Excluding Equity 34

1.5.12 EDGAR Fillings $\quad 34$

1.6 CONCLUSION - CHAPTER 1

CHAPTER 2 - INDIVIDUAL INVESTORS AND ANALYSTS' SIGNALS 36

$\begin{array}{ll}2.1 \text { INTRODUCTION } & 36\end{array}$

2.2 RELATED LITERATURE AND HYPOTHESES 40

$\begin{array}{ll}\text { 2.2.1 Related Literature } & 40\end{array}$

2.2.2 Hypotheses Development $\quad 42$

2.3 SAMPLE, METHODS, AND VARIABLE MEASUREMENT 45

2.3.1 Sample $\quad 45$

$\begin{array}{ll}\text { 2.3.2 Methods and Variable Measurement } & 47\end{array}$

$\begin{array}{lr}2.4 \text { RESULTS } & 50\end{array}$

2.4.1 Event Study: Individuals’ Abnormal Reactions $\quad 50$

2.4.2 Multivariate Analyses $\quad 54$

2.5 CONCLUSION - CHAPTER $2 \quad 59$

$\begin{array}{ll}\text { REFERENCES } & 60\end{array}$ 


\section{LIST OF TABLES}

Table 1: $\quad$ Sample Selection Procedures $\quad 79$

Table 2: — PANEL A: Descriptive Statistics $\quad 80$

- PANEL B: Pearson Correlation Matrix-Annual Report Sample 81

- PANEL C: Pearson Correlation Matrix-Disclosure Score Sample $\quad 82$

Table 3: Individual Investors' Shareholdings and Financial Disclosure 83

Table 4: $\quad$ Individual Investors' Overconfidence and Financial Disclosure 84

Table 5: Financial Disclosure: Individual versus Institutional Investors' Shareholdings 86

Table 6: $\quad$ Investment Strategy and Financial Disclosure 88

Table 7: $\quad$ Financial Literacy and Financial Disclosure 90

Table 8: $\quad$ Individual Investors’ Excess Returns and Financial Disclosure 92

Table 9: $\quad$ Information Environment and Financial Disclosure 93

Table 10: Changes in Financial Disclosure and Changes in Next-Year's Individual 95 Investors' Shareholdings

Table 11: Individual Investors' Shareholdings and Financial Disclosure: Additional 96 Individual Controls

Table 12: Individual Investors' Shareholdings and Financial Disclosure: Additional 98 Firm-Level Controls

Table 13: Individual Investors' Shareholdings and Financial Disclosure: Controlling for 100 Earnings Quality

Table 14: Individual Investors' Shareholdings and Financial Disclosure: Firm-Level 102 Clustering

Table 15: Individual Investors' Shareholdings and Financial Disclosure: Alternative 103 Holdings Measure

Table 16: Individual Investors' Overconfidence and Financial Disclosure: Alternative 104 Overconfidence Measures

Table 17: Individual Investors' Shareholdings and Financial Disclosure: Disclosure Score Sub-Components 
Table 18: $\quad$ 2SLS Regressions of Individual Investors' Shareholdings and Financial Disclosure

Table 19: Individual Investors' Shareholdings and Financial Disclosure: Performed at the Household Level

Table 20: Individual Investors' Shareholdings and Financial Disclosure: Six Month Holding Window

Table 21: Individual Investors' Shareholdings and Financial Disclosure: Without EQUITY

Table 22: Individual Investors' Shareholdings and Financial Disclosure: EDGAR Mandatory Filings

Table 23: Trading Consistency Analyses: Descriptive Statistics

Table 24: Trading Consistency Regression Analyses: Recommendations and Earnings 114 Forecast Revisions

Table 25: Trading Consistency Regression Analyses: Analysts’ Recommendation

Revisions

Table 26: Trading Consistency Regression Analyses: Analysts' Earnings Forecast Revisions

Table 27: Individuals' Six Month Returns Following Analyst Guidance: Univariate Analysis

Table 28: Individuals' Future Returns Following Analyst Guidance: Regression Analysis 118

Table 29: Individuals’ Attributes and Future Returns Following Analyst Guidance: Regression Analysis 


\section{LIST OF FIGURES}

Figure 1: _ PANEL A: Individuals' Reaction to Analysts' Recommendation Revisions 70

— PANEL B: Individuals’ Reaction to Analysts’ Earnings Forecast Revisions

- PANEL C: Individuals' Reaction to Analysts' Recommendation versus Earnings Forecast Revisions

Figure 2: _ PANEL A: Individuals' Reaction to Analysts' Upgraded Recommendations

- PANEL B: Individuals' Reaction to Analysts' Upgraded Earnings Forecasts

Figure 3: - PANEL A: Individuals' Reaction to Analysts’ Downgraded Recommendations

- PANEL B: Individuals' Reaction to Analysts' Downgraded Earnings Forecasts

Figure 4: - PANEL A: Individuals’ versus All Market Participants' Reaction to Analysts' Recommendation Revisions

- PANEL B: Individuals' versus All Market Participants' Reaction to Analysts' Earnings Forecast Revisions 


\section{LIST OF APPENDICES}

Appendix A: Chapter 1 Variable Definitions

Appendix B: Chapter 2 Variable Definitions 


\section{CHAPTER 1 - INDIVIDUAL INVESTORS AND FINANCIAL DISCLOSURE}

\subsection{INTRODUCTION}

Understanding individual investors' financial reporting needs and how they use financial information is an important concern for standard setters and regulators. For instance, in 2009, the Securities and Exchange Commission (SEC) announced the formation of the Investor Advisory Committee (IAC) whose central aim is to assess what changes are necessary to the reporting framework to ensure individual investors have the financial information that they need and that they can use (SEC 2009). Furthermore, in 2010, the International Accounting Standards Board (IASB) launched a similar initiative aimed at enhancing individuals' participation in the development of International Financial Reporting Standards (IFRS) (IASB 2010).

Using detailed data of individual investors, this study investigates whether individuals invest more in firms with accessible and transparent financial disclosures, and whether there is variation across individuals in their use of financial disclosure. Analytical studies show that firms with greater private information are more risky to uninformed investors and hence, they decrease their demand for such firms (e.g., Diamond and Verrecchia 1991; Easley and O'Hara 2004). Consistent with these findings, I predict that, ceteris paribus, individuals' investments are increasing in the accessibility and transparency of financial disclosures. Moreover, supported by a growing literature suggesting that overconfident individuals place greater weight on their own private information than on public information (e.g., Daniel, Hirshleifer, and Subrahmanyam 1998; Odean 1998; Malmendier and Tate 2005, 2008), I hypothesize that the positive relation between individuals' shareholdings and accessible and transparent financial disclosures is less pronounced for overconfident individuals. Lastly, given that institutions have their own private information (e.g., Bushee and Goodman 2007; Ali, Klasa, and Li 2008) and the possibility that 
informed shareholders prefer less disclosure relative to uninformed shareholders (Kim 1993), I predict that, relative to individual investors, institutional investors place less of an importance on accessible and transparent financial disclosures.

Consistent with the previous literature and recent guidance from the SEC, I use annual report readability and annual report length as measures of disclosure accessibility, and analysts' disclosure scores (AIMR) as a measure of disclosure transparency. In line with Li (2008) and the SEC's (2007) findings, I consider firms with less readable and excessively long annual reports to have less accessible disclosures (e.g., Merton 1987), and firms with higher analysts' disclosure scores to have more informative disclosures and hence, more transparent disclosures (e.g., Lang and Lundholm 1996; Healy, Hutton, and Palepu 1999; Botosan and Plumlee 2002). While the annual report readability and length measures more reflect the form of disclosure, and analysts' disclosure scores more reflect the content of disclosures, the three measures all represent aspects of a firm's overall disclosure quality. The form of disclosure is important, especially to individual investors, as less readable and longer reports require more time and energy to extract relevant information (e.g., Bloomfield 2002). Combined with the limited attention among investors (e.g., Hirshleifer and Teoh 2003) and the fact that noise in communication could decrease information acquisition activities (e.g., Indjejikian 1991), the form of disclosure can significantly impact a firm's overall financial disclosure quality and the amount of information investors can absorb.

The results indicate that individuals invest, on average, more in firms with higher quality disclosures. Specifically, individuals' shareholdings increase in firms with more readable, concise, and transparent financial disclosures. The results further show that that these relations are reduced for overconfident investors, and in a direct comparison of individuals' and institutions' holdings, individual investors appear to place a greater weighting on more 
accessible and transparent financial disclosures relative to institutional investors. The findings are robust to change specifications, to an extensive list of holdings and disclosure control variables, and to alternative variable measurements.

To supplement the main analyses, I further examine cross-sectional variations among individuals in their use of disclosure. First, I investigate whether individuals' use of financial disclosure varies with their investment strategies. Specifically, I examine whether speculative investors, whose investment strategies rely on conjecture rather than knowledge, will be less partial to firms with more accessible and transparent disclosures than growth, income, and conservative investors. The results show that speculative investors do not exhibit a preference for firms with accessible and transparent disclosures; consistent with the notion that speculation would be most appropriate in more opaque environments. Second, I examine whether individuals' use of disclosures varies with financial literacy. Ex ante, it is not obvious whether financially literate individuals would gravitate toward firms with more accessible and transparent disclosures. With their lower transaction processing costs, it is somewhat intuitive that financially literate individuals would be attracted to less accessible disclosures; however, it is unclear how these individuals would respond to more transparent disclosures. For example, financial literate individuals could prefer opaque firms as they can navigate best in such environments or they could prefer transparent firms as they provide more opportunities to process and analyze information. Ex post, I find that financially literate individuals do not exhibit a preference for firms with accessible and transparent disclosures, indicating that financially literate individuals appear to prefer more opaque environments to exploit their 
competitive advantages. ${ }^{1}$ Third, I investigate how other characteristics such as diversification, age, and gender affect individuals' use of financial disclosures. I find that all main inferences hold controlling for these additional individual characteristics; however, I do not find evidence suggesting that these characteristics separately influence how individuals use financial disclosures.

To assess whether more accessible and transparent disclosures aid the average individual in making effective investments, I also examine whether there is an association between individuals' investment performance and financial disclosure. I find that individual investors' excess returns are increasing in more accessible and transparent disclosures, suggesting that such disclosure attributes reduce the average individuals' information disadvantage relative to more sophisticated investors. Lastly, I examine how individuals' use of disclosure varies with the firm's information environment. Specifically, I investigate whether individuals' use of financial disclosure varies with respect to the level of certainty conveyed through the firms' key fundamental signals. The results of this analysis indicate that when firms' fundamentals are weaker, individuals rely more on accessible and transparent disclosures to reduce uncertainty.

This study is the first to empirically relate individuals' investments to disclosure accessibility and transparency, and to provide evidence suggesting how individuals' use of disclosure varies with their individual characteristics. Taken together, the results suggest that more accessible and transparent disclosures are used by those individuals who need them the most: i.e., the average American. Moreover, it provides initial evidence examining how individuals' returns vary with financial disclosure attributes. Furthermore, by making comparisons across individuals, and between individuals and institutions, the study provides

\footnotetext{
1 These findings could differ from the institutional investor findings as financially literate individuals are not accountable to clients where institutional investors are-reflecting the possible interaction between risk tolerance, financial literacy, and the use of disclosure.
} 
empirical evidence relating to Verrecchia's (2001) concern that, "if one makes market agents (e.g., investors, shareholders, etc.) sufficiently diverse, it is difficult, if not impossible, for disclosure to yield a positive benefit for everyone." Specifically, my paper provides suggestive evidence that the benefits of more accessible and transparent disclosures vary across diverse financial statement users.

The following section provides background information, reviews important literature, and develops testable hypotheses concerning the relation between individual investors' shareholdings and financial disclosure. Section 1.3 describes sample formation, methods, and variable measurement. Section 1.4 presents the empirical results. Section 1.5 provides additional analyses, and Section 1.6 concludes.

\subsection{BACKGROUND, LITERATURE REVIEW, AND HYPOTHESES}

\subsubsection{Background}

Under FASB's Statement of Financial Accounting Concepts (SFAC) No. 1 (FASB 1978) and IASB's Framework for the Preparation and Presentation of Financial Statements (IASC 1989), a primary objective of financial reporting is to provide useful and understandable information that will aid investors and other financial statements users in predicting the future cash flows of a firm. Consistent with this objective, there is extensive research examining how the market as a whole, institutional investors, and analysts respond to more useful and understandable financial disclosures. Specifically, several studies document that higher quality financial disclosures are positively associated with general market liquidity (e.g., Diamond and Verrecchia 1991; Welker 1995; Healy et al. 1999), institutional ownership (e.g., Healy et al. 1999; Bushee and Noe 2000), analyst forecast accuracy and analyst following (e.g., Barron, Kim, 
Lim, and Stevens 1998; Lang and Lundholm 1996; Hope 2003), and are negatively associated with the ex ante cost of equity capital (e.g., Leuz and Verrecchia 2000; Easley and O'Hara 2004; Francis, Khurana, and Pereira 2005) and agency costs (e.g., Berger and Hann 2007; Hope and Thomas 2008). SFAC No. 1 states that "financial reporting should provide information that can be used by all—nonprofessionals as well as professionals—who are willing to learn to use it properly" (FASB 1978, 11). Yet, as reflected by the foregoing studies, the vast majority of the empirical disclosure research relates to the market as a whole or to professionals, as opposed to individual investors.

Contrary to the notion that individual investors rely only on information from intermediaries (e.g., analysts, media, and data providers), evidence exists that individual investors read and use companies' financial disclosures to make investment decisions. For example, in a survey of 1,600 retail investors commissioned by the Task Force to Modernize Securities Legislation, $56 \%$ of stockholders responded that they read and use financial statements to make investment decisions (Deaves, Dine, and Horton 2006). Moreover, approximately 50\% of stockholders in this survey reported that they find annual financial statements, including management's discussion and analysis (MD\&A), to be useful. On the whole though, relatively little is known about how individuals use financial reporting information and hence, understanding individual investors' financial reporting needs and practices is currently a top priority for the FASB, the IASB, and the SEC. For example, in 2007, the SEC sought and released feedback from individual investors pertaining to their financial disclosure needs. Apart from the general finding that financial disclosure is important to individual investors, the two most common financial disclosure needs of individual investors, noted by the SEC staff speech titled Feedback from Individual Investors on Disclosure (SEC 2007), were as follows: 
"Probably the most familiar theme is plain language. The swamp of legalese found in many annual reports and mutual fund prospectuses can frustrate even the most experienced investor. Not surprisingly, investors consistently have been telling us that disclosures should contain language that the average investor, not the average lawyer, can read and understand."

"In addition to using plain language, investors don't want more information than they need, so less is more. Whether they use the term or not, information overload is a real concern to investors."

Thus, it appears that the readability and the excessive length, what I define as disclosure accessibility, of some financial statements are serious barriers for individual investors to extract relevant information from financial disclosures. The excessive length finding is not completely obvious as more financial disclosure information is often considered to be better than less financial disclosure information. However, in the realm of individual investors, irrelevant details can potentially confuse and misguide individual investors, which in turn could limit their processing of material financial information (Deaves et al. 2006). ${ }^{2}$

In line with concerns that current financial disclosures are inadequate for individual investors, on June 3, 2009, the SEC announced the formation of the Investor Advisory Committee (IAC). The IAC's aim is to give individual investors a greater voice in the commission's work and to assess "what changes are necessary to ensure that investors have the information that they need, when they need it" (SEC 2009). Moreover, the FASB and the IASB have recently requested the opinions of individual investors concerning many of its proposed standards and whether they are satisfied with such proposals. More formally, on April 29, 2010, the Trustees of the International Accounting Standards Committee Foundation and the IASB officially announced the launching of a program "to enhance investors' participation in the development of International Financial Reporting Standards (IFRSs)” (IASB 2010).

\footnotetext{
${ }^{2}$ In addition, several other studies argue that the excessive length of financial statements reflects lower financial disclosure quality (e.g., Li 2008; Miller 2010; Bova, Dou, and Hope 2011).
} 


\subsubsection{Literature Review}

A significant limitation facing any study pertaining to individual investors is that individuals' trading data are generally not publicly available. The majority of prior research aimed at understanding how individuals respond to financial reporting information use small trades as a proxy for individuals' trades (e.g., Lee 1992; Bhattacharya 2001; Bushee, Matsumoto, and Miller 2003, 2004; Bhattacharya, Black, Christensen, and Mergenthaler 2007; De Franco, Lu, and Vasvari 2007; Miller 2010). Related to the current study, Bushee et al. (2003) document a positive relation between the frequency of small trades and open conference calls, and Miller (2010) shows a negative relation between the frequency of small trades and financial complexity. However, a concern with this literature is whether the measures capture the separate trading behaviors of small and large investors by using a trade-size classification rule, as institutions have incentives to avoid trade detection (Kyle 1985) and employ order-splitting techniques to disguise their trades (Bertsimas and Lo 1998; Campbell et al. 2009). Specific to this concern, Finucane (2000) and Odders-White (2000) find that trades in illiquid stocks and small trades tend to be more frequently misclassified, and Campbell et al. (2009) provide evidence suggesting that simple size cutoffs used in previous studies are inaccurate and can lead to incorrect inferences. ${ }^{3}$ Moreover, without data specific to the individual investors, these studies are unable to examine variation across investors and control for important individual characteristics such as investment strategies and financial literacy that could influence the relation between financial disclosure quality and individuals' shareholdings.

\footnotetext{
${ }^{3}$ Campbell et al. $(2009,74)$ argue that the "most efficient way to predict institutional ownership is to exploit the information in the full range of trade sizes, not ignoring certain trade sizes or imposing restrictions on the way that trading volume information is utilized." Moreover, their findings suggest that trades under $\$ 2,000$ and over $\$ 30,000$ generally reveal institutional rather than individual trading activity. These findings appears to be more pronounced in the past ten years which is consistent with Barber, Odean, and Zhu (2009), using data from the 1983 to 2001 , who find evidence indicating that small trades, at that time, were still a reasonable proxy for individuals' trades.
} 
Other recent research relating to individual investors uses online message board activity, trades on alternative stock exchanges, and survey data in an attempt to measure how individuals use and respond to financial reporting information. In analyzing online message board discussions, Lerman (2010) finds that discussion activity is significantly elevated around earnings releases, suggesting that individual investors pay attention to financial reporting information. Similar to the trade-size cutoff studies, it is unclear as to whether the message board posts are indeed made by individuals and not by institutional investors. ${ }^{4}$ Also using a unique setting, Brüggemann, Daske, Homburg, and Pope $(2009,2)$ examine trades from the Open Market at Frankfurt Stock Exchange, "an unofficial trading segment designed for German individual investors to trade foreign (i.e., non-German) stocks," as a proxy for individual investors' response to the global IFRS adoption. ${ }^{5}$ They find that stocks experience an increase in their Open Market trading activity following the mandatory adoption of IFRS. Lastly, using surveys of individual investors, Cohen, Holder-Webb, Wood, and Nath (2010), find that individual investors are most concerned with information specific to economic performance, followed by governance, and then by corporate social responsibility activities. Moreover, also using survey data, Elliott, Hodge, and Jackson (2008), find that investor experience appears to mitigate the negative association between investors' returns and their use of unfiltered information.

The final set of empirical studies relating to individual investors uses proprietary trading records of individuals to obtain a direct measure of individuals' trading activity and thus,

\footnotetext{
${ }^{4}$ Individual investors are not the only market participants following online blogs and message boards. In his book the Big Short (Lewis 2010), Michael Lewis tells the story of 32 year-old Dr. Mike Burry, who in 2004 spotted the subprime bubble, set up a hedge fund and then approached the investment banks to sell credit-default swaps on subprime-mortgage bonds. In this account, Dr. Burry explains that before he became well-known in the investment industry, he noticed that institutional investors were tracking and posting comments on his online blog dedicated to individual investors.

${ }^{5}$ The Open Market (Freiverkehr) is an unofficial market segment offering an appropriate first entry point for small or recently founded companies.
} 
overcome the foregoing measurement and proxy concerns noted above. Using such trading records, Hirshleifer, Myers, Myers, and Teoh (2008), Kaniel, Liu, Saar, and Titman (2008), and Taylor (2009) investigate whether individual investors appear to contribute to the post-earnings announcement drift (PEAD). Hirshleifer et al. (2008) and Taylor (2009) examine individual investor trading data of 78,000 households from a major U.S. discount brokerage firm which are also used in my analyses (see Section 1.3 for more details).

These studies find conflicting evidence concerning whether individuals contribute to the PEAD. The difference between the conclusions of these two studies arises from a focus on the net amount of individual investors' trades (Hirshleifer et al. 2008) versus the classification as to whether individual investors' trades were contrarian (Taylor 2009). Kaniel et al. (2008), using proprietary NYSE trading data of individual investors, find that individuals who trade before the earnings announcement appear to trade in accordance with future abnormal returns. Moreover, Taylor (2010) shows that individuals' trading activity significantly increases around earnings announcements and that these trades experience greater losses than non-earnings announcement trades. ${ }^{6}$ While the data used in Kaniel et al. (2008) represent the majority of trades made by individuals on the NYSE and hence, have extensive breadth, an advantage of my brokerage data is their depth-containing shareholding positions and information concerning individual characteristics, which I benefit from in my analyses.

\subsubsection{Hypotheses Development}

The hypotheses examined in this study center around how individual investors' holdings vary with the quality of firms' financial disclosures, and stem from the following underlying

\footnotetext{
${ }^{6}$ Hirshleifer et al. (2008), Kaniel et al. (2008), and Taylor (2009, 2010) all attempt to understand how individual investors respond to information in earnings announcements, or more specifically, to the net earnings-per-share (EPS) figure. In contrast, in this study, I attempt to understand whether individual investors use the supplementary financial disclosure information, beyond the net EPS figure, that accompanies the financial statements.
} 
premises: (1) demand for a firm's securities decreases in the extent of adverse selection; (2) adverse selection is a function of a firm's financial disclosure; and, (3) investors possess different levels of private information. The extant empirical literature generally finds that uninformed investors prefer better financial disclosures as increased transparency reduces their informational disadvantage (e.g., Merton 1987; Easley and O’Hara 2004). Moreover, several analytical papers predict that a security's liquidity, and hence its trading demand, is increasing in public disclosures as disclosures reduce future adverse selection concerns for investors (e.g., Diamond and Verrecchia 1991; Kim and Verrecchia 1994). ${ }^{7}$ Given that individual investors are generally less informed than other investors, this relation could potentially be more pronounced for individual investors. Hence, higher quality financial disclosures provide some assurance to individual investors that they are less uninformed relative to other investors.

Consistent with the SEC's disclosure findings and the extant literature, I argue that individual investors invest in companies with better quality financial disclosures as such disclosures reduce the extent of adverse selection. My first hypothesis (in alternative form) is:

\footnotetext{
${ }^{7}$ Diamond and Verrecchia (1991) develop a model which shows that revealing private information increases liquidity and hence, investor demand. Their model includes a firm that can disclose any or all of its information, and two traders with limited risk aversion that may either face future liquidity shocks with a probability of one-half, forcing them to trade a random amount, or alternatively, that may receive private information in the future with a probability of one-half. Also included in this model are a group of limited risk bearing market makers that do not face any liquidity shocks or receive any private information; although they do observe all public information and the order imbalance for the trading security. Lastly, the model includes a small group of price-taking and risk-averse competitive traders who do not observe the security's order flow. At date 1, each trader anticipates with one-half probability that $\mathrm{s} /$ he will be the trader needing liquidity versus receiving private information. At date 2 , the traders discover which trader requires liquidity and which trader receives private information and at date 3 , the price per share value of the firm is revealed. Moreover, on date 2, the firm acquires information and can decide to disclose some or all of it to the public before trading at date 2. In turn, the disclosure of private information by the firm increases the liquidity of the market at date 2. Diamond and Verrecchia (1991) show that within this framework, the two traders' demand for the firm's security at date 1 is increasing in the anticipated future liquidity of the market given their anticipated liquidity needs. Hence, the traders' demand and in turn, holdings of the firm's security are increasing in the extent of information disclosed by the firm.
} 


\section{H1: Individual investors' holdings are positively related to the quality of firms' financial}

disclosures.

The foregoing hypothesis pertains to how individuals in general use financial disclosure and the following hypothesis attempts to explore variation among individuals in their use of financial disclosure. Bloomfield $(2010,1)$ argues that the average finance researcher:

"sees financial settings populated not by the error-prone and emotional Homo sapiens, but by the awesome Homo economicus. The latter makes perfectly rational decisions, applies unlimited processing power to any available information, and holds preferences well described by standard expected utility theory. Anyone with a spouse, child, boss, or modicum of self-insight knows that the assumption of Homo economicus is false."

Psychologists on average have a much less flattering view of individuals than accounting and finance researchers. For example, they believe that individuals are error prone, not fully rational, and overconfident about many of their own abilities. The psychology literature finds that individuals' self-assessed judgments of their skills are often much higher than their actual skilllevel (e.g., Einhorn and Hogarth 1978; Gigerenzer, Hoffrage, and Kleinbölting 1991). Several studies document the overconfidence of individuals and professionals. Specifically, these studies find that analysts and investors exhibit systematic overconfidence in their earnings forecasts, (e.g., Easterwood and Nutt 1999; Hales 2007; Libby, Hunton, Tan, and Seybert 2008), that audit partners demonstrate significant overconfidence in the ability of their subordinates to detect misstatements (Messier, Owhoso, and Rakovski 2008), and that CEO overconfidence contributes to corporate investment distortions, suboptimal takeover decisions, and to underinvestment in information production (e.g., Malmendier and Tate 2005, 2008; Goel and Thakor 2008). 
Specific to individual investors, research suggests that overconfident individual traders place too much weight on private versus public information and underreact to highly relevant information (e.g., Daniel et al. 1998; Odean 1998). The underlying "rationale for the assumption of overconfidence is that the investor has a personal attachment to her own signal" (Daniel et al. 1998, 1846) and therefore, overestimates the precision of this signal. Bloomfield, Libby, and Nelson (1999), in an experimental setting, find that the proposed practice of providing additional information to institutions could harm overconfident individuals unless they are aware of their information disadvantage. Moreover, Grinblatt and Keloharju (2009) find that overconfident individuals are those most prone to sensation-seeking trading.

A common theme of the aforementioned findings is that overconfidence leads to an underestimation of risk. If overconfident individuals underestimate the extent of adverse selection, in addition to placing too much weight on their private versus public information, then it is likely that they will place less weight on the importance of higher quality financial disclosures. Following this rationale, I predict that overconfident individual investors place a lower weighting of their portfolio in firms with higher quality financial disclosures. ${ }^{8}$ Thus, my second hypothesis (in alternative form) is:

H2: The positive relation between individual investors' holdings and the quality of a firm's financial disclosure is less pronounced for overconfident individuals.

\footnotetext{
${ }^{8}$ The same result can arise among rational investors with heterogeneity in the precision of their private signals. Specifically, if individuals differ in the precision of their private information, then rational individuals who are informed will put more weight on their private signal and hence, will be less likely to hold firms with higher quality financial disclosures. However, this alternative is unlikely as overconfident individuals, in this dataset, are found to earn lower investment returns (e.g., Barber and Odean 2000, 2001) ruling out the notion that these individuals are informed.
} 
Not only is there limited research comparing how different individuals use financial disclosures, there is also limited empirical research, using actual trading records, comparing how institutions and individuals differ in their use of financial disclosure. Prior research generally regards institutional investors as sophisticated investors (e.g., Bartov, Radhakrishnan, and Krinsky 2000; D’Souza, Ramesh, and Shen 2010) who have lower information processing costs than other market participants, and documents that institutions develop and trade on their own private information (e.g., Ke and Petroni 2004; Bushee and Goodman 2007; Ali et al. 2008). Although institutions are attracted to higher financial disclosure quality (e.g., Healy et al. 1999; Bushee and Noe 2000), they also benefit from poorer information environments in which they are able to generate and obtain private signals. In contrast, individuals are generally regarded as less sophisticated and uninformed investors (e.g., Barber and Odean 2000; De Franco et al. 2007; Kaniel et al. 2008; Taylor 2009; Koonce, Williamson, and Winchel 2010) who do not have the same level of expertise and resources as institutions to develop and acquire private information. Therefore, without the ability to generate and acquire private information, individual investors may rely relatively more on financial disclosures to narrow their information acquisition disadvantage, and in turn, reduce their information risk. Taking these relations together, I expect that individual investors will place a greater weighting of their portfolio in firms with higher quality disclosures relative to institutional investors.

Consistent with the foregoing rationale, Kim (1993) proposes that investors with better private information and lower information acquisition costs desire less public disclosure than uninformed investors. In Kim's model, investors are assumed to have different risk tolerances and information acquisition costs and thus, those investors with higher risk tolerances and lower information acquisition costs acquire more private information. In turn, increased disclosure 
weakens the information advantage for those with private information. If we combine this reasoning with the findings that institutional investors are generally informed and individual investors are less informed, the predictions of Kim (1993) also support the notion that individual investors' demand for higher quality disclosures will be greater relative to that of institutional investors. In line with the aforementioned arguments, my third and final hypothesis (in alternative form) is:

H3: Individual investors place a greater weighting of their portfolios in firms with higher financial disclosure quality relative to institutional investors.

Alternatively, it is also possible that higher quality financial disclosures trigger the generation of private information by sophisticated information processors (e.g., Kim and Verrecchia 1994, 1997), increasing the information gap between institutional and individual investors. ${ }^{9}$ Thus, it is ultimately an empirical question as to whether institutional or individual investors place a greater importance on higher quality financial disclosures.

\subsection{SAMPLE, METHODS, AND VARIABLE MEASUREMENT}

\subsubsection{Sample}

The brokerage dataset used in this study includes the trades and portfolio positions of individual investors at a major U.S. discount-brokerage firm for the period between January 1991 and December 1996. These brokerage data were obtained from Terrance Odean of the

\footnotetext{
${ }^{9}$ Under this scenario, institutional investors would prefer more public information and hence, place a greater weighting of their portfolios in firms with higher disclosure quality relative to individual investors. The models in Kim and Verrecchia $(1994,1997)$ rely on the underlying rationale that in the absence of accounting disclosures "there are no opportunities for traders capable of informed judgements to exploit their ability to process public information" as all traders have the same information set before the disclosure (Kim and Verrecchia 1994, 42). However, the assumption made in Kim (1993) that traders are endowed with their own private information before disclosures are made more likely reflects the circumstances in my setting.
} 
University of California at Berkeley. The brokerage data contain a sample of 78,000 households, representing 158,034 separate individual accounts, selected from a total client base of 1.25 million households. The sample selection, made by the brokerage firm, was stratified based on whether the household was labeled by the brokerage house as a general household $(60,000)$, an active-trader household $(6,000)$, or an affluent household $(12,000)$ to keep a similar household composition as in the full brokerage population. The brokerage firm denotes a household to be active if it makes more than 48 trades in any year, affluent if it has more than $\$ 100,000$ in equity at any point in time, and general for all remaining households. ${ }^{10}$

A possible concern with using portfolio records from one discount broker is whether these records are representative of the portfolios of the whole individual investor population. Previous studies provide some support for the validity of these brokerage data as they find that trades in the dataset are correlated with information reported on individuals' tax returns and with trades of other brokerage firms (e.g., Ivković, Poterba, and Weisbenner 2005; Barber and Odean 2008).

The empirical tests in this study are conducted at the individual account level to allow for heterogeneity across individual investors and to explore differences across individuals in their use of financial disclosure. The final samples reflect the intersection of the individual account level data with firm or market-level data from AIMR disclosure rankings, COMPUSTAT, CRSP, Ken French's website, I/B/E/S, Thomson-Reuters Institutional Holdings (13F), and 10-K filings, resulting in a dataset with account-firm-year observations.

Table 1 provides details concerning the sample selection. The annual report and the disclosure score samples start with 95,107 and 272,432 account-firm-year observations,

\footnotetext{
${ }^{10}$ For more information concerning the brokerage data, see Barber and Odean (2000), Kumar and Lee
} (2006), Hirshleifer et al. (2008), and Taylor (2009). 
respectively, with shareholdings and financial disclosure data. After imposing the necessary requirements to calculate control variables using COMPUSTAT and CRSP data, I obtain an annual report sample of 91,228 account-firm-year observations with 1,266 separate firm-year observations, and a disclosure score sample of 249,888 account-firm-year observations with 1,084 separate firm-year observations. The samples differ in account-firm-year observations as the annual report readability and length measures are only available beginning in 1994, the year the electronic filing of financial statements commenced with the SEC.

\subsubsection{Methods and Variable Measurement}

The analyses in this study focus on the relation between individuals' holdings (HOLDINGS), the dependent variable, and financial disclosure quality (DISCLOSURE), the main variable of interest. The following regression model tests H1's prediction of a positive relation between individual investors' holdings and the quality of firms' financial disclosure:

$$
\begin{aligned}
& \text { HOLDINGS }_{i j t+1}=\beta_{0}+\beta_{1} \text { DISCLOSURE }_{j t}+\beta_{2} \text { EQUITY }_{i j t+1}+\beta_{3} \text { LOGASSETS }_{j t} \\
& +\beta_{4} M B_{j t}+\beta_{5} S \& P 500_{j t}+\beta_{6} A_{N A L Y S T}+\beta_{7} S H A R E H O L D E R S_{j t} \\
& +\beta_{8} R O A_{j t}+\beta_{9} F F_{-} B E T A_{j t+1}+\beta_{10} R E T_{-} V O L_{j t}+\beta_{11} E A R N_{-} V O L_{j t} \\
& +\beta_{12} N_{B S E G_{j t}}+\beta_{13} N_{S S E G_{j t}}+\beta_{14} N_{I T E M S}+\beta_{15} L O S S_{j t} \\
& + \text { INDUSTRY_FE }+ \text { YEAR_FE }+\varepsilon_{i j t+1}
\end{aligned}
$$

For full variable definitions see Appendix A. HOLDINGS is individual $i$ 's one-year monthly averaged holdings of firm $j$ ending thirteen months after firm $j$ 's fiscal year-end as a percentage of individual $i$ 's total holdings. ${ }^{11}$ I measure the individual's holdings in the year following the fiscal year-end to incorporate the lead-lag relation between financial disclosure and individuals'

\footnotetext{
${ }^{11}$ For example, suppose IBM has a December 31 year-end in year $t$. I would calculate the individuals' average holdings in IBM from February 1 year $t+1$ to January 31 year $t+2$ as a percentage of her total average equity holdings during this same period.
} 
shareholdings. I find that the main inferences are robust to an alternative dependent variable, discussed in the Alternative Holdings and Overconfidence Measures subsection of the Additional Analyses (Section 1.5). ${ }^{12}$

The three financial disclosure quality measures (DISCLOSURE) used in this study are: (1) FOG_INV, (2) LENGTH_INV, and (3) AIMR_SCORE. The Fog Index, a computational linguistics index developed by Robert Gunning, measures the readability of English writing. The Fog Index grades complexity using a combination of the number of words per sentence and the number of syllables per word, indicating the number of years of formal education required to read and understand the text. Following Li (2008), FOG_INV is the Fog Index of firm j's 10-K filing calculated as the $(0.4 \mathrm{x}$ (average words per sentence + percentage of complex words). Also consistent with $\mathrm{Li}$ (2008), I measure the length of the annual report, LENGTH_INV, as the natural logarithm of the word count of firm $j$ 's $10-\mathrm{K}$ filing. I use FOG_INV and LENGTH_INV as the first two measures of financial disclosure quality, reflecting disclosure accessibility, as according to the SEC (2007), readability and excessive length of financial statements are two significant disclosure concerns among individual investors. I multiply both FOG_INV and LENGTH_INV by -1 so that larger values imply higher financial disclosure quality.

The last measure of financial disclosure quality is AIMR_SCORE, which is the industryadjusted Association of Investment Management Research (AIMR) ranked disclosure score. ${ }^{13}$ Used extensively in prior research (e.g., Lang and Lundholm 1996; Healy et al. 1999), the AIMR scores represent analysts' assessment of the informativeness of the firms' overall disclosure

\footnotetext{
${ }^{12}$ Using actual holdings reveals the relation between financial disclosure and individual investors' holdings, and not just individuals' trades surrounding reporting announcements. Thus, I can examine the pervasive effects of financial disclosure on individuals' investment decisions. Moreover, holdings better reflect investors' demand for a stock rather than their trades as trading activity has been shown to more reflect liquidity (e.g., Kyle 1985), transaction costs (e.g., Bhushan 1994), and changes in expectations (e.g., Beaver 1968; Garfinkel 2009). Hence, examining holdings rather than trades is more appropriate for identifying whether investors demand stocks with higher quality financial disclosures.

${ }^{13}$ In 2004, the AIMR changed its name to the CFA Institute.
} 
practices, with higher AIMR scores representing more informative and transparent financial disclosures. As higher values of the three disclosure variables represent superior financial disclosures, a positive and statistically significant $\beta_{l}$ provides support for $\mathrm{H} 1$.

Barber and Odean (2001) provide evidence that personal characteristics can explain differential trading patterns among individuals and hence, I include the variable EQUITY to control for personal characteristics that could influence individuals' portfolio preferences. In addition, I include LOGASSETS, MTB, S\&P500, ANALYST, SHAREHOLDERS, ROA, and $F F \_B E T A$, to control for important firm characteristics that are likely to affect individual investors' shareholdings. Moreover, following Li (2008), I include the following known determinants of financial disclosure attributes: RET_VOL, EARN_VOL, NBSEG, NGSEG, NITEMS, and LOSS, that could also affect individuals' investment decisions.

The second hypothesis concerns whether the positive relation between individual investors' holdings and the quality of firms' financial disclosure is less pronounced for overconfident individuals. In line with the prior literature which argues that overconfidence drives excessive trading of individuals (e.g., Odean 1998; Barber and Odean 2000; Barber and Odean 2001; Deaves et al. 2006; Statman, Thorley, and Vorkink 2006), I use individuals' trading frequency as a proxy for investor overconfidence. Specifically, I measure individual overconfidence, OVERCONFIDENCE, as the natural logarithm of trades made by individual $i$ during the year in any stock. I obtain comfort using excessive trading as proxy for overconfidence as prior studies using this dataset (e.g., Barber and Odean 2000, 2001) find that excessive trading is associated with lower investment returns. In the Additional Analyses (Section 1.5), I show that results also hold using two alternative overconfidence measures. Adding OVERCONFIDENCE to Equation (1) with an interaction term between 
OVERCONFIDENCE and DISCLOSURE, I obtain the following specification to test $\mathrm{H} 2$ :

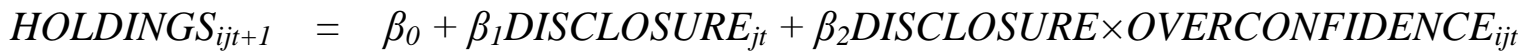

$$
\begin{aligned}
& +\beta_{3} \text { OVERCONFIDENCE } E_{i j t+1}+\beta_{4} \text { EQUITY }_{i j t+1}+\beta_{5} \text { LOGASSETS }_{j t}
\end{aligned}
$$

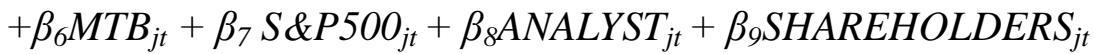

$$
\begin{aligned}
& +\beta_{10} R O A_{j t}+\beta_{11} F F_{-} B E T A_{j t+1}+\beta_{12} R E T_{-} V O L_{j t}+\beta_{13} E A R N_{-} V O L_{j t} \\
& +\beta_{14} N B S E G_{j t}+\beta_{15} N G S E G_{j t}+\beta_{16} N I T E M S_{j t}+\beta_{17} L O S S_{j t} \\
& + \text { INDUSTRY_FE }+ \text { YEAR_FE }+\varepsilon_{i j t+1}
\end{aligned}
$$

A negative and significant coefficient on $\beta_{2}$ provides support for $\mathrm{H} 2$; meaning that individuals are likely to follow companies with higher financial disclosure quality but this relation is less evident for overconfident individuals. Consistent with H2, I still expect to observe a significantly net positive coefficient on the joint test of $\beta_{1}$ and $\beta_{2}$, indicating that overconfident individuals value disclosure but just less than other individuals.

$\mathrm{H} 3$ predicts that individual investors will attach a greater weighting to higher quality financial disclosures relative to institutional investors. For this analysis, I retain the individual investor data in an account-firm-year structure and augment it with institutional investor holdings which are also in an equivalent account-firm-year structure. ${ }^{14}$ Using this joint individualinstitutional dataset, I employ the following regression specification to test $\mathrm{H} 3$ :

\footnotetext{
${ }^{14}$ For example, for each institutional investor I calculate their HOLDINGS values, the percentage of the institution's portfolio that is invested in firm $j$ in fiscal year $t+1$. I then treat this observation like an individual account number observation with the exception that it is identified by the variable INSTITUTION, taking a value of "1" for institutional investors. This yields a total number of 266,696 (91,228 individual and 175,468 institutional) and 539,377 (249,888 individual and 289,489 institutional) observations, respectively, for the annual report and disclosure score samples.
} 


$$
\begin{aligned}
& \text { HOLDINGS }_{i j t+1}=\beta_{0}+\beta_{1} \text { DISCLOSURE }_{j t}+\beta_{2}{\text { DISCLOSURE } \times \text { INSTITUTION }_{i j t}} \\
& +\beta_{3} \text { INSTITUTION }_{i j}+\beta_{4} \text { LOGASSETS }_{j t}+\beta_{5} \text { MTB }_{j t}+\beta_{6} S \&{\text { P } 50 O_{j t}} \\
& +\beta_{7} A_{N A L Y S T}+\beta_{8} S H A R E H O L D E R S_{j t}+\beta_{9} R O A_{j t} \\
& +\beta_{10} F F \_B E T A_{j t+1}+\beta_{11} R E T_{-} V O L_{j t}+B_{12} E A R N_{-} V O L_{j t} \\
& +\beta_{13} N B S E G_{j t}+\beta_{14} N G S E G_{j t}+\beta_{15} N I T E M S_{j t}+\beta_{16} L O S S_{j t} \\
& + \text { INDUSTRY_FE }+ \text { YEAR_FE }+\varepsilon_{i j t+1}
\end{aligned}
$$

The main coefficient of interest is $\beta_{2}$, reflecting the interaction between DISCLOSURE and INSTITUTION, an indicator variable equal to " 1 " if the holdings belongs to an institution and to " 0 " if the holdings belong to an individual. A negative $\beta_{2}$ coefficient that is significantly different from zero indicates support for $\mathrm{H} 3$.

\subsection{RESULTS}

\subsubsection{Descriptive Statistics and Correlations}

Table 2, Panel A presents the descriptive statistics for the annual report and disclosure score samples. The mean and median values for HOLDINGS are 24 percent and 10 percent, respectively, for the annual report sample, and 28 percent and 14 percent for the disclosure score sample. Overall, the descriptive statistics for the control variables are fairly similar across the two samples.

Panels B and C of Table 2 show the correlation matrices for the annual report readability and length, and disclosure score samples. The correlation between $F O G \_I N V$ and LENGTH_INV is 0.35 and statistically significant $(p<0.01)$. Moreover, in a sample of 21,632 account-firm-year observations that contain data for $F O G \_I N V, \quad L E N G T H \_I N V$, and AIMR_SCORE, the correlations (untabulated) between $F O G \_I N V$ and $A I M R \_S C O R E$, and $L E N G T H \_I N V$ and 
AIMR_SCORE are 0.02 and 0.08 , respectively, and significant $(p<0.01)$. Thus, although FOG_INV and $L E N G T H \_I N V$ are positively correlated with $A I M R \_S C O R E$, it is not surprising the correlations are relatively low given that $F O G_{-} I N V$ and $L E N G T H_{-} I N V$ reflect disclosure accessibility while AIMR_SCORE more reflects disclosure transparency. More importantly and consistent with $\mathrm{H} 1$, the correlations between $H O L D I N G S$ and each of the financial disclosure quality measures are all positive and statistically significant $(p<0.01)$, indicating that that there is a positive relation between individual investors' holdings and the quality of firms' financial disclosures.

\subsubsection{Multivariate Analyses}

Table 3 provides regression evidence relating to H1 using FOG_INV, LENGTH_INV, and AIMR_SCORE as financial disclosure quality measures. Columns (I), (III), and (V) each include those variables known to influence shareholdings and the remaining columns include additional variables that could potentially confound the relation between financial disclosure quality and individuals' shareholdings. I find support for $\mathrm{H} 1$ across all three financial disclosure measures as all the coefficients on FOG_INV, LENGTH_INV, and AIMR_SCORE are positive and statistically significant $(p<0.01)$. Specifically, in Columns (I) and (II), the estimated coefficients on FOG_INV, with and without the additional disclosure controls, are 0.005, and in Columns (III) and (IV), the coefficients on LENGTH_INV, with and without the additional disclosure controls, are 0.008 and 0.006, respectively. Moreover, in Columns (V) and (VI), the coefficients on AIMR_SCORE are 0.024 and 0.022 , respectively. To provide some perspective on the economic significance, on average, these results imply that a one-standard-deviation increase in financial disclosure quality corresponds to an approximate increase in individuals' holdings of two to three percent. EQUITY is negative and significant $(p<0.01)$ in all regressions, indicating 
that wealthier individuals are more likely to hold a greater number of stocks. Examining the other control variables across the two samples and various regressions, it appears that individual investors invest a greater percentage of their portfolios in larger (LOGASSETS, S\&P500), higher market-to-book $(M T B)$, low beta $\left(F F_{-} B E T A\right)$, and more profitable firms $(R O A, L O S S)$ that are less financially complicated (NITEMS). ${ }^{15}$

Given that there is little overlap between the annual report sample and the disclosure score sample, it is difficult to compare all three disclosure measures. However, using the annual report sample of 91,288 account-firm-year observations, I simultaneously include FOG_INV and LENGTH_INV in Column (VII) and find that the coefficients on both variables are positive and significant $(\mathrm{p}<0.01)$. Specifically, the coefficients on $F O G \_I N V$ and $L E N G T H \_I N V$ are 0.004 and 0.006 , respectively, indicating that a one-standard-deviation increase in FOG_INV corresponds to an increase of approximately two percent in the individuals' holdings and that a one-standard-deviation increase in $L E N G T H \_I N V$ corresponds to an increase of approximately one percent in the individuals' holdings. Thus, while annual report readability and excessive length (disclosure accessibility) are both important to individual investors, annual report readability appears to have a slightly greater economic effect on individuals' investment decisions than does annual report excessive length. ${ }^{16}$ In an unreported analysis, I find a positive and significant coefficient on an interaction between $F O G \_I N V$ and $L E N G T H \_I N V$, indicating

\footnotetext{
${ }^{15}$ The underlying assumption with NITEMS as a proxy for financial complexity is that the more financially complex firms, on average, need to report more items in their financial statements.

${ }^{16} \mathrm{I}$ follow the previous literature in analyzing individuals' non-zero investment activity (e.g., Barber and Odean 2000, 2001; Hirshleifer et al. 2008; Taylor 2009, 2010). However, to examine whether the exclusion of zero investments impact my inferences, I run Tobit regressions of Equation (1) where I only examine the ten firms in my sample with the highest portfolio holdings, but for these firms I include all individuals' holdings in the analysis irrespective of whether they are positive or zero. I only examine a subsample of ten firms as this procedure creates samples of approximately 100,000 observations for every firm-year. I find that the inferences are robust to this alternative analysis.
} 
that individuals invest even more in firms that have both readable and concise disclosuressupporting the notion that the two disclosure attributes are complements and not substitutes.

Table 4 tests H2's prediction that the foregoing positive relation between individual investors' holdings and the quality of firms' financial disclosures is less pronounced for overconfident individuals. ${ }^{17}$ Consistent with Table 3, the coefficients on FOG_INV (Column I), LENGTH_INV (Column III), and AIMR_SCORE (Column V) are all still positive and statistically significant $(p<0.01)$ after including OVERCONFIDENCE. The main variables of interest in this test are the interactions between each financial disclosure measure and OVERCONFIDENCE. All interaction terms are negative and significant at the one-percent level. Specifically the coefficients on FOG_INV $\times$ OVERCONFIDENCE, LENGTH_INV $\times$ OVERCONFIDENCE, and AIMR_SCORE $\times$ OVERCONFIDENCE are $-0.003,-0.005$, and -0.027 , respectively. In addition, joint tests of the main effect and the interaction term (untabulated) are all positive and significant for all three disclosure measures, indicating that overconfident individuals still use disclosures but significantly less than other individuals. Overall, these findings support H2's prediction that the relation between individuals' holdings and the quality of a financial disclosure is less pronounced for overconfident individuals. ${ }^{18}$

Table 5 examines whether individuals and institutions differ in their use of financial disclosure. Columns (I) to (III) present the analyses for only institutional investors. The coefficients on $F O G \_I N V$ and $L E N G T H \_I N V$ in Columns (I) and (II), respectively, are positive and significant $(p<0.05)$, and the coefficient on AIMR_SCORE in Column (III) is positive and weakly significant $(p<0.10)$. Overall, these findings are consistent with the previous literature

\footnotetext{
${ }^{17}$ Approximately 10,000 individual investors are classified as overconfident.

${ }^{18}$ To the extent that incurring losses while excessively trading does not capture overconfidence, the overconfidence results can be alternatively interpreted as follows: individuals who trade frequently invest less in firms with more accessible and transparent disclosures than those individuals who trade infrequently.
} 
suggesting that institutional investors generally value higher disclosure quality. Columns (IV) to (VI) include interaction terms between the respective financial disclosure measure and INSTITUTION. The coefficients on the main effects for the three disclosure measures, $F O G \_I N V, L E N G T H \_I N V$, and $A I M R \_S C O R E$ are all positive and significant $(p<0.01)$. More importantly, in Columns (IV) to (VI) the interaction terms FOG_INV $\times$ INSTITUTION, LENGTH_INV $\times$ INSTITUTION, and AIMR_SCORE $\times$ INSTITUTION are all negative. The FOG_INV $\times$ INSTITUTION and AIMR_SCORE $\times I N S T I T U T I O N$ terms are significantly negative $(p<0.01)$, although the LENGTH_INV $\times$ INSTITUTION term is insignificantly different from zero $(t=-1.23 ; p=0.22) .{ }^{19}$ These results provide evidence suggesting that institutions attach less importance to more readable and informative financial disclosures than do individual investors in relation to their portfolio weightings.

\subsection{ADDITIONAL ANALYSES}

\subsubsection{Investment Strategy and Financial Literacy}

To capture the richness of the individual investor data and to further explore crosssectional variation among individuals, I examine whether individuals' use of disclosure varies with investment strategy and financial literacy. ${ }^{20}$ The type of investment strategy could impact how individuals' use financial disclosures. Specifically, I examine whether speculative investors, whose investment strategies rely on conjecture rather than knowledge, will be less partial to firms with more accessible and transparent disclosures than growth, income, and conservative investors. I measure speculative investors, SPECULATIVE, as "1" if the individual reported their

\footnotetext{
19 Inferences are similar when comparing the financial disclosure coefficients from separate regressions of individuals and institutions using the procedure outlined by Clogg, Petkova, and Haritou (1995).

${ }^{20}$ These analyses are performed in sub-samples were data are available.
} 
investment strategy upon account setup as "speculation" and " 0 " otherwise. ${ }^{21}$ The results, reported in Table 6, show that speculative investors invest less in firms with accessible and transparent disclosures than the average investor as the interaction terms are all negative and significant at the five or ten percent level. More specifically, an F-test of the main and interaction effects equaling zero suggests that speculative investors do not exhibit a preference for firms with accessible and transparent disclosures - consistent with the notion that speculation would be most appropriate in more opaque environments.

It is not fully obvious whether financially literate individuals would exhibit a preference for firms with accessible and transparent financial disclosures. It is more palpable that due to their lower information processing costs, financially literate individuals would prefer less accessible disclosures but the predictions on transparent disclosures are less clear. For example, financially literate individuals could prefer opaque firms as they can navigate best in such environments or they could prefer transparent firms as they provide more opportunities to process and analyze information. I measure financial literacy, FIN_LITERACY, as "1" if the individual is employed as a professional and " 0 " otherwise. The rationale for this proxy is that professionals (e.g., lawyers, accountants, actuaries, businessmen, doctors) will, on average, be more financially literate than nonprofessionals due to the nature of their work and training. Table 7 shows that financially literate individuals, approximately a third of this subsample, are less partial to firms with accessible and transparent disclosures. In addition, an F-test of the main and interaction effects indicates that financial literate investors do not display a preference for accessible and transparent disclosures, suggesting that financially literate individuals prefer more opaque firms to exploit their competitive advantages.

\footnotetext{
${ }^{21}$ Speculative investors account for approximately seven percent of all individuals.
} 


\subsubsection{Excess Returns Analyses}

As a supplement to the main results of this study, I examine whether individual investors' excess returns are associated with higher financial disclosure quality as better financial disclosures could possibly reduce individual investors' informational disadvantage relative to more sophisticated investors. I measure excess returns, $A B \_R E T U R N S$, using monthly positions following Barber and Odean (2000), as individual $i$ 's dollar return of firm $j$, net of trading commissions, minus the dollar return on a value-weighted index of NYSE/AMEX/NASDAQ stocks beginning one month to thirteen months after firm $j$ 's fiscal year-end, scaled by individual $i$ 's averaged holdings of firm $j$ during this period. Employing Equation (1) but using excess returns as the dependent variable and including Carhart's (1997) four risks factors (calculated for each firm) as additional controls, I find that individual investors' excess returns are increasing in all three financial disclosure measures and that all disclosure coefficients are significant $(p<$ 0.05)—see Table 8. In terms of economic significance, I find that a one-standard-deviation increase in disclosure quality corresponds to an approximate increase of one percent per annum in individual investors' excess stock returns. These results suggest that more accessible and transparent disclosures reduce individuals' information disadvantage and hence, their losses in firms with such disclosure attributes.

\subsubsection{Information Environment}

An important tool used by investors is fundamental analysis. The next test examines whether individuals use of financial disclosure varies with respect to the level of certainty, or 
uncertainty, conveyed through the firms' key fundamental signals. ${ }^{22}$ Following Piotroski (2000), I measure the firm's financial strength, FUNDAMENTAL, using the F-Score, which is the aggregate score of nine different signals assessing the firm's profitability, financial liquidity, and operating efficiency. ${ }^{23}$ Table 9 reports the results of this analysis and shows that when firms' fundamentals are weaker (i.e., more uncertainty for investors), individuals rely more on accessible and transparent disclosures to reduce their uncertainty, as the interaction terms are positive and significant for both $F O G \_I N V$ and $A I M R \_S C O R E$ at the one percent level.

As analysts are information intermediaries for investors and can reduce information asymmetry (e.g., Frankel and Li 2004; Lehavy, Li, and Merkley 2010), I also examine whether the positive relation between individual investors' holdings and financial disclosure quality is affected by analyst following. I find in untabulated analyses that the positive relation between individuals' holdings and financial disclosure is less pronounced for firms with analyst following using the LENGTH_INV and AIMR_SCORE measures. In other words, I find evidence suggesting that accessible and transparent disclosures are more important when there is no analyst following.

\subsubsection{Changes Analyses}

To provide some insight on the causal relation between individual investors' shareholdings and financial disclosure quality, and to control for time-invariant omitted variables, following Covrig, DeFond, and Hung (2007) who examine mutual fund holdings, I investigate the lead-lag relation between changes in financial disclosure quality and changes in individual investors' shareholdings using the following changes specification of Equation (1):

\footnotetext{
${ }^{22}$ This analysis is performed in sub-samples were data are available.

${ }^{23}$ For ease of interpretation, I multiply the F-Score by "-1", meaning that higher scores reflect weaker fundamentals.
} 


$$
\begin{aligned}
& \triangle H O L D I N G S_{i j t+1}=\beta_{0}+\beta_{1} \Delta D I S C L O S U R E_{j t}+\beta_{2} \Delta E_{Q U U T Y} \text { IIjt+1 }_{1}+\beta_{3} \Delta \text { LOGASSETS }_{j t} \\
& +\beta_{4} \Delta M T B_{j t}+\beta_{5} \triangle A N A L Y S T_{j t+} \beta_{6} \Delta S H A R E H O L D E R S_{j t} \\
& +\beta_{7} \Delta R O A_{j t+} \beta_{8} \Delta F F_{-} B E T A_{j t+1}+\beta_{9} \Delta R E T_{-} V O L_{j t}+\beta_{10} \Delta E A R N_{-} V O L_{j t} \\
& +\beta_{11} \Delta N B S E G_{j t}+\beta_{12} \Delta N G S E G_{j t}+\beta_{13} \Delta N I T E M S_{j t}+\beta_{14} \Delta L O S S_{j t}+\varepsilon_{i j t+1}
\end{aligned}
$$

The only variable not in Equation (4) that is in Equation (1) is $S \& P 500$ as there were no changes in the S\&P 500 status among firms in the two main samples during the sample period. ${ }^{24}$ Table 10 shows the regression results for Equation (4). The results suggest that increases in financial disclosure quality lead to future increases in individual investors' shareholdings as the coefficients on $\triangle F O G_{-} I N V, \triangle L E N G T H \_I N V, \triangle A I M R \_S C O R E$ are all positive and significant $(p$ $<0.05)$. Again, the samples differ in the number of observations as the annual report readability and length measures are only available beginning in 1994.

\subsubsection{Additional Individual and Firm Level Control Variables}

To supplement the main analyses, I examine whether specific individual investor characteristics, in reduced samples given data availability, could potentially confound the relation between individual investors' investments and financial disclosure quality. To control for diversification, age, experience, and gender effects, I run the main analyses including the following additional controls: STOCKS_HELD, AGE, INVEST_EXP, and FEMALE. STOCKS_HELD is the average number of stocks held by the individual in the year. AGE is the natural logarithm of the individual's age. INVEST_EXP equals "1" if the individual investor upon the setup of their brokerage account assessed their investment experience to be either "good" or "extensive", and "0" otherwise. FEMALE equals "1" if the individual investor is a female, and "0" otherwise.

\footnotetext{
${ }^{24} \triangle H O L D I N G S$ and $\triangle D I S C L O S U R E$ are winsorized at the 1 and 99 percent levels to mitigate the effects of outliers; however, the inferences are similar with or without winsorizing these variables.
} 
Table 11 presents the results for this modified specification of Equation (1). The sample sizes are reduced from the main sample as individual attribute data are not available for all individuals. I find that all main inferences hold controlling for these additional individual characteristics, as the coefficients on $F O G \_I N V, L E N G T H \_I N V$, and AIMR_SCORE are 0.004, 0.009 , and 0.019 , respectively, and are all significant $(p<0.01)$. Although not shown, the inferences also hold when including these variables in the overconfidence analyses. Given that $I N V E S T \_E X P$ is a reasonable proxy for whether an individual is informed and that INVEST_AGE can proxy for the extent of time the individual has available for investment analyses (e.g., retired individuals), these findings provide some comfort that the overconfidence results are not due to alternative explanations (e.g., possession of private information or time availability for investment analyses). I also include interaction terms between the three disclosure measures and the foregoing individual attributes, but fail to find evidence suggesting that these characteristics separately influence how individuals use financial disclosures.

To control for potential firm-level omitted variables in the main analyses, I include several financial disclosure quality determinants (e.g., RET_VOL, EARN_VOL, NBSEG, NGSEG, NITEMS, and LOSS); however, I also find that my main inferences hold when controlling for firm-level disclosure determinants such as firm age (FIRM_AGE) and the extent of special items $(S I)$, and for Fama and French risk factors $\left(F F \_S M B, F F \_H M L\right.$, and CARHART_MOMENTUM) that could potentially influence individuals' shareholdings. Table 12 reports this analysis and shows that the coefficients on FOG_INV,LENGTH_INV, and AIMR_SCORE are all still positive and significant $(p<0.01)$. Specifically, the coefficients on FOG_INV, LENGTH_INV, and AIMR_SCORE are 0.004, 0.007, and 0.024, respectively. 
The main purpose of this paper is to examine how individuals use financial disclosure; however, their use of disclosure could be influenced by the quality of earnings. Hence, I examine whether the primary findings are robust to controlling for performance-adjusted discretionary accruals $(D A)$. Table 13 provides some evidence that individuals invest more of their portfolios in firms with better earnings quality as the coefficients on $D A$ are all negative; however, they are only significant at the ten percent level in Column (I) and at the one percent level in Column (III). Examining the coefficients on the disclosure variables indicates that the relation between individuals' holdings and financial disclosure holds controlling for earnings quality as the coefficients on FOG_INV, LENGTH_INV, and AIMR_SCORE are 0.005, 0.008, and 0.008, respectively, and are all significant $(p<0.01)$.

As the regressions in the main analyses are clustered at the individual level, I also examine whether inferences hold clustering at the firm level. Table 14, which reports these findings for Equation (1), shows that the t-statistics on $F O G \_I N V, L E N G T H \_I N V$, and AIMR_SCORE are 2.05, 1.72, and 2.29, respectively, suggesting similar inferences, albeit a little weaker, to those in the main analyses. Taken together, the foregoing analyses mitigate concerns that omitted individual and firm attributes are confounding the relation between individuals' holdings and financial disclosure quality. See Appendix A for the full variable definitions.

\subsubsection{Alternative Holdings and Overconfidence Measures}

I use alternative proxies to measure both individuals' shareholdings and their overconfidence. First, I measure an individual's shareholdings as the natural logarithm of the total dollar amount invested in a stock $\left(L O G \_H O L D I N G S\right)$ for the individual investor sample. Table 15 reports the results the results for Equation (1) when $L O G \_H O L D I N G S$ is the dependent variable and shows similar results as in the main analyses as the coefficients on FOG_INV, 
LENGTH_INV, and AIMR_SCORE are 0.026, 0.056, and 0.083, respectively, and are all significant $(p<0.01)$. Consistent inferences are obtained for the overconfidence findings, as in the main analyses, when $L O G \_H O L D I N G S$ is employed as the dependent variable.

Second, I measure individuals' overconfidence using the brokerage's firm classification of an active trader: if an individual makes more than 48 trades in any year $\left(B R_{-} O V E R C O N\right)$, as opposed to the natural logarithm of the total trades made in any firm by the individual in the year. In addition, I also measure abnormal overconfidence $\left(A B_{-} O V E R C O N\right)$ as the error term from yearly regressions of OVERCONFIDENCE on characteristics previously shown to be associated with higher individual investor trading activity (LOGEQUITY, FF_BETA, FF_SMB, FF_HML, CARHART_MOMENTUM, and MTB). Columns (I) to (III) of Table 16 report the findings using BR_OVERCON and Columns (IV) to (VI) report the findings using AB_OVERCON. The results indicate that the main inferences hold using these alternative overconfidence measures as all the interaction terms in Columns (I) through (VI) are negative and significant $(p<0.01)$.

\subsubsection{Disclosure Score Sub-Components}

As the AIMR disclosure scores contain annual report (ANNUAL_REPORT), investor relations (INVESTOR_RELATIONS), and other publications (OTHER_PUBLICATIONS) disclosure score breakdowns, in Table 17 I run regressions using each of these disclosure scores in place of the total disclosure score (AIMR_SCORE). I find that the estimated coefficient on each disclosure score is positive and significant $(p<0.01)$. Specifically, the coefficients on ANNUAL_REPORT, INVESTOR_RELATIONS, and OTHER_PUBLICATIONS are 0.036, 0.019, and 0.012 , respectively, suggesting that the annual report disclosure scores appear to be the most important in explaining individuals' shareholdings followed by investor relations disclosure 
scores and lastly, followed by other publications disclosure scores.

\subsubsection{SLS Regressions}

Previous research finds that firms alter their disclosure strategies depending on the type of investors who hold their stock (e.g., Indjejikian 1991, Bushee et al. 2003). I employ a twostage least squares (2SLS) model for the three DISCLOSURE measures to examine whether my results reflect the fact that firms may provide better financial disclosure practices when they have higher individual investor following. I model the first-stage using the disclosure instruments: SALES_GROWTH and OP_MARGIN (see Appendix A for definitions) as used by the previous literature and by Larcker and Rusticus (2010). Table 18 provides the results for the 2SLS regressions for the three financial disclosure measures. The results using the 2SLS regressions are consistent with the main findings as the coefficients on $F O G \_I N V, L E N G T H \_I N V$, and AIMR_SCORE in the second stage are all positive and significant $(p<0.01)$. The partial Fstatistic of all the first-stage regressions are significant $(p<0.01)$ mitigating concerns of a weak instrument problem.

\subsubsection{Household Level}

The main analyses in this study are run at the individual level; however, as investment and risk decisions in families are often made at the household level, I also run the analyses at the household level. Table 19 shows, using Equation (1), that inferences are robust to whether the analyses are performed at the individual or household level as the coefficients on FOG_INV, LENGTH_INV, and AIMR_SCORE are 0.003, 0.006, and 0.016, and significant $(p<0.01)$.

\subsubsection{Alternative Windows}

Given that some individuals turnover their holdings more frequently, I also measure 
individual investors' holdings during a shorter window-from one month to seven months after firm $j$ 's fiscal $t$ year-end. Table 20 shows that all inferences are robust to this shorter holdings period as the coefficients on FOG_INV,LENGTH_INV, and AIMR_SCORE are 0.004, 0.007, and 0.034, respectively, and significant $(p<0.01)$.

\subsubsection{Excluding Equity}

Panels A and B of Table 2 show that the correlation between EQUITY and HOLDINGS is greater than 0.50 . Hence, I examine whether the strong correlation between these variables affect the main inferences. Table 21 presents the regressions for Equation (1), excluding EQUITY, and finds that inferences are similar whether EQUITY is included or excluded from the analyses as the coefficients on $F O G \_I N V, L E N G T H \_I N V$, and $A I M R \_S C O R E$ are all positive and significant $(p<0.01)$.

\subsubsection{EDGAR Filings}

On December 1994, the SEC released No. 33-7122 which made the EDGAR rules final-requiring all domestic registrants to electronically file through the EDGAR system as of January 30, 1995 (SEC 2006). Prior to this date firms could voluntarily file through EDGAR, giving rise to potential selectively concerns for my annual report readability and length analyses as the financial disclosure measures are obtained using electronic 10-Ks filed through EDGAR. To mitigate such selectivity concerns, in Table 22 I rerun the annual report readability and length analyses only using observations subsequent to January 30, 1995 and find that all main inferences hold as the coefficients on $F O G \_I N V$ and $L E N G T H \_I N V$ are 0.005 and 0.011 , respectively, and significant $(p<0.01)$. 


\subsection{CONCLUSION}

Using discount brokerage data of individual investors, I investigate whether individual investors invest more in firms with accessible and transparent financial disclosures. I show that individuals' shareholdings are increasing in firms with readable, concise, and informative financial disclosures; however, this relation is less pronounced for overconfident investors' shareholdings. Moreover, I find that individuals' shareholdings reflect a greater preference for firms with accessible and transparent disclosures relative to institutions' shareholdings. Furthermore, in additional analyses, I show that individuals' use of disclosure varies with their investment strategy and financial literacy, and that the average individuals' investment performance is increasing in accessible and transparent disclosures. This study is the first to empirically relate individuals' investments and returns to the accessibility and transparency of firms' financial disclosures, and to show how individuals' use of financial disclosure varies with their individual characteristics.

Similar to other studies that use proprietary data from a certain time period and a single source, my findings must be interpreted with due regard to their limitations. First, the individual investor trading and shareholdings data used in this study are from the 1990s. Thus, given the changes in financial disclosure standards and the possible advances in individual investor sophistication in recent years, the extent to which the findings would differ from those today is unknown and remains a question for future research. Second, the reader should consider the sample selection criteria imposed on this study by using data from a single brokerage firm when determining how these results might generalize. Finally, despite attempts to validate the overconfidence findings, I cannot rule out the possibility that the overconfidence results may reflect alternative circumstances. 


\section{CHAPTER 2 - INDIVIDUAL INVESTORS AND ANALYSTS' SIGNALS}

\subsection{INTRODUCTION}

Over the past few decades there has been a significant amount of research documenting the usefulness and market response of sell-side analyst guidance (e.g., Womack 1996; Mikhail, Walther, and Willis 1997, 2004; Michaely and Womack, 1999; Howe, Unlu, and Yan 2009; Barniv, Hope, Myring, and Thomas 2010; Drake, Rees, and Swanson 2011); yet despite the coverage of these studies, there has been limited research examining how different investor types use and respond to analysts' information. Specifically, individual investors are the primary group of investors that one would expect to benefit the most from analyst guidance (e.g., Bradshaw 2010) as individuals, on average, are less sophisticated and less informed investors (e.g., Barber and Odean 2000; De Franco, Lu, and Vasvari 2007; Kaniel, Liu, Saar, and Titman 2008; Taylor 2010; Koonce, Williamson, and Winchel 2010) who would likely profit from analysts' market timing, information-processing, and stock picking abilities.

To date there has been no large-scale research that examines whether and how individuals use sell-side analysts' guidance, and moreover, investigates variation among individuals in their use of such guidance. The most related studies to these questions are those that investigate whether small traders, classified based on trade sizes, differ from large traders in acknowledging

analysts incentives and potential misleading behaviors (e.g., He, Mian, and Sangkaraguruswamy 2005; De Franco et al. 2007; Malmendier and Shanthikumar 2007; Mikhail, Walther, and Willis 2007). These studies provide mixed evidence concerning how small traders respond to analysts' recommendations but conclude that small traders are naïve about analysts' incentives and the effects of such incentives on analysts' credibility. 
Using detailed data of individual investors from a discount-brokerage firm, this study examines how individuals react to and use sell-side analysts' recommendations and earnings guidance. Building on the findings that volume significantly increases around analyst guidance announcements (e.g., Womack 1996) and the argument suggested above that individuals are a group of investors that would most likely benefit from analysts' guidance, I expect that individuals will significantly react to the information contained in analysts' recommendation and earnings forecast revisions. However, given that individuals represent a diverse group of investors and that prior research suggests that at times individuals are contrarians (e.g., Kaniel, Saar, and Titman 2008; Bloomfield, Tayler, and Zhou 2009), it is unlikely that all individuals will respond in accordance with analysts' guidance. The extant literature argues that recommendations reflect analysts' beliefs about value relative to price (e.g., Francis and Soffer 1997; Bradshaw 2004) reflecting a decision with many inputs whereas, earnings forecasts are just one of those decision inputs (e.g., Schipper 1991). Thus, I predict that individuals, on average, will react more strongly to recommendation revisions than to earnings forecast revisions as recommendations represent more fundamental changes in analysts' opinions of value than earnings forecasts, and that some individuals may find it difficult to appreciate the link between earnings forecasts and valuation. However, there is tension in this prediction as analysts' earnings forecasts are better indicators of future returns than are recommendations (e.g., Bradshaw 2004; Barniv, Hope, Myring, and Thomas 2009) and thus, one would expect more information content from earnings forecast revisions and in turn, a larger response by investors to earnings forecasts than to recommendations.

Given that the discount-brokerage data used in this study contain information pertaining to the personal characteristics of individuals, I am able to provide the first empirical tests of the 
heterogeneity of individuals in their use of analysts' signals. Specifically, I whether examine personal attributes known to affect trading behavior (e.g., past performance, total equity holdings, trading frequency, age, etc.) affect whether individuals trade consistently with or contrarian to analysts' signals. Moreover, to complement the foregoing analyses, I investigate the return consequences of trading with or against analysts' recommendations and earnings forecasts. As prior research documents positive (negative) abnormal returns surrounding analysts' upgrades (downgrades) (e.g., Womack 1996; Ertimur, Sunder, and Sunder 2007; Howe et al. 2009) and given the notion that individuals, on average, will not be able to spot analysts' mispricing errors, I expect that those individuals who trade against analysts' guidance will on average earn lower returns than those individuals who trade consistently with analysts' guidance. Again this prediction is not obvious as several studies fail to find evidence that it is profitable to follow analysts' guidance (e.g., Barber, Lehavy, McNichols, and Trueman 2001; Drake et al. 2011).

Overall, the study presents evidence suggesting that individual investors use and trade on the information contained in analysts' recommendations and earnings forecasts. I find that, on average, individuals' abnormal trading activity increases by approximately 30 percent in response to analysts' recommendation revisions and by approximately 15 percent in response to analysts' earnings forecast revisions. Hence, individuals more strongly react to revisions in analysts' recommendations than in earnings forecasts, clearly reflecting the idea that individuals perceive recommendations to be more informative and/or find it easier to interpret the implications of simple instructions (i.e., buy, hold, sell) rather than earnings forecasts. Moreover, I find both abnormal buy and sell reactions to all analysts' announcements indicating that individuals do not operate as a collective homogenous group. Specifically, the analyses show that roughly 47 percent of individuals trade consistently with analyst guidance and 53 percent trade 
contrarian to analysts' guidance; thus, individuals are net contrarians in response to analysts recommendations but the contrarian dominance is marginal. The contrarian behavior is most pervasive in response to analyst downgrades. Specifically, individuals purchase after downgraded recommendations and earnings guidance, suggesting the contrarians' behavior could be partly driven by a strong attachment to prior optimistic beliefs concerning a particular firm.

Examining the individual characteristics of individuals, I find that several personal characteristics affect whether individuals trade contrarian to analysts' signals. In particular, the results show that contrarian behavior is most evident among individuals with better prior portfolio performance, individuals who trade infrequently, men, wealthier, and older individuals. In the returns analyses, the study provides evidence suggesting that, on average, individuals who trade consistently with analysts' guidance yield abnormal returns of approximately 0.8 percent $(p$ $<0.01)$ in the six months following the analyst guidance whereas individuals who trade contrarian to analysts yield abnormal returns of -1.3 percent $(p<0.01)$ : a spread of 2.1 percent $(p$ $<0.01$ ) over a six month period. The return distribution of these individuals suggests that individuals trade contrarian to analysts as there is a wider extreme right tail for those who trade against analysts versus those who trade consistently with analysts; hence, it appears that the trading against analysts could result in more extreme positive returns. The results further reveal that this return discrepancy is more pronounced for those individuals who trade excessivelyindividuals who are often regarded as overconfident by the prior literature (e.g., Odean 1998; Barber and Odean 2000, 2001; Statman, Thorley, and Vorkink 2006)—suggesting that the prior findings that excessive trading is hazardous to individuals' health (e.g., Barber and Odean 2000, 2001) can partially be attributed to trading against analysts' guidance. However, the results also indicate that older and wealthier individuals (proxies for investor sophistication) earn higher 
returns when trading against analysts' guidance than those of the average individual when trading against analysts' guidance, suggesting that these sophisticated investors are relatively more likely to intelligently disagree with analysts' recommendations and forecasts. Overall though, the returns analyses indicate that trading against analysts' signals is hazardous to individuals' financial health.

This study is the first to empirically examine how individuals' trade in response to analysts' signals, and to provide evidence suggesting that individuals' do not respond to analysts' signals as a homogenous group and that their use of analysts' guidance varies significantly with respect to their personal attributes. Moreover, it documents that approximately half of individuals trade contrarian to analysts' signals and earn significantly negative abnormal returns, and that approximately half of individuals trade consistently with analysts' signals, and earn significantly positive returns. Furthermore, the findings suggest that regulators such as the Investor Advisory Committee (IAC) of the Securities and Exchange Commission (SEC) would be best advised to warn and educate individuals concerning the financial risks associated with trading against analysts' guidance.

The following section reviews related literature and develops testable hypotheses. Section 2.3 describes sample formation, methods, and variable measurement. Section 2.4 presents the empirical results and Section 2.5 concludes.

\subsection{RELATED LITERATURE AND HYPOTHESES}

\subsubsection{Related Literature}

There is a significant amount of research documenting the usefulness and profitability of sell-side analyst guidance (see Bradshaw 2010). In particular, Womack (1996) shows early 
evidence that analysts' recommendations identify mispricing opportunities and that analysts' downgrades have a greater price impact than upgrades. Moreover, numerous of studies since (e.g., Mikhail et al. 1997, 2004, 2007; Michaely and Womack, 1999; Howe et al. 2009; Barniv et al. 2010) show that analysts' recommendations are profitable and contain relevant market information. However, due to data availability, there is limited research investigating how different investor types use and respond to such information. In particular, there has been no large-scale research that examines whether and how individuals, a group of investors that could perhaps benefit the most from analysts' expertise, market timing, and information processing, use sell-side analysts' guidance. The most related research investigates whether small traders, classified based on trade sizes, differ from large traders in responding to analysts' misleading behavior and potentially biased incentives.

Specifically, De Franco et al. (2007) show that misleading analyst guidance, identified in the Global Research Analysts Settlement, is less likely identified by small traders than larger traders. In a similar vein, Malmendier and Shanthikumar (2007) investigate whether small traders are naïve about analysts' affiliation with the underwriter, and find evidence suggesting that small traders follow all recommendations literally and do not appear to discount recommendations when they are potentially biased. Mikhail et al. (2007) also find evidence that small traders do not appear to recognize less credible recommendations, proxied by analyst downgrades versus upgrades; however, they find that small investors are net purchasers surrounding the recommendation announcement regardless of the information content of the analysts' recommendations. Hence, there is some evidence that small traders react to analysts' recommendations but the evidence concerning how they react is mixed. The mixed findings could in part be due to the fact that simple size cutoffs used in previous studies tend to be 
inaccurate as small trades used to proxy for individuals' investment activity reveal more institutional trading activity rather than individual trading activity (e.g., Campbell, Ramadori, and Schwartz 2009). Further, these studies are unable to consider or examine the heterogeneity of investors' responses to analysts' guidance and track their investment performance. Hence, as little is known about how individuals use and benefit from analysts' guidance, this study attempts to shed light on such questions.

\subsubsection{Hypotheses Development}

The first objective of the study is to document whether individuals appear to respond to and use analysts' guidance. Of all market participants (e.g., hedge funds, pension funds, insiders), individual investors, who on average are less sophisticated investors (e.g., Barber and Odean 2000; De Franco et al. 2007; Kaniel et al. 2008; Taylor 2010; Koonce et al. 2010), appear to be the primary group of investors that would benefit the most from analysts' informationprocessing and value estimating abilities (e.g., Bradshaw 2010). ${ }^{25}$ It appears that following analysts' guidance would help level the playing field, especially in a pre-Regulation Fair Disclosure (Reg FD) setting, as individuals may lack the time or ability to process complex financial information and are often outside of the inside circles. ${ }^{26}$ Combining the foregoing argument with the finding that individuals respond to earnings announcements (Hirshleifer, Myers, Myers, and Teoh 2008; Kaniel et al. 2008; Taylor 2010), indicating that individuals react to information announcements, and the finding that the overall market volume significantly increases around analysts' announcements (e.g., Womack 1996), I expect that individuals will

\footnotetext{
${ }^{25}$ However, following analysts' guidance requires some degree of financial expertise to interpret and process which all individuals may not possess.

${ }^{26}$ Reg FD, passed into law in August 2000, mandates that all material information of publicly traded companies must be disclosed to all investors at the same time. Prior to this regulation, institutional investors and analysts would often receive market moving information prior to other investors (e.g., individual investors).
} 
significantly react to the information contained in analysts' recommendations and earnings forecasts. Hence, my first hypothesis, in alternative form, is as follows:

\section{H1a: Individual investors react to the information contained in analysts' recommendation revisions and earnings forecast revisions.}

The above hypothesis is not obvious, and hence, it remains an empirical question as the alternative: that individuals do not react to analysts' guidance, is plausible as prior research argues that individual investors are naïve and unsophisticated; and thus, they could not pay attention to or process such information. For example, Battalio and Mendenhall (2005) and Ayers, Li, and Yeung (2011) show that small traders anticipate earnings as a seasonal randomwalk and fail to incorporate information from analysts' forecasts in their expectations, suggesting that small traders do not use the information contained in analysts' guidance.

The second component of $\mathrm{H1}$ pertains to whether individuals' react differently to analysts' recommendations than to earnings forecasts. The extant literature suggests that recommendations reflect analysts' beliefs about value relative to price based on many inputs (e.g., Francis and Soffer 1997; Bradshaw 2004) whereas, earnings forecasts are just one of those decision inputs (e.g., Schipper 1991). Malmendier and Shanthikumar (2009) argue that recommendations are directed towards individuals and earnings forecasts are directed towards institutions as individuals can follow a simple signal but have difficulty in assessing the stock price impact of a change in earnings. Thus, I predict that individuals, on average, will react more strongly to revisions in analysts' recommendations than to revisions in earnings forecasts as: (i) recommendations likely represent more fundamental changes in analysts' opinions of value than earnings forecasts; and (ii) individuals may find it difficult to appreciate the link between 
earnings forecasts and valuation. Hence, the second component of $\mathrm{H} 1$, in alternative form, is as follows:

H1b: Individual investors react more significantly to revisions in analysts' recommendations than to revisions in earnings forecasts.

There is tension in the foregoing prediction as analysts' earnings forecasts are better predictors of future returns than are recommendations (e.g., Bradshaw 2004; Barniv, Hope, Myring, and Thomas 2009) and thus, given this finding, one would expect a larger response by investors to earnings forecasts than to analysts' recommendations as there is greater information content in earnings forecasts.

Prior empirical research investigating individuals' use of financial reporting information generally considers individuals as a homogenous group of investors (e.g., Lee 1992; Hirshleifer et al. 2008) and does not explore possible cross-sectional variations among different types of individuals. However, several studies document that individuals' investment patterns vary with individual characteristics such as gender (e.g., Barber and Odean 2001), overconfidence (e.g., Barber and Odean 2000, 2001), tax preferences (e.g., Barber and Odean 2004), and investment location (e.g., Ivković and Weisbenner 2005). Moreover, recent evidence suggests that individuals display contrarian behavior (e.g., Kaniel et al. 2008; Bloomfield et al. 2009). Considering these findings and the idea that individuals represent a diverse group of investors, it is unlikely that all individuals will respond in accordance with analysts' guidance. Hence, I expect that a significant number of individuals will trade consistently with analysts' guidance and a significant number will trade contrary to analysts' guidance. Furthermore, individual characteristics such as sophistication, overconfidence, past performance, trading frequency, shown to influence investment strategies, will likely affect individuals' use of analysts' signals. 
However, as there is mixed evidence as to whether contrarian behavior represents more informed or uniformed investors (e.g., Kaniel et al. 2008; Bloomfield et al. 2009), I do not make directional predictions concerning which characteristics will likely contribute to contrarian behavior. Thus, the second and third hypotheses in alternative form are as follows:

\section{H2: Individual investors will be divided in their responses to analysts'signals.}

H3: Individual investors' personal attributes will relate to whether they trade consistently or contrarian to analysts' signals.

To supplement the foregoing analyses and to shed light on why some individuals might trade contrarian to analysts, I investigate the return consequences of trading with or against analysts' recommendations and earnings forecasts. Although I make no formal predictions, as a significant amount of research documents positive (negative) abnormal returns surrounding analysts' upgrades (e.g., Womack 1996; Ertimur et al. 2007; Howe et al. 2009) and given the notion that individuals, on average, will not spot analysts' mispricing errors, I expect that those individuals who trade against analysts' guidance will on average earn lower returns than those individuals who trade consistently with analysts' guidance.

\subsection{SAMPLE, METHODS, AND VARIABLE MEASUREMENT}

\subsubsection{Sample}

The brokerage dataset used in this study includes the trades and portfolio positions of individual investors at a major U.S. discount-brokerage firm for the period between January 1991 and December 1996. These brokerage data were obtained from Terrance Odean of the University of California at Berkeley. The brokerage data contain a sample of 78,000 households, representing 158,034 separate individual accounts, selected from a total client base of 1.25 
million households. ${ }^{27}$ The empirical tests in this study are conducted in two separate analyses: an event study, in which all individuals' trading activity is aggregated together, and a series of regression analyses, where the regressions are performed at the individual account level. The event-study sample reflects the intersection of all analysts' recommendations and earnings forecasts issued between October 1993 and December 1996 in I/B/E/S with individuals' aggregated trading information from the brokerage data. The sample period begins in October 1993 as this is when analysts' recommendations were first recorded in $\mathrm{I} / \mathrm{B} / \mathrm{E} / \mathrm{S}$ and ends in December 1996 as the brokerage data spans from 1991 to 1996 . The event study sample consists of 67,811 analysts' recommendations for 5,130 firms and 242,224 analysts' earnings forecasts for 5,407 firms.

The regression analyses sample, which is constructed at the individual-firm-analystannouncement level (explained in the Methods and Variable Measurement section below), reflects the intersection of the individual account level data with firm, market-level, and analyst guidance data from COMPUSTAT, CRSP, Ken French's website, and I/B/E/S. After starting with the event study sample and restricting the sample to: (i) upgraded (UPGRADE) and downgraded (DOWNGRADE) analyst earnings forecasts and recommendations; and (ii) those observations with information to calculate control variables using COMPUSTAT and CRSP data, I obtain a sample of 173,124 individual-firm-analyst-announcement earnings forecast observations covering 2,737 unique firms, and a sample of 33,909 individual-firm-analyst-announcement observations covering 1,716 unique firms.

\footnotetext{
${ }^{27}$ For more information concerning the brokerage data, see Barber and Odean (2000), Kumar and Lee (2006), Hirshleifer et al. (2008), and Taylor (2010). A possible concern with using portfolio records from one discount broker is whether these records are representative of the portfolios of the whole individual investor population. Previous studies provide some support for the validity of these brokerage data as they find that trades in the dataset are correlated with information reported on individuals' tax returns and with trades of other brokerage firms (e.g., Ivković, Poterba, and Weisbenner 2005; Barber and Odean 2008).
} 


\subsubsection{Methods and Variable Measurement}

The first analysis, the event study, examines individuals' abnormal reaction to analysts' recommendation and earnings forecast revisions, and attempts to investigate H1. For each announcement $t$, an earnings forecast or recommendation revision made by analyst $q$, I examine individuals' aggregated trading volume in the ten days prior and following the announcement. Individuals' aggregated trading volume during the event window is calculated each day and is scaled by the average trading volume in the 15 trading days prior to the event window to capture abnormal trading activity. Inferences are the same whether the pre-event estimation volume is calculated over windows up to 365 days prior to the event window. To assess whether individuals respond to analysts' signals as a homogenous group, the abnormal trading volume is calculated separately for both the buy and sell transactions.

Following the event study, I employ a series of regression analyses to test $\mathrm{H} 2$ and $\mathrm{H} 3$ by examining the percentage of individuals that trade consistently with analysts' guidance and whether specific individual and firm attributes affect individuals' use of analysts' signals. Specifically, these regressions focus on factors that contribute to individuals' trading consistently (IN_LINE) with analysts' earnings forecasts and recommendations. IN_LINE equals "1" if individual $i$ trades in line with analyst $q$ 's guidance, and " 0 " otherwise. For example, IN_LINE equals " 1 " when analyst $q$ issues a strong buy recommendation for firm $j$ while the consensus recommendation was a buy and individual $i$ purchases the stock in days -1 to +1 surrounding the recommendation announcement. Likewise for earnings forecasts, IN_LINE equals “1" when analyst $q$ issues an earnings forecast of $\$ 2.00$ per share while the consensus earnings forecast for firm $j$ was $\$ 1.80$ per share and individual $i$ purchases the stock in days -1 to +1 surrounding the earnings forecast announcement. The specific regression model employed is as follows: 


$$
\begin{aligned}
I N \_L I N E_{i j q t}=\quad & \beta_{0}+\beta_{1} I N D \_P A S T \_R E T_{i t}+\beta_{2} I N D \_E Q U I T Y_{i j t}+\beta_{3} T R A D E \_F R E Q_{i t} \\
& +\beta_{4} G E N D E R_{i}+\beta_{5} A G E_{i}+\beta_{6} A B S \_C H G_{j q t}+\beta_{7} L O G M A R K E T_{j t} \\
& +\beta_{8} P / E_{j t}+\beta_{9} R E T \_V O L_{j t}+\beta_{10} R A W_{-} R E T_{j t}+\beta_{11} B E T A_{j t} \\
& +\beta_{12} R O E_{j t}+\beta_{13} A N A L Y S T \_P E R F_{q t}+\beta_{14} B R O K E R \_S I Z E_{q t} \\
& +\beta_{15} R E C O M M E N D A T I O N_{j q t}+I N D U S T R Y \_F E+Y E A R \_F E \\
& +\varepsilon_{i j q t}
\end{aligned}
$$

For full variable definitions see Appendix B. IND_PAST_RET, IND_EQUITY, TRADE_FREQ, and GENDER are included in the analyses to capture individual investors' attributes that could affect whether individuals trade consistently with analysts' guidance. IND_PAST_RET reflects individuals' investment performance in the year prior to the analyst announcement, and IND_EQUITY captures individuals total equity holdings. Higher values of both variables likely proxy for greater investor sophistication and could influence whether individuals ex ante could spot analysts' mispricing errors. TRADE_FREQ and GENDER are included in the model to attempt to measure investor overconfidence, following Barber and Odean (2000, 2001), as overconfident individuals could be more likely to trade against analysts' guidance if they place too much weight on private versus public information (e.g., Daniel et al. 1998; Odean 1998).

The change in analysts' expectations of firm performance can be measured by the magnitude of the recommendation revision $\left(A B S \_C H G\right)$ (Asquith, Mikhail, and Au 2005). The greater the magnitude of the change could affect whether individuals perceive the signal as credible. LOGMARKET, P/E, RET_VOL, RAW_RET, BETA, ROE are firm attributes that may impact individuals beliefs about firm price and their reliance on analysts' guidance especially if they are less informed in certain types of firms (e.g., high $\mathrm{P} / \mathrm{E}$ or volatile firms). As analysts' performances are relatively persistent (Mikhail et al. 2004), I expect that individuals may tend to follow the guidance from analysts' with stronger track records (ANALYST_PERF). Large 
brokerage firms have extensive marketing channels (Stickel 1995) and hence, their recommendations could receive more attention from individuals. Equation (1) is run for all analysts' signals (earnings forecasts and recommendations) and for each type of guidance separately, to indentify whether contrarian behavior differs with respect to the type of signal.

I also examine whether individuals' abnormal returns after trading on analysts' signals vary with respect to whether they trade consistently or contrary to the guidance. The following regression is used to investigate these questions:

$$
\begin{aligned}
\text { FUT_RETURNS } S_{i j q t}= & \beta_{0}+\beta_{1} I I_{\_} L I N E_{i j q t}+\beta_{2} A B S \_C H G_{j q t}+\beta_{3} U P G R A D E_{j q t} \\
& +\beta_{4} I N D \_P A S T \_R E T_{i t}+\beta_{5} F U T \_B E T A_{j, t}+\beta_{6} S M B_{j t} \\
& +\beta_{7} H M L_{j t}+\beta_{8} C A R H A R T \_M O M E N T U M_{j t} \\
& +\beta_{9} R E C O M M E N D A T I O N_{j q t}+I N D U S T R Y \_F E+Y E A R \_F E \\
& +\varepsilon_{i j q t}
\end{aligned}
$$

For full variable definitions see Appendix B. The main coefficient of interest in this analysis is the coefficient on IN_LINE: $\beta_{1}$. As mentioned in the previous section, I expect $\beta_{1}$ to be positive given the prior research showing the profitability of analysts' recommendations. Again following Asquith et al. (2005), I use the magnitude of the guidance revision (ABS_CHG) to capture analysts' change in expectations of firm performance. I expect larger changes in analysts' expectations to relate to greater price responses and predict a positive coefficient on $A B S \_C H G$. Individuals' past performance (IND_PAST_RET) controls for the notion that better performing individuals may be able to consistently make effective investment decisions. Drawing from prior research, FUT_BETA, SMB, HML, and CARHART_MOMENTUM are included in the model to control for risk factors that influence returns. 


\subsection{RESULTS}

\subsubsection{Event Study: Individuals' Abnormal Reactions}

The following section examines individuals' aggregate trading responses to analysts' recommendations and earnings forecasts. Figure 1, Panel A plots individuals' aggregated reaction to analysts' recommendation revisions. The y-axis represents individuals' abnormal trading activity as a percentage of their average trading volume in the fifteen days prior to the event window and the $\mathrm{x}$-axis represents the number of trading days from the recommendation announcement day as per $\mathrm{I} / \mathrm{B} / \mathrm{E} / \mathrm{S}$. The solid line charts abnormal buy volume and the broken line charts abnormal sell volume. As evident from the figure, individual investors significantly $(p<$ 0.01) respond to analysts' recommendation announcements. Specifically, there is a significant response for both abnormal buying activity and abnormal selling activity on event day 0 of approximately 35 percent for abnormal buys and 25 percent for abnormal sells. Even though the largest response occurs on event day 0 , the majority of the abnormal reaction spreads between event days -1 to +1 . The abnormal response runs up before event day 0 as the date recorded in I/B/E/S does not necessarily reflect the public announcement date but rather the date that I/B/E/S received the recommendation or earnings forecast (e.g., Stickel 1992). In addition, analysts' tend to cluster their guidance together (e.g., Stickel 1989) so that is likely the slightly positive abnormal trading during the week prior and following the announcement reflects the effects of analyst clustering their announcements. When dropping all overlapping recommendations from the analyses, all main inferences hold; however, the abnormal reaction is more pronounced for event day 0 relative to the other event days than in the current figure.

Moving to Panel B, which documents individuals' aggregate response to analysts' earnings forecast revisions, I find a similar response to the one documented in Panel A for 
analysts' recommendations. Specifically, I find a significant abnormal response $(p<0.01)$ of approximately 15 percent for both abnormal buys and sells on event day 0 for analysts' earnings forecasts. The earnings forecast response has more of a run up than the recommendation response which is probably caused by the fact that analysts tend to issue the majority of their earnings forecasts in the period following the earnings announcement. I find similar inferences when dropping all earnings forecasts with earnings announcements in the event window from the analyses; although, the run-up as shown in Panel B is less pronounced. Overall, Panels A and B provide support for H1a that individuals' react to the information contained in analysts' recommendations and earnings forecasts.

Figure 1, Panel C provides a direct comparison between individuals' total abnormal response to revisions in analysts' recommendations and in analysts' earnings forecasts. The total abnormal trading volume is approximately 30 percent for analysts' recommendation announcements and 15 percent for earnings forecast announcements; thus, individuals' reactions to analysts' recommendation revisions are double those for analysts' earnings forecast revisions $(p<0.01)$. Thus, Panel $\mathrm{C}$ provides support for $\mathrm{H} 1 \mathrm{~b}$ that individuals react more significantly to analysts' recommendations than to their earnings forecasts. This finding is possibly attributable to the facts that recommendations represent more fundamental changes in analysts' opinions of value than earnings forecasts and that individuals may not fully appreciate the link between earnings forecasts and valuation, and hence, they find a simple signal easier to trade on.

In Figures 2 and 3, I attempt to shed light on whether individuals react as a homogenous group by investigating individuals' response when they receive directional signals from analysts' revisions. Figure 2 Panel A presents individuals' reactions to 20,486 analysts' upgraded recommendations. As in Figure 1, the solid line charts abnormal buy volume and the broken line 
(with small triangles) charts abnormal sell volume. To provide insights as to whether price movements are driving the abnormal trading (e.g., Kaniel et al. 2008), I also include the average price movement, which is normalized to 100 on day -10 and marked by a dotted line, throughout the trading window. ${ }^{28}$ Figure 2, Panel A shows that there is both significant $(p<0.01)$ abnormal buy and sell activity on day 0 of approximately 30 percent, suggesting that there is a group of individuals who follow analysts recommendations literally and a group who take contrarian positions to analysts' recommendations. The contrarian response slightly outweighs the consistent response but the economic significance of the difference appears marginal. The normalized price movement suggests the abnormal trading is a result of the recommendation announcements and not of the price changes as the majority of the abnormal volume appears to lead the price movements. Figure 2, Panel B, which charts individuals reaction to 89,133 analysts' upgraded earnings forecasts provides similar inferences to Figure 2, Panel A but for analysts' earnings forecasts.

Figure 3, Panels A and B, show individuals' abnormal reactions to 27,403 downgraded recommendations and 149,798 downgraded earnings forecasts, respectively. In Panel A, there is a very strong abnormal buy reaction of 40 percent, which is almost double that of the abnormal sell reaction of 20 percent. Both abnormal buy and sell reactions are significant at the one percent level for event days -1 to +1 . Thus, there is a significant group of investors that trade consistently with analysts' recommendation downgrades but even a greater group of investors that trade contrarian to analysts' recommendation downgrades. The inferences in Panel B for downgraded earnings forecasts are similar to those in Panel A but the contrarian effect relative to the consistent effect is less pronounced: 17 percent versus 14 percent, respectively. Hence, the

\footnotetext{
${ }^{28}$ For example, it is possible that the overall market responds to analysts' guidance and hence, the price changes. Then at that point, individuals respond to the price change and not to the actual analyst guidance.
} 
results imply that during analysts' upgraded guidance, approximately half of the abnormal reaction is consistent with analysts' guidance and half of the abnormal reaction is contrarian to analysts' guidance. However, during downgraded guidance there are at least 20 percent more contrarian abnormal reactions than consistent abnormal reactions. Taken together, the findings in Figures 2 and 3 provide some support for the idea that individuals are not homogenous in their responses to analysts' signals. The difference in responses among individuals obviously reflects diverse views about the underlying value of the firm. In the following multivariate analysis section, I further examine whether individuals diverge in their trading responses to analysts' signals and whether these differences in views can be attributed to specific individual characteristics while controlling for firm characteristics.

But first, I will quickly highlight the results in Figure 4, Panels A and B that report individuals' abnormal trading volume relative to the overall market's abnormal trading volume. As seen in both panels, individuals' responses appear fairly consistent with the market's responses to analysts' guidance. Such findings provide indirect evidence that given similar total market responses, the other side of the market must be trading more in line with analysts' downgraded opinions than individuals, as individuals are net contrarians during these times. However, I limit further comparisons to the broader market participants as these comparisons are difficult to make when data relating to both groups' respective trading activities are unavailable. An important takeaway from Figures 1 to 4 is that individuals react quickly to the information contained in analysts' guidance, when the internet was not yet pervasive, supporting the notion that individuals are fairly connected to information events and are not naïve on average if they are identifying and trading timely on such information. 


\subsubsection{Multivariate Analyses}

Table 23 provides descriptive statistics for the multivariate analyses samples. As mentioned in Section 2.3, the recommendation sample contains 33,909 observations and the earnings forecasts sample contains 173,124 observations. The descriptive statistics show that 46 percent of individuals trade consistently (IN_LINE) with analysts' recommendations and 48 percent of individuals trade consistently with analysts' earnings forecasts, confirming the findings from the previous analyses and further supporting $\mathrm{H} 2$ : that individuals do not act as a homogenous group of investors in response to analysts' guidance. Overall, the descriptive statistics for the control variables are fairly similar across the two samples.

Table 24 provides regression evidence using Equation (1) relating to the determinants of whether individuals trade consistently with analysts' recommendations and earnings announcements. Columns (I) and (IV) present the results for all analysts' guidance; Columns (II) and (V) present the results for analysts' upgrades; and Columns (III) and (VI) present the results for analysts' downgrades. Moreover, Columns (I) to (III), present the results of Equation (1) without $G E N D E R$ and $A G E$, as they reduce the sample sizes as this information is not available for all investors, and Columns (IV) to (VI), present the results with GENDER and AGE.

In Columns (I) and (IV), I find that, on average, for all analyst guidance that individuals are less likely to trade consistently with analysts if their past portfolio returns are higher as the coefficients on IND_PAST_RET are -0.598 and -0.620 , and significant $(p<0.01$ and $p<0.05)$, respectively. I find similar inferences for downgrades in Columns (III) and (VI) and mixed results for upgrades in Columns (II) and (V). These individuals possibly trade against analysts as they believe that they could spot analysts mispricing errors given their past successes. The results show that wealthier individuals are asymmetric in how they respond to analysts' guidance: they 
are less likely to follow upgrades and are more likely to follow downgrades as the coefficients on IND_EQUITY in Columns (II) and (V) are -0.015 and significant $(p<0.01)$, and the coefficients on IND_EQUITY in Columns (II) and (V) are 0.012 and significant $(p<0.01)$. These findings support the notion that wealthier (more sophisticated individuals) recognize that downgrades are generally more credible than upgrades (e.g., Womack 1996; Asquith et al. 2005; Mikhail et al. 2007).

The analyses also show that individuals who trade frequently are more likely to follow analysts' guidance and in particular downgrades as the coefficients on TRADE_FREQ in Columns (III) and (IV) are positive and significant $(p<0.01)$. Furthermore, women are more likely to follow analysts' downgrades than men, possibly due to the fact that they are, on average, less overconfident (e.g., Barber and Odean 2001) as the coefficient on GENDER in Column (VI) is 0.068 and significant $(p<0.05)$. Individuals' age also appears to affect whether they listen to analysts. Specifically, older individuals, on average, follow analysts less than younger individuals as the coefficient on $A G E$ is -0.001 and significant $(p<0.05)$ in Column (IV). Taken together these findings provide strong support for $\mathrm{H} 3$ that individual investors' personal attributes relate to whether they trade consistently or contrarian to analysts' signals. Moreover, they confirm the idea that individuals are a diverse group of individuals with many different beliefs.

The coefficients on $A B S \_C H G$ show that individuals appear skeptical in following analysts' guidance the further it is from the consensus as the coefficients on $A B S \_C H G$ in the majority of specifications are negative and significant $(p<0.01)$. This finding, like previous ones, also supports the idea that individuals may not be as naïve as some previous studies suggest. Summarizing the results of the remaining control variables in Table 24, I find that 
individuals are more likely to follow analysts' guidance in smaller, lower $\mathrm{P} / \mathrm{E}$, and less profitable firms. Also interesting to note is that the coefficients on RECOMMENDATION are mostly all negative and significant $(p<0.05)$ suggesting that individuals are more likely to trade contrarian to analysts for analysts' recommendations than for earnings forecasts. Tables 25 and 26 provide similar analyses as presented in Table 24 but Table 25 presents the results for analysts' recommendations and Table 26 presents the results for analysts' earnings forecasts. Generally, all inferences from Tables 25 and 26 are very similar to those from Table 24; however, I do not find any evidence that gender and age affect individuals' use of analysts' recommendations (see Table 25). This finding is likely attributable to the smaller sample sizes and hence, a loss of power.

The previous analyses investigate which individuals are more likely to follow analysts' signals whereas the following analyses examine the financial consequences of following, or not following, analysts' signals. Table 27 presents univariate analyses of individuals' six month returns following trading on analysts' guidance. Panel A presents the findings for both recommendations and earnings forecasts; Panel B presents the findings for recommendations; and Panel $\mathrm{C}$ presents the findings for earnings forecasts.

The descriptive statistics illustrate that it is hazardous for individuals to, on average, trade against analysts' signals. Specifically, in Panel A, the mean abnormal return for those who trade consistently with analysts' guidance $\left(I N \_L I N E=1\right)$ is $0.008(p<0.01)$ whereas the mean abnormal return for those who trade contrarian to analysts' guidance (IN_LINE $=0)$ is -0.013 ( $p<$ $0.01)$ : a spread of approximately 2.0 percent $(p<0.01)$ over six months. What is interesting is that the mean return is -0.003 which is similar to the findings in previous research that individuals, on average, earn lower returns than the market. Yet, following analysts appears to significantly help individuals achieve better financial returns and out-perform the market. The 
inferences and findings in Panels $\mathrm{B}$ and $\mathrm{C}$ are consistent with those in Panel A. Examining the distribution of abnormal returns (FUT_RETURNS), it appears that following analysts is consistently a better option at all points of the distribution except in the extremely positive cases. For instance, the maximum abnormal return for going against analysts $\left(I N \_L I N E=0\right)$ is 2.423 whereas the maximum abnormal return for following analysts $\left(I N \_L I N E=1\right)$ is 1.55 : a spread of 0.468. Thus, the extreme positive payouts could be one plausible explanation as to why individuals trade against analysts' guidance.

Table 28, which presents the multivariate return regressions using Equation (2), confirms the univariate findings in Table 27 that trading against analysts' results in lower abnormal returns. Column (I) presents the findings for the combined recommendation and earnings forecast sample; Column (II) presents the findings for the recommendation sample; and Column (III) presents the findings for the earnings forecast sample. Specifically, the coefficients on IN_LINE in all samples are negative and significant $(p<0.01)$, and indicate an approximate 2.0 percent spread between following and not following analysts' guidance. Another notable finding is the result that individuals' returns are lower for analysts' upgrades than for downgrades, which is consistent with the prior research that documents greater abnormal returns to downgrades (e.g., Womack 1996; Jegadeesh, Kim, Krische, and Lee 2004). Moreover, I find that the coefficients on $I N D \_P A S T \_R E T$ are insignificantly different than zero in all samples, suggesting that on average individuals cannot continuously beat the market.

To complement the foregoing analyses, I examine how individuals' returns vary with personal attributes when trading in line with analysts' guidance. To perform this analysis, I modify Equation (2) to add an interaction term between IN_LINE and the following personal characteristics: IND_PAST_RET, IND_EQUITY, TRADE_FREQ, GENDER, and AGE. Table 29 
presents the findings of these separate regressions. Column (I) reports that individuals' returns from following analysts' guidance are not affected by the individual's prior portfolio performance as the coefficient on INT*IN_LINE in Column (I) is -0.047 and insignificant. Column (II) shows that the coefficient on INT, when INT=IND_EQUITY, is 0.001 and significant $(p<0.01)$, suggesting that wealthier individuals (a proxy for sophistication) earn higher returns when trading during analysts' announcements. Moreover, the coefficient on INT*LINE is -0.002 and significant $(p<0.01)$, revealing that wealthy individuals earn higher returns when trading against analysts' guidance than the average individual. Column (III), in which $I N T=T R A D E \_F R E Q$, provides weak evidence suggesting that individuals who trade excessively (often regarded as overconfidence) earn lower abnormal returns as the coefficient on is -0.001 and weakly significant $(p<0.10)$. Examining the coefficient on INT*LINE, which is 0.004 and significant $(p<0.01)$, indicates that the benefits to following analysts' are more pronounced for overconfident individuals and that the prior findings that excessive trading is hazardous to individuals health (e.g., Barber and Odean 2000, 2001) can partially be attributed to trading against analysts' guidance.

In Column (IV), I find no evidence suggesting that gender has a bearing on individuals' returns when trading during periods of analyst guidance; however, in Column (V) I do find that older individuals earn greater returns trading during analyst announcements as the coefficient on $I N T$ is positive and significant $(p<0.01)$. Furthermore, I find that the coefficient on $I N T^{*} L I N E$ is -0.000 and significant $(p<0.01)$ suggesting that older individuals earn higher returns when trading contrary to analysts than do average individuals. In summary, the returns analyses indicate that older and wealthier individuals earn higher returns and overconfident individuals earn lower returns when trading against analysts' guidance than those of the average individual; 
suggesting that astute investors are relatively more able to intelligently disagree with analysts' guidance.

\subsection{CONCLUSION}

Using detailed data of individual investors, this study examines how individuals' react to revisions in analysts' recommendations and earnings forecasts. The study shows that individuals' abnormal trading activity significantly increases in response to revisions in both analysts' recommendations and earnings forecasts. Moreover, the analyses indicate that roughly 47 percent of individuals trade consistently with analyst guidance and 53 percent trade contrarian to analysts' guidance, which opposes the belief that individuals are a homogenous group of investors. I find that contrarian behavior is most common among individuals with better prior performance, individuals who trade infrequently, men, and older individuals. Lastly, the study provides evidence suggesting that trading contrarian to analysts is in general hazardous to individuals' financial health. Taken together, the results indicate that individuals respond to analyst guidance and that individuals' use of analyst guidance varies significantly with respect to their personal attributes.

Similar to other studies that use proprietary data from a certain time period and a single source, my findings must be interpreted with due regard to their limitations. First, the individual investor trading and shareholdings data used in this study are from the 1990s. Thus, given the changes in the disclosure environment (e.g., Reg FD) and changes in how analysts' reports are now distributed over the web, the extent to which the findings would differ from those today is unknown. Second, the reader should consider the sample selection criteria imposed on this study by using data from a single brokerage firm when determining how these results might generalize. 


\section{REFERENCES}

Ali, A., S. Klasa, and O. Li. 2008. Institutional stakeholdings and better-informed traders at earnings announcements. Journal of Accounting \& Economics 46 (1): 47-61.

Asquith, P., M. Mkihail, and A. Au. 2005 Information content of equity analyst reports. Journal of Financial Economics 75 (2): 245-282.

Ayers, B., O. Li, and P.E. Yeung. 2011. Investor trading and the post-earnings-announcement drift. The Accounting Review 86 (2): 385-416.

Barber, B., and T. Odean. 2000. Trading is hazardous to your wealth: The common stock investment performance of individual investors. Journal of Finance 55 (2): 773-806.

- and 2001. Boys will be boys: Gender, overconfidence, and common stock investment. Quarterly Journal of Economics 116 (1): 261-292.

— individual and institutional investors. Review of Financial Studies 21 (2): 785-818.

- _, and Zhu. 2009. Do retail trades move markets? Review of Financial Studies 22 (1): 151186.

, R. Lehavy, M. McNichols, and B. Trueman. 2001. Can investors profit from the prophets? Security analyst recommendations and stock returns. Journal of Finance 56 (2): 531-563.

Barniv, R., O.-K. Hope, M. Myring, and W. Thomas. 2009. Do analysts' practice what they preach and should investors listen? Effects of recent regulations. The Accounting Review 84 (4): 1015-1039.

$\longrightarrow,-$, , and 2010. International evidence on analyst stock recommendations, valuations, and returns. Contemporary Accounting Research 27 (4): 1131-1167.

Barron, O., O. Kim, S. Lim, and D. Stevens. 1998. Using analysts' forecasts to measure properties of analysts' information environment. The Accounting Review 73 (4): 421-433.

Bartov, E., S. Radhakrishnan, and I. Krinsky. 2000. Investor sophistication and patterns in stock returns after earnings announcements. The Accounting Review 75 (1): 43-63.

Battalio, R., and R. Mendenhall. 2005. Earnings expectations, investor trade size, and anomalous returns around earnings announcements. Journal of Financial Economics 77 (2): 289-319.

Beaver, W. 1968. The information content of annual earnings announcements. Journal of Accounting Research 6 (Selected Studies): 67-92.

Berger, P., and R. Hann. 2007. Segment profitability and the proprietary and agency costs of disclosure. The Accounting Review 82 (4): 869-906.

Bertsimas, D., and A. Lo. 1998. Optimal control of execution costs. Journal of Financial Markets 1 (1): $1-50$.

Bhattacharya, N. 2001. Investors' trade size and trading responses around earnings announcements: An empirical investigation. The Accounting Review 76 (2): 221-244.

—, E. Black, T. Christensen, and R. Mergenthaler. 2007. Who trades on pro forma earnings information? The Accounting Review 82 (3): 581-619.

Bhushan, R. 1994. An informational efficiency perspective on the post-earnings announcement drift. Journal of Accounting \& Economics 18 (1): 45-65.

Bloomfield, R. 2002. The "incomplete revelation hypothesis" and financial reporting. Accounting Horizons 16 (3): 233-243.

—, R. Libby, and M. Nelson. 1999. Confidence and the welfare of less-informed investors. Accounting, Organizations and Society 24 (8): 623-647.

—, W. Tayler, and F. Zhou. 2009. Momentum, reversal, and uninformed traders in laboratory markets. Journal of Finance 64 (6): 2535-2558.

- 2010. Traditional versus behavioral finance. Working Paper, Cornell University.

Botosan, C., and M. Plumlee. 2002. A re-examination of disclosure level and the expected cost of equity capital. Journal of Accounting Research 40 (1): 21-40. 
Bova, F., Y. Dou, and O.-K. Hope. 2011. Employee ownership and firm disclosure. Working Paper, University of Toronto.

Bradshaw, M. 2004. How do analysts use their earnings forecasts in generating stock recommendations? The Accounting Review 79 (1): 25-50.

- 2010. Analysts' Forecasts: What do we know after decades of work? Working paper, Boston College.

Brüggemann, U., H. Daske, C. Homburg, and P. Pope. 2009. How do individual investors react to global IFRS adoption? Working Paper, Lancaster University.

Bushee, B., and C. Noe. 2000. Corporate disclosure practices, institutional investors, and stock return volatility. Journal of Accounting Research (Supplement): 171-202.

, D. Matsumoto, and G. Miller. 2003. Open versus closed conference calls: The determinants and effects of broadening access to disclosure. Journal of Accounting \& Economics 34 (1-3): 149-180.

$\longrightarrow$ - — of Reg FD and conference calls. The Accounting Review 79 (3): 617-643.

— , and T. Goodman. 2007. Which institutional investors trade based on private information about earnings and returns? Journal of Accounting Research 45 (2): 289-321.

Campbell, J., T. Ramadorai, and A. Schwartz. 2009. Caught on tape: Institutional trading, stock returns, and earnings announcements. Journal of Financial Economics 92 (1): 66-91.

Carhart, M. 1997. On persistence in mutual fund performance. The Journal of Finance 52 (1): 57-82.

Clogg, C., E. Petkova, and A. Haritou. 1995. Statistical methods for comparing regression coefficients between models. American Journal of Sociology 100 (5): 1261-1293.

Cohen, J., L. Holder-Webb, D. Wood, and L. Nath. 2010. Retail investors' perceptions of the decisionusefulness of economic performance, governance and corporate social responsibility disclosures. Behavioral Research in Accounting (forthcoming).

Covrig, V., M. DeFond, and M. Hung. 2007. Home bias, foreign mutual fund holdings, and the voluntary adoption of international accounting standards. Journal of Accounting Research 45 (1): 41-70.

D’Souza, J., K. Ramesh, and M. Shen. 2010. The interdependence between institutional ownership and information dissemination by data aggregators. The Accounting Review 85 (1):159-193.

Daniel, K., D. Hirshleifer, and A. Subrahmanyam. 1998. Investor psychology and security market underand over-reactions. Journal of Finance 53 (6): 1839-1885.

De Franco, G., H. Lu, and F. Vasvari. 2007. Wealth transfer effects of analysts' misleading behavior. Journal of Accounting Research 45 (1): 71-110.

Deaves, R., C. Dine, and W. Horton. 2006. How are investment decisions made? Working Paper, Task Force to Modernize Securities Legislation in Canada.

Diamond, D., and R. Verrecchia. 1991. Disclosure, liquidity, and the cost of capital. Journal of Finance 46 (4): 1325-1359.

Drake, M., L. Rees, and E. Swanson. 2011. Should investors follow the prophets or the bears? Evidence on the use of public information by analysts and short sellers. The Accounting Review 86 (1): 101130.

Easley, D., and M. O'Hara. 2004. Information and the cost of capital. Journal of Finance 59 (4): 15531583.

Easterwood, J., and S. Nutt. 1999. Inefficiency in analysts' earnings forecasts: Systematic misreaction or systematic optimism? Journal of Finance 54 (5): 1777-1797.

Einhorn, H., and R. Hogarth. 1978. Confidence in judgement: Persistence of the illusion of validity. Psychological Review 85 (5): 395-416.

Elliott, W.B., F. Hodge, and K. Jackson. 2008. The association between nonprofessional investors' information choices and their portfolio returns: The importance of investing experience. Contemporary Accounting Research 25 (2): 473-498. 
Ertimur, Y., J. Sunder, and S.V. Sunder. 2007. Measure for measure: The relation between forecast accuracy and recommendation profitability of analysts. Journal of Accounting Research 45 (3): 567-606.

Fama, E., and K. French. 1993. Common risk-factors in the returns on stocks and bonds. Journal of Financial Economics 33 (1): 3-56.

Financial Accounting Standards Board (FASB). 1978. Statement of Financial Accounting Concepts No. 1, Objectives of financial reporting by business enterprises. Norwalk, CT: FASB.

Finucane, T. 2000. A direct test of methods for inferring trade direction from intra-day data. Journal of Financial and Quantitative Analysis 35 (4): 553-576.

Francis, J., I. Khurana, and R. Pereira. 2005. Disclosure incentives and effects on cost of capital around the world. The Accounting Review 80 (4): 1125-1162.

Francis, J., and L. Soffer. 1997. The relative informativeness of analysts' stock recommendations and earnings forecast revisions. Journal of Accounting Research 35 (2): 193-211.

Frankel, R, and X. Li. 2004. Characteristics of a firm's information environment and the information asymmetry between insiders and outsiders. Journal of Accounting and Economics 37 (2): 229259.

Garfinkel, J. 2009. Measuring investors' opinion divergence. Journal of Accounting Research 47 (5): 1317-1348.

Gigerenzer, G., U. Hoffrage, and H. Kleinbölting. 1991. Probabilistic mental models: A Brunswikian theory of confidence. Psychological Review 98 (4): 506-528.

Goel, A., and A. Thakor. 2008. Overconfidence, CEO selection, and corporate governance. Journal of Finance 63 (6): 2737-2784.

Grinblatt, M., and M. Keloharju. 2009. Sensation seeking, overconfidence, and trading activity. Journal of Finance 64 (2): 549-578.

Hales. J. 2007. Directional preference, information processing, and investors' forecasts of earnings. Journal of Accounting Research 45 (3): 607-628.

He, W., G. Mian, and S. Sangkaraguruswamy. 2005. Who follows the prophets? Analysts' stock recommendations and the trading response of large and small traders. Working paper, National University of Singapore.

Healy, P., A. Hutton, and K. Palepu. 1999. Stock performance and intermediation changes surrounding sustained increases in disclosure. Contemporary Accounting Research 16 (3): 485-520.

Hirshleifer, D., and S. Teoh. 2003. Limited attention, information disclosure, and financial reporting. Journal of Accounting and Economics 36 (1-3): 337-386.

- J. Myers, L. Myers, and S. Teoh. 2008. Do individual investors cause post-earnings announcement drift? Direct evidence from personal trades. The Accounting Review 83 (6): 15211550 .

Hope, O.-K. 2003. Disclosure practices, enforcement of accounting standards, and analysts' forecast accuracy: An international study. Journal of Accounting Research 41 (2): 235-272.

, and W. Thomas. 2008. Managerial empire building and firm disclosure. Journal of Accounting Research 46 (3): 591-626.

Howe, J., E. Unlu, and X. Yan. 2009. The predictive content of aggregate analyst recommendations. Journal of Accounting Research 47 (3): 799-821.

Indjejikian, R. 1991. The impact of costly information interpretation on firm disclosure decisions. Journal of Accounting Research 29 (2): 277-301.

International Accounting Standards Board (IASB). 2010. IASC Foundation and IASB Emphasise Greater Investor Participation in the Development of IFRSs. Press release, April 29, 2010.

International Accounting Standards Committee (IASC). 1989. Framework for the Preparation and Presentation of Financial Statements. London: IASC.

Ivković, Z., J. Poterba, and S. Weisbenner. 2005. Tax-motivated trading by individual investors. The American Economic Review 95 (5): 1605-1630. 
Jegadeesh, N., J. Kim, S. Krische, and C. Lee 2004. Analyzing the analysts. When do recommendations add value? Journal of Finance 59 (3): 1083-1124.

Kaniel, R., S. Liu, G. Saar, and S. Titman. 2008. Individual investor trading and return patterns around earnings announcements. Working paper, Cornell University.

Ke, B., and K. Petroni. 2004. How informed are actively trading institutional investors? Evidence from their trading behavior before a break in a string of consecutive earnings increases. Journal of Accounting Research 42 (5): 895-927.

Kim, O. 1993. Disagreements among shareholders over a firm's disclosure policy. Journal of Finance 48 (2): 747-760.

, and R. Verrecchia. 1994. Market liquidity and volume around earnings announcements. Journal of Accounting \& Economics 17 (1-2): 41-67.

, and 1997. Pre-announcement and event-period private information. Journal of Accounting \& Economics 24 (3): 395-419.

Koonce, L., M. Williamson, and J. Winchel. 2010. Consensus information and nonprofessional investors' reaction to the revelation of estimate inaccuracies. The Accounting Review 85 (3): 979-1000.

Kumar, A., and C. Lee. 2006. Retail investor sentiment and return comovements. The Journal of Finance 61 (5): 2451-2486.

Kyle, A. 1985. Continuous auctions and insider trading. Econometrica 53 (6): 1315-1335.

Lang, M., and R. Lundholm. 1996. Corporate disclosure policy and analyst behavior. The Accounting Review 71 (4): 467-492.

Larcker, D., and T. Rusticus. 2010. On the use of instrumental variables in accounting research. Journal of Accounting \& Economics 49 (3): 186-205.

Lee, C. 1992. Earnings news and small traders: An intraday analysis. Journal of Accounting \& Economics 15 (2-3): 265-302.

Lehavy, R., F. Li, and K. Merkley. 2010. The effect of annual report readability on analyst following and the properties of their earnings forecasts. The Accounting Review (Forthcoming).

Lerman, A. 2010. Individual investors' attention to accounting information: Message board discussions. Working Paper, Yale University.

Leuz, C., and R. Verrecchia. 2000. The economic consequences of increased disclosure. Journal of Accounting Research (Supplement): 91-124.

Lewis, M. 2010. The Big Short: Inside the Doomsday Machine. New York, NY: W.W. Norton \& Company.

Li, F. 2008. Annual report readability, current earnings, and earnings persistence. Journal of Accounting \& Economics 45 (2-3): 221-247.

Libby, R., J. Hunton, H. Tan, and N. Seybert. 2008. Relationship incentives and the optimistic/pessimistic pattern in analysts' forecasts. Journal of Accounting Research 46 (1): 173-198.

Malmendier, U., and G. Tate. 2005. CEO overconfidence and corporate investment. Journal of Finance 60 (6): 2661-2700.

, and 2008. Who makes acquisitions? CEO overconfidence and the market's reaction. Journal of Financial Economics 89 (1): 20-43.

, and D. Shanthikumar. 2007. Are small investors naïve about incentives? Journal of Financial Economics 85 (2): 457-489.

and 2009. Do security analysts speak to two tongues? Working paper, University of California at Berkeley.

Merton, R. 1987. A simple model of capital market equilibrium with incomplete information. Journal of Finance 42 (3): 483-510.

Messier, W., V. Owhoso, and C. Rakovski. 2008. Can audit partners predict subordinates' ability to detect errors. Journal of Accounting Research 46 (5): 1241-1264.

Mikhail. M., B. Walther, and R. Willis. 1997. Do security analysts improve their performance with experience? Journal of Accounting Research 35 (Supplement): 131-157. 
and 2004. Do security analysts exhibit persistent differences in stock picking ability? Journal of Financial Economics 74 (1): 67-91.

— - - 2007. When security analysts talk, who listens? The Accounting Review 82 (5): 1227-1253.

Miller, B. 2010. The effects of reporting complexity on small and large investor trading. The Accounting Review 85 (6): 2107-2144.

Odders-White, E. 2000. On the occurrence and consequences of inaccurate trade classification. Journal of Financial Markets 3 (3): 259-286.

Odean, T. 1998. Volume, volatility, price, and profit when all traders are above average. Journal of Finance 53 (6): 1887-1934.

Piotroski, J. 2000. Value investing: The use of historical financial statement information to separate winners from losers. Journal of Accounting Research 38 (Supplement): 1-41.

Securities and Exchange Commission (SEC). 2006. Electronic Filing and the EDGAR System: A Regulatory Overview. October 3, 2006. Available at: http://www.sec.gov/info/edgar/regoverview.htm.

- 2007. Speech by SEC Staff: Feedback from Individual Investors on Disclosure, January 19. Available at: http://www.sec.gov/news/speech/2007/spch011907ljs.htm.

- 2009. Announcement From the SEC Investor Advisory Committee. Press release, July 29, 2009.

Schipper, K. 1991. Analysts' forecasts. Accounting Horizons 5 (4): 105-131.

Statman, M., S. Thorley, and K. Vorkink. 2006. Investor overconfidence and trading volume. Review of Financial Studies 19 (4): 1531-1565.

Stickel,S. 1989. The timing of and incentives for annual earnings forecasts near interim earnings announcements. Journal of Accounting and Economics 11 (2-3): 275-292.

- 1992. Reputation and performance among security analysts. Journal of Finance 47 (5): 18111836.

1995. The anatomy of the performance of buy and sell recommendations. Financial Analysts Journal 51 (5): 25-39.

Taylor, D. 2009. Retail investors and the adjustment of stock prices to earnings information. Working Paper, Stanford University.

—, D. 2010. Individual investors and corporate earnings. Working Paper, University of Pennsylvania.

Verrecchia, R. 2001. Essays on disclosure. Journal of Accounting \& Economics 32 (1-3): 97-180.

Welker, M. 1995. Disclosure policy, information asymmetry and liquidity in equity markets. Contemporary Accounting Research 11 (2): 801-827.

Womack, K. 1996. Do brokerage analysts' recommendations have investment value? Journal of Finance 51 (1): 137-167. 


\section{APPENDIX A-Chapter 1 Variable Definitions}

\begin{tabular}{|c|c|c|}
\hline $\begin{array}{r}\text { HOLDINGS } \\
(\text { INDIVIDUALS') }\end{array}$ & $=$ & $\begin{array}{l}\text { Individual } i \text { 's one-year monthly averaged holdings of firm } j \text { ending } \\
\text { thirteen months after firm } j \text { 's fiscal year-end as a percentage of individual } \\
i \text { 's total averaged holdings during this same period-obtained from the } \\
\text { discount brokerage data; }\end{array}$ \\
\hline DISCLOSURE & $=$ & FOG_INV,LENGTH_INV, or AIMR_SCORE; \\
\hline FOG_INV & $=$ & $\begin{array}{l}-1 \mathrm{x} \text { (Fog Index of firm } j \text { 's } 10-\mathrm{K} \text { filing as per } \mathrm{Li}(2008) \text {, calculated as } 0.4 \\
\mathrm{x}(\text { average words per sentence + percentage of complex words) in fiscal } \\
\text { year } t) \text {; }\end{array}$ \\
\hline LENGTH_INV & $=$ & $\begin{array}{l}-1 \times \text { (natural logarithm of the word count of firm } j \text { 's } 10-\mathrm{K} \text { filing as per } \mathrm{Li} \\
(2008) \text { in fiscal year } t \text { ); }\end{array}$ \\
\hline AIMR_SCORE & $=$ & Industry rank-adjusted AIMR total disclosure score in fiscal year $t$ \\
\hline EQUITY & $=$ & $\begin{array}{l}\text { Natural logarithm of individual } i \text { 's one-year monthly averaged total } \\
\text { portfolio holdings ending thirteen months after firm } j \text { 's fiscal } t \text { year-end; }\end{array}$ \\
\hline LOGASSETS & $=$ & Natural logarithm of firm $j$ 's total assets for fiscal year $t$; \\
\hline$M T B$ & $=$ & $\begin{array}{l}\text { Market value of equity scaled by book value of equity of firm } j \text { in fiscal } \\
\text { year } t \text {; }\end{array}$ \\
\hline$S \& P 500$ & $=$ & " 1 " if firm $j$ is listed on the S\&P500 Index in fiscal year $t$, " 0 " otherwise; \\
\hline ANALYST & $=$ & $\begin{array}{l}\text { Natural logarithm of } 1 \text { plus the number of analysts following firm } j \text { in } \\
\text { I/B/E/S in fiscal year } t\end{array}$ \\
\hline SHAREHOLDERS & $=$ & $\begin{array}{l}\text { Natural logarithm of the total number of shareholders investing in firm } j \\
\text { (COMPUSTAT data item \#100) as of fiscal } t \text { 's year-end; }\end{array}$ \\
\hline$R O A$ & $=$ & $\begin{array}{l}\text { Net income before extraordinary items divided by total assets in fiscal } \\
\text { year } t \text {; }\end{array}$ \\
\hline$F F \_B E T A$ & $=$ & $\begin{array}{l}\text { Fama and French (1993) Beta for firm } j \text { calculated using daily returns } \\
\text { from one month to thirteen months after firm } j \text { 's fiscal } t \text { year-end; }\end{array}$ \\
\hline$R E T \_V O L$ & $=$ & Standard deviation of firm $j$ 's monthly stock returns in fiscal year $t-1$; \\
\hline$E A R N \_V O L$ & $=$ & $\begin{array}{l}\text { Standard deviation of firm } j \text { 's operating earnings in the past five fiscal } \\
\text { years scaled by total assets in fiscal year } t-1 \text {; }\end{array}$ \\
\hline$N B S E G$ & $=$ & $\begin{array}{l}\text { Natural logarithm of } 1 \text { plus the number of firm } j \text { 's business segments in } \\
\text { fiscal year } t \text {; }\end{array}$ \\
\hline$N G S E G$ & $=$ & $\begin{array}{l}\text { Natural logarithm of } 1 \text { plus the number of firm } j \text { 's geographic segments } \\
\text { in fiscal year } t \text {; }\end{array}$ \\
\hline NITEMS & $=$ & $\begin{array}{l}\text { Natural logarithm of } 1 \text { plus the number of missing items on } \\
\text { COMPUSTAT for firm } j \text { in fiscal year } t \text {; }\end{array}$ \\
\hline LOSS & $=$ & $\begin{array}{l}\text { " } 1 \text { " if net income before extraordinary items is negative in fiscal year } t \\
\text { and " } 0 \text { " otherwise; }\end{array}$ \\
\hline
\end{tabular}

(Continued) 


\section{APPENDIX A-Chapter 1 (continued)}

\begin{tabular}{|c|c|c|}
\hline OVERCONFIDENCE & $=$ & $\begin{array}{l}\text { Natural logarithm of the number of trades individual } i \text { made in all stocks } \\
\text { in the year ending thirteen months after firm } j \text { 's fiscal } t \text { year-end; }\end{array}$ \\
\hline HOLDINGS (INSITITUTIONS') & $=$ & $\begin{array}{l}\text { Institution } i \text { 's one-year quarterly averaged holdings of firm } j \text { ending } \\
\text { thirteen months after firm } j \text { 's fiscal year-end as a percentage of institution } \\
i \text { 's total averaged holdings during this same period-obtained from } \\
\text { Thomson-Reuters Institutional Holdings (13F) data; }\end{array}$ \\
\hline INSTITUTION & $=$ & $\begin{array}{l}\text { " } 1 \text { " if the HOLDINGS variable relates to an institution's holdings, " } 0 \text { " if } \\
\text { the HOLDINGS variable relates to an individual's holdings; }\end{array}$ \\
\hline$A B \_R E T U R N S$ & $=$ & $\begin{array}{l}\text { Using monthly positions following Barber and Odean (2000), as } \\
\text { individual } i \text { 's dollar return of firm } j \text {, net of trading commissions, minus } \\
\text { the dollar return on a value-weighted index of NYSE/AMEX/NASDAQ } \\
\text { stocks beginning one month to thirteen months after firm } j \text { 's fiscal year- } \\
\text { end, scaled by individual } i \text { 's averaged holdings of firm } j \text { during this } \\
\text { period; }\end{array}$ \\
\hline$F F_{-} E X C E S S$ & $=$ & $\begin{array}{l}\text { Carhart (1997) excess return for firm } j \text { calculated using daily returns } \\
\text { from one month to thirteen months after firm } j \text { 's fiscal } t \text { year-end; }\end{array}$ \\
\hline$F F \_S M B$ & $=$ & $\begin{array}{l}\text { Fama and French (1993) small minus big (SMB) market capitalization } \\
\text { risk factor coefficient for firm } j \text { calculated using daily returns from one } \\
\text { month to thirteen months after firm } j \text { 's fiscal } t \text { year-end; }\end{array}$ \\
\hline$F F_{-} H M L$ & $=$ & $\begin{array}{l}\text { Fama and French (1993) high minus low (HML) book-to-price ratio risk } \\
\text { factor coefficient for firm } j \text { calculated using daily returns from one month } \\
\text { to thirteen months after firm } j \text { 's fiscal } t \text { year-end; }\end{array}$ \\
\hline CARHART_MOMENTUM & $=$ & $\begin{array}{l}\text { Carhart }(1997) \text { momentum risk factor coefficient for firm } j \text { calculated } \\
\text { using daily returns from one month to thirteen months after firm } j \text { 's fiscal } \\
t \text { year-end; }\end{array}$ \\
\hline FIN_LITERACY & $=$ & " 1 " if individual $i$ is employed as a professional, " 0 " otherwise; \\
\hline SPECULATIVE & $=$ & $\begin{array}{l}\text { " } 1 \text { " if individual } i \text { reported their investment strategy upon account setup } \\
\text { as "speculation", " } 0 \text { " otherwise; }\end{array}$ \\
\hline STOCKS_HELD & $=$ & $\begin{array}{l}\text { Individual } i \text { 's monthly average of the number of stocks held beginning } \\
\text { one month to thirteen months after firm } j \text { 's fiscal } t \text { year-end; }\end{array}$ \\
\hline$A G E$ & $=$ & $\begin{array}{l}\text { Natural logarithm of individual } i \text { 's age upon the setup of the brokerage } \\
\text { account; }\end{array}$ \\
\hline FEMALE & $=$ & " 1 " if individual $i$ is female, " 0 " otherwise; \\
\hline FUNDAMENTAL & $=$ & Firm $j$ 's F-Score as per Piotroski (2000) multiplied by -1 ; \\
\hline$S I$ & $=$ & Firm $j$ 's special items scaled by book value of total assets in fiscal year $t$ \\
\hline$D A$ & $=$ & Firm $j$ 's performance-adjusted discretionary accruals; \\
\hline FIRM_AGE & $=$ & $\begin{array}{l}\text { Natural logarithm of the number of years that firm } j \text { is listed in the CRSP } \\
\text { monthly stock return files in fiscal year } t \text {; }\end{array}$ \\
\hline SALES_GROWTH & $=$ & $\begin{array}{l}\text { Firm } j \text { 's sales in fiscal year } t \text { minus sales in fiscal year } t-1 \text { divided by } \\
\text { sales in fiscal year } t-1 \text {; }\end{array}$ \\
\hline OP_MARGIN & $=$ & $\begin{array}{l}\text { Firm } j \text { 's sales in fiscal year } t \text { minus cost of goods sold in fiscal year } t \\
\text { divided by sales in fiscal year } t \text {; }\end{array}$ \\
\hline
\end{tabular}

(Continued) 


\section{APPENDIX A-Chapter 1 (continued)}

\begin{tabular}{|c|c|}
\hline$L O G \_H O L D I N G S$ & $\begin{array}{l}=\text { Natural logarithm of the averaged yearly holdings individual } i \text { invested in } \\
\text { firm } j \text { as of the thirteen months after firm } j \text { 's fiscal year-end; }\end{array}$ \\
\hline BR_OVERCON & $=" 1$ " if individual $i$ makes over 48 trades in any year, and " 0 " otherwise; \\
\hline AB_OVERCON & $\begin{aligned}= & \text { Error term from yearly regressions of } O V E R C O N F I D E N C E \text { on } \\
& \text { LOGEQUITY, FF_BETA, FF_SMB, FF_HML, CARHART } \\
& \text { MOMENTUM, and MTB; }\end{aligned}$ \\
\hline ANNUAL_REPORT & $\begin{array}{l}=\text { Industry rank-adjusted AIMR annual report disclosure score in fiscal } \\
\text { year } t \text {; }\end{array}$ \\
\hline INVESTOR_RELATIONS & $\begin{array}{l}=\text { Industry rank-adjusted AIMR investor relations disclosure score in fiscal } \\
\text { year } t \text {; and, }\end{array}$ \\
\hline OTHER_PUBLICATIONS & $\begin{array}{l}=\text { Industry rank-adjusted AIMR other publications disclosure score in fiscal } \\
\text { year } t \text {. }\end{array}$ \\
\hline
\end{tabular}




\section{APPENDIX B-Chapter 2 Variable Definitions}

\begin{tabular}{|c|c|c|}
\hline IN_LINE & $=$ & $\begin{array}{l}\text { " } 1 \text { " if individual } i \text { trades in firm } j \text { in line with analyst } q \text { 's guidance, " } 0 \text { " } \\
\text { otherwise. IN_LINE equals " } 1 \text { " if individual } i \text { trades in line with analyst q's } \\
\text { guidance, and " } 0 \text { " otherwise. For example, IN_LINE equals " } 1 \text { " when analyst } q \\
\text { issues a strong buy recommendation for firm } j \text { while the consensus } \\
\text { recommendation was a buy and individual } i \text { purchases the stock in days }-1 \text { to }+1 \\
\text { surrounding the recommendation announcement. Likewise for earnings } \\
\text { forecasts, IN_LINE equals " } 1 \text { " when analyst } q \text { issues an earnings forecast of } \\
\$ 2.00 \text { per share while the consensus earnings forecast for firm } j \text { was } \$ 1.80 \text { per } \\
\text { share and individual } i \text { purchases the stock in days }-1 \text { to }+1 \text { surrounding the } \\
\text { earnings forecast announcement. }\end{array}$ \\
\hline$A B S \_C H G$ & $=$ & $\begin{array}{l}\text { For recommendations: Absolute value of (analyst } q \text { 's recommendation for firm } j \text {, } \\
\text { on a scale from " } 1 \text { " (strong-buy) to " } 5 \text { " (strong-sell), minus the previous } \\
\text { consensus recommendation for firm } j \text { ); } \\
\text { For earnings forecasts: Absolute value of ( (analyst } q \text { 's earnings forecast for firm } j \\
\text { minus the previous consensus earnings forecast for firm } j \text { ) divided by the } \\
\text { previous consensus earnings forecast for firm } j \text { ); }\end{array}$ \\
\hline$U P G R A D E$ & $=$ & $\begin{array}{l}\text { For recommendations: " } 1 \text { " if analyst } q \text { 's recommendation is lower than the } \\
\text { previous consensus recommendation for firm } j \text { on a scale from " } 1 \text { " (strong-buy) } \\
\text { to " } 5 \text { " (strong-sell), " } 0 \text { " otherwise; } \\
\text { For earnings forecasts: " } 1 \text { " if analyst } q \text { 's earnings forecast for firm } j \text { is higher } \\
\text { than the previous consensus earnings forecast for firm } j, " 0 \text { " otherwise; }\end{array}$ \\
\hline DOWNGRADE & $=$ & $\begin{array}{l}\text { For recommendations: " } 1 \text { " if analyst } q \text { 's recommendation is higher than the } \\
\text { previous consensus recommendation for firm } j \text { on a scale from " } 1 \text { " (strong-buy) } \\
\text { to " } 5 \text { " (strong-sell), " } 0 \text { " otherwise; } \\
\text { For earnings forecasts: " } 1 \text { " if analyst } q \text { 's earnings forecast for firm } j \text { is lower than } \\
\text { the previous consensus earnings forecast for firm } j, \text { " } 0 \text { " otherwise; }\end{array}$ \\
\hline LOGMARKET & $=$ & $\begin{array}{l}\text { Natural logarithm of firm } j \text { 's total market value as of the most recent fiscal year- } \\
\text { end prior to analyst } q \text { 's guidance; }\end{array}$ \\
\hline$P / E$ & $=$ & $\begin{array}{l}\text { Price-to-earnings ratio for firm } j \text { as of the most recent fiscal year-end prior to } \\
\text { analyst } q \text { 's guidance; }\end{array}$ \\
\hline$R E T_{-} V O L$ & $=$ & $\begin{array}{l}\text { Firm } j \text { 's return volatility, calculated as the standard deviation of daily returns, in } \\
\text { the } 365 \text { days prior to analyst } q \text { 's guidance; }\end{array}$ \\
\hline$R A W_{-} R E T$ & $=$ & Firm $j$ 's raw returns in the 365 days prior to analyst $q$ 's guidance; \\
\hline BETA & $=$ & $\begin{array}{l}\text { Carhart (1997) beta for firm } j \text { calculated using daily returns in the } 365 \text { days prior } \\
\text { to analyst } q \text { 's guidance; }\end{array}$ \\
\hline$R O E$ & $=$ & $\begin{array}{l}\text { Net income before extraordinary items divided by common equity as of the most } \\
\text { recent fiscal year prior to analyst } q \text { 's guidance; }\end{array}$ \\
\hline ANALYST_PERF & $=$ & $\begin{array}{l}\text { Carhart's (1997) six month abnormal returns for all of analyst } q \text { 's } \\
\text { recommendations issued } 365 \text { to } 182 \text { days prior to the analyst's guidance; }\end{array}$ \\
\hline BROKER_SIZE & $=$ & $\begin{array}{l}\text { Number of analysts with analyst } q \text { 's brokerage firm that have made } \\
\text { recommendations in the } 365 \text { days prior to analyst } q \text { 's guidance; }\end{array}$ \\
\hline
\end{tabular}

(Continued) 


\section{APPENDIX A-Chapter 2 (continued)}

\begin{tabular}{|c|c|c|}
\hline$I N D \_E Q U I T Y$ & $=$ & $\begin{array}{l}\text { Individual } i \text { 's monthly averaged total equity holdings in the } 365 \text { days prior to } \\
\text { analyst } q \text { 's guidance; }\end{array}$ \\
\hline$T R A D E \_F R E Q$ & $=$ & $\begin{array}{l}\text { Natural logarithm of individual } i \text { 's total number of trades made in all equities in } \\
\text { the } 365 \text { days prior to analyst } q \text { 's guidance; }\end{array}$ \\
\hline$I N D \_P A S T \_R E T$ & $=$ & $\begin{array}{l}\text { Individual } i \text { 's portfolio return minus the return on a value-weighted index of } \\
\text { NYSE/AMEX/NASDAQ equities in the } 12 \text { months prior to analyst } q \text { 's guidance, } \\
\text { calculated using monthly positions following Barber and Odean (2000). }\end{array}$ \\
\hline GENDER & $=$ & " 1 " if individual $i$ is female, " 0 " otherwise; \\
\hline$A G E$ & $=$ & Individual $i$ 's age upon the setup of the brokerage account; \\
\hline RECOMMENDATION & $=$ & " 1 " if the analyst's guidance is a recommendation, "0" otherwise; \\
\hline FUT_RETURNS & $=$ & $\begin{array}{l}\text { Individual } i \text { 's six month return following the analyst guidance date } t \text { minus return } \\
\text { on a value-weighted index of NYSE/AMEX/NASDAQ stocks. For sell } \\
\text { transactions, the return is calculated as the abnormal returns by selling as } \\
\text { opposed to continuing holding the equity. For buy transactions, the return is } \\
\text { calculated until the original position is closed if sold within six months; }\end{array}$ \\
\hline FUT_BETA & & $\begin{array}{l}\text { Carhart (1997) beta for firm } j \text { calculated using daily returns from the six months } \\
\text { following analyst } q \text { 's guidance; }\end{array}$ \\
\hline$S M B$ & $=$ & $\begin{array}{l}\text { Fama and French (1993) small minus big (SMB) market capitalization risk factor } \\
\text { coefficient for firm } j \text { calculated using daily returns from the six months following } \\
\text { analyst } q \text { 's guidance; }\end{array}$ \\
\hline$H M L$ & $=$ & $\begin{array}{l}\text { Fama and French (1993) high minus low (HML) book-to-price ratio risk factor } \\
\text { coefficient for firm } j \text { calculated using daily returns from the six months following } \\
\text { analyst } q \text { 's guidance; and, }\end{array}$ \\
\hline CARHART_MOMENTUM & $=$ & $\begin{array}{l}\text { Carhart (1997) momentum risk factor coefficient for firm } j \text { calculated using daily } \\
\text { returns from the six months following analyst } q \text { 's guidance. }\end{array}$ \\
\hline
\end{tabular}




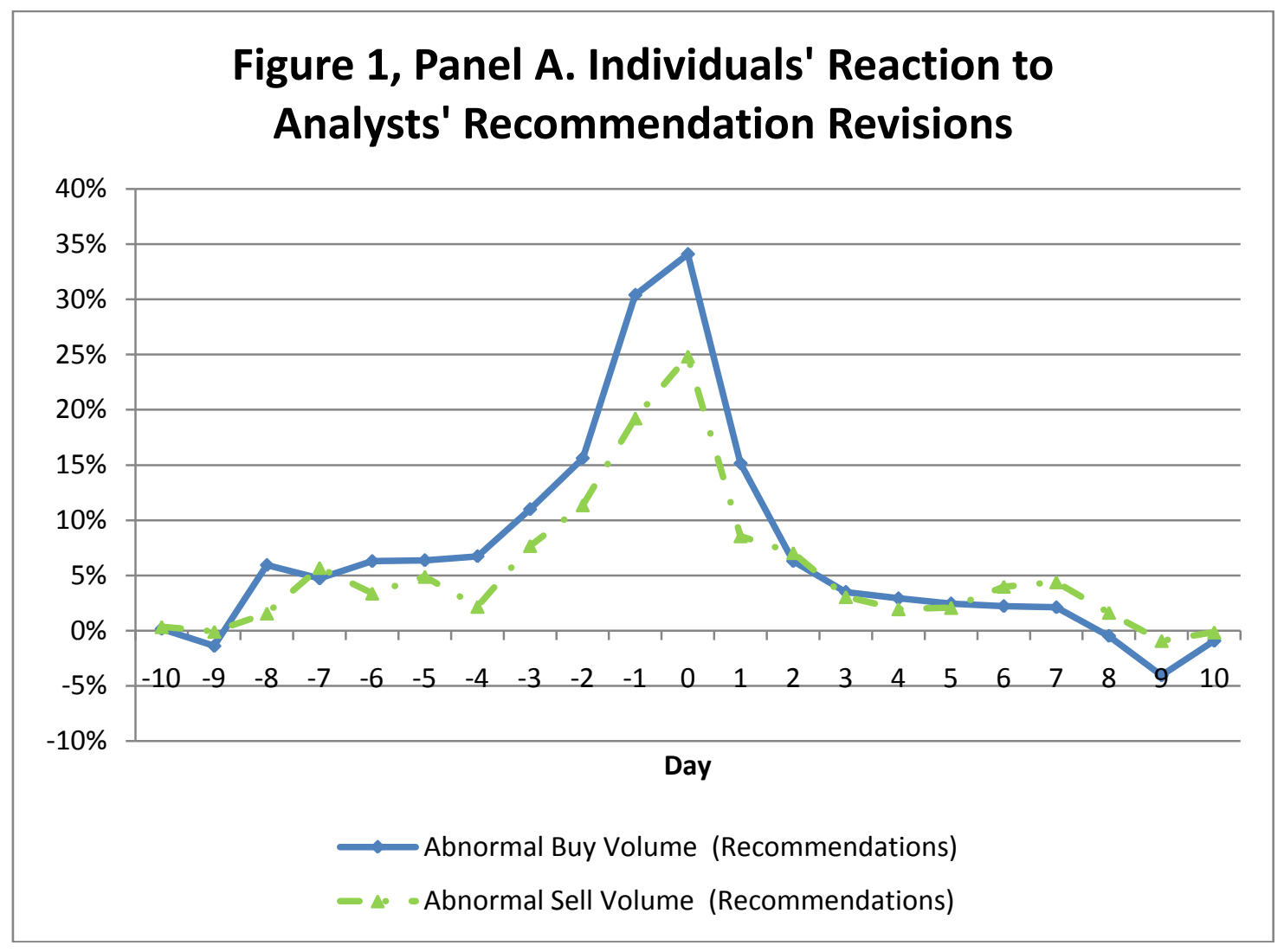

Figure 1, Panel A. Individuals' Reaction to Analysts' Recommendation Revisions. This figure plots individuals' aggregated reaction to 67,811 analysts' recommendations for 5,130 firms between October 1993 and December 1996. The y-axis represents individuals' abnormal trading activity as a percentage of their average trading volume in the fifteen days prior to the event window. The $\mathrm{x}$-axis represents the number of trading days from the recommendation announcement day as per I/B/E/S (day zero). T-statistics for event days -1 to 1 are all significant at the 0.01 level for both abnormal buy and sell volume. 


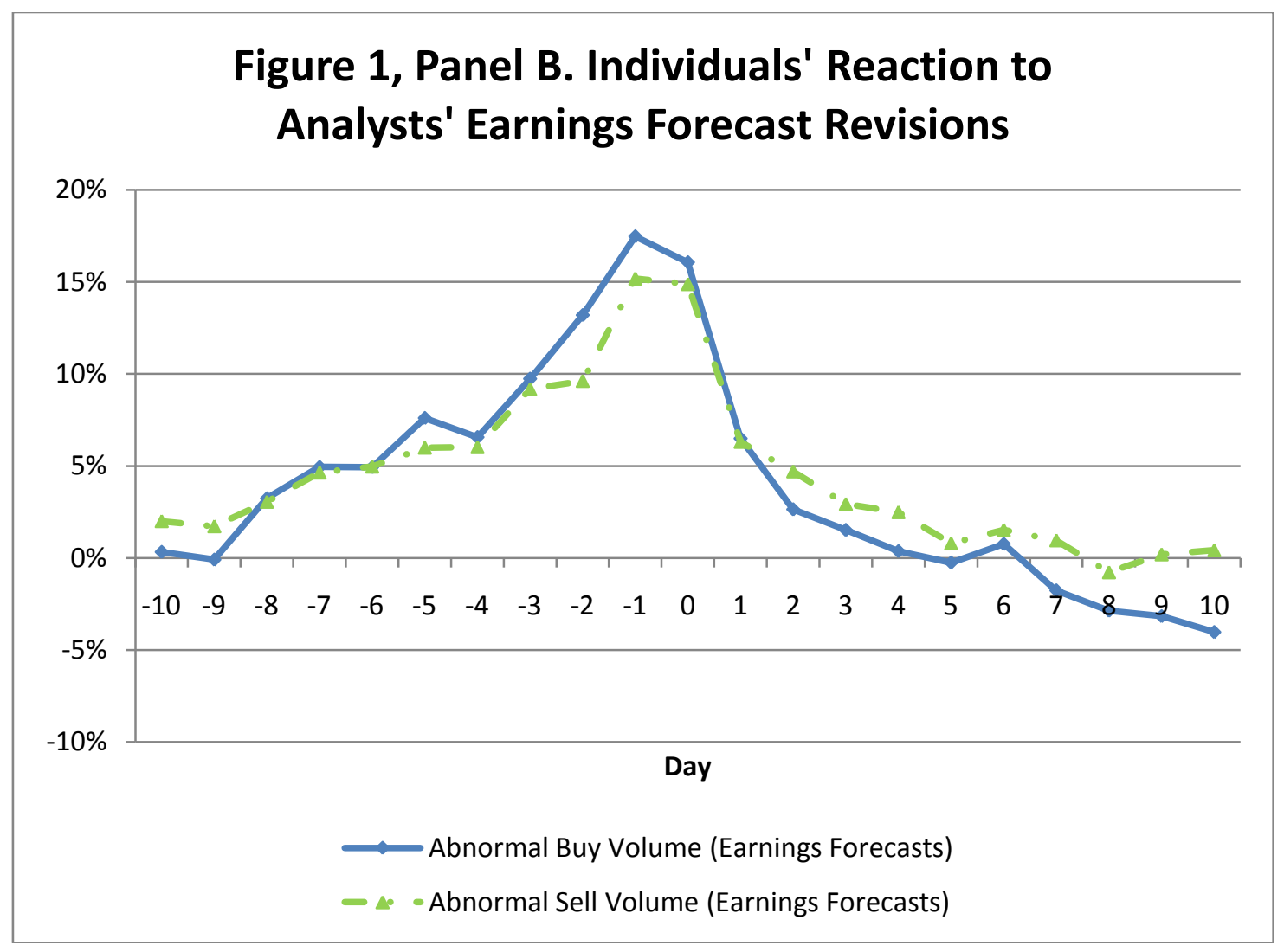

Figure 1, Panel B. Individuals' Reaction to Analysts' Earnings Forecast Revisions. This figure plots individuals' aggregated buy and sell reactions to 242,224 analysts' earnings forecast announcements for 5,407 firms between October 1993 and December 1996. The y-axis represents individuals' abnormal trading activity as a percentage of their average trading volume in the fifteen days prior to the event window. The $\mathrm{X}$-axis represents the number of trading days from the earnings forecast announcement day as per I/B/E/S (day zero). T-statistics for event days -1 to +1 are significant at the 0.01 level for both abnormal buy and sell volume. 


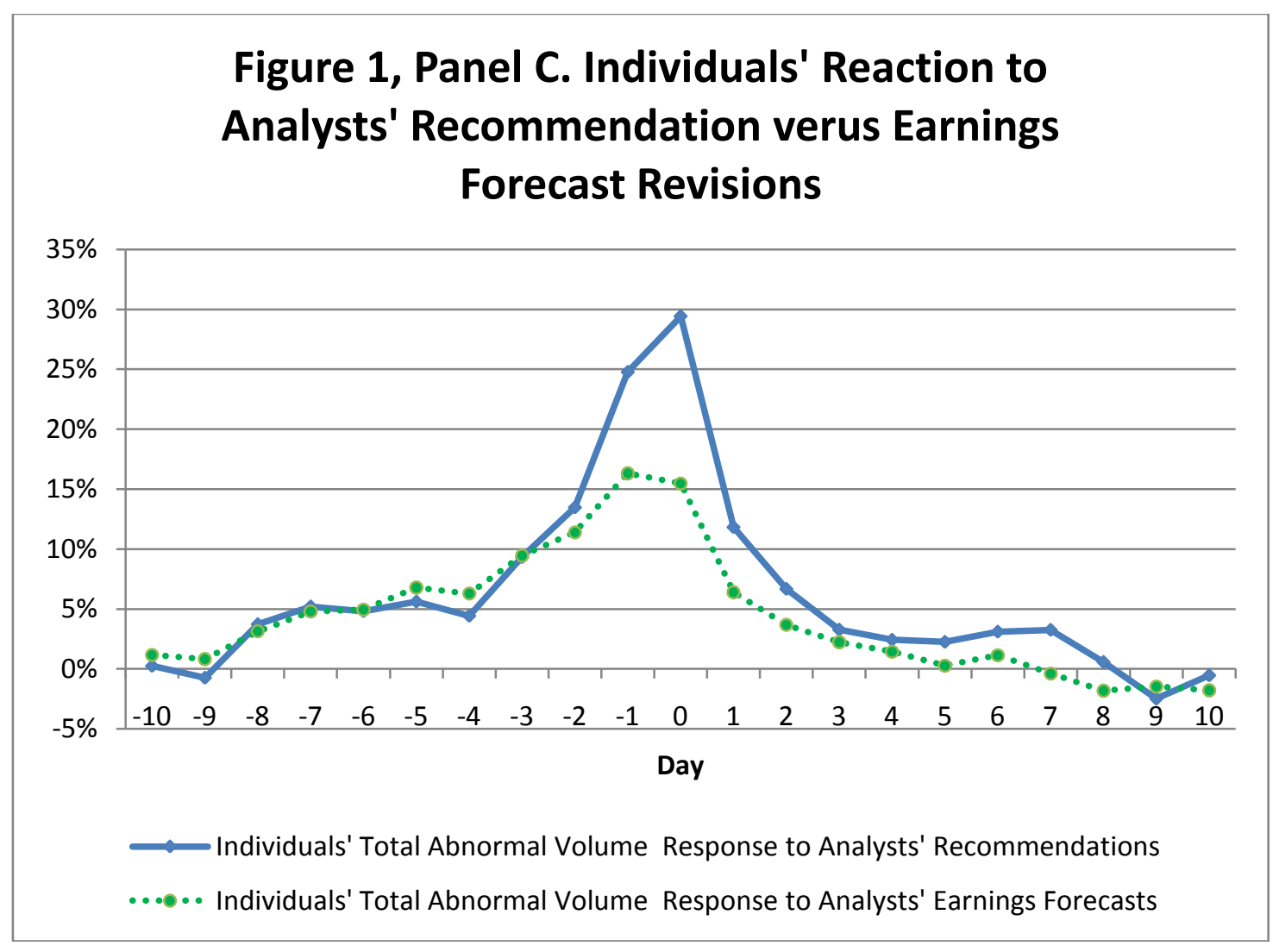

Figure 1, Panel C. Individuals' Relative Reaction to Analysts' Recommendation versus Earnings Forecast Revisions. This figure plots individuals' aggregated volume reaction to 67,811 analysts' recommendations and to 242,224 between October 1993 and December 1996. The y-axis represents individuals' abnormal trading activity as a percentage of their average trading volume in the fifteen days prior to the event window. The $\mathrm{x}$-axis represents the number of trading days from the recommendation or earnings forecast announcement day as per I/B/E/S (day zero). T-statistics for event days -1 to 1 are all significant at the 0.01 level, and differences between individuals' abnormal responses for recommendations and earnings forecasts are significant at the 0.01 level for event days -1 to +1 for both abnormal buy and sell volume. 


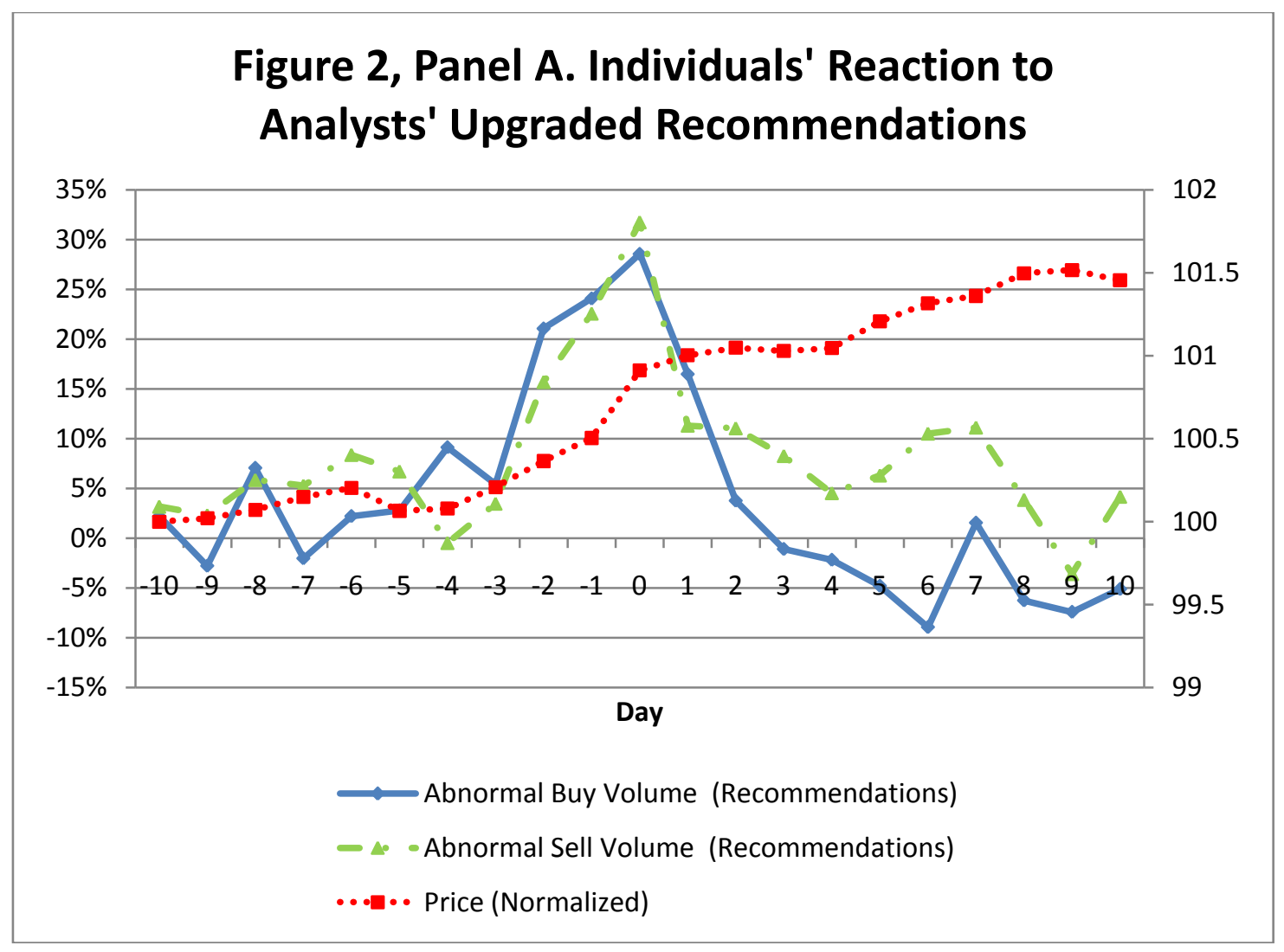

Figure 2, Panel A. Individuals' Reaction to Analysts' Upgraded Recommendations. This figure plots individuals' aggregated reaction to 20,486 analysts' upgraded recommendations for 3,438 firms between October 1993 and December 1996. The y-axis represents individuals' abnormal trading activity as a percentage of their average trading volume in the fifteen days prior to the event window. The $\mathrm{x}$-axis represents the number of trading days from the recommendation announcement day as per $\mathrm{I} / \mathrm{B} / \mathrm{E} / \mathrm{S}$ (day zero). Price is the average price of each event day normalized to 100 on day - 10 and is represented by the y-axis on the right. Price information is obtained from CRSP. Upgraded recommendations are those recommendations that are higher than the previous I/B/E/S consensus median recommendation. T-statistics for event days -1 to +1 are significant at the 0.01 level for both abnormal buy and sell volume. 


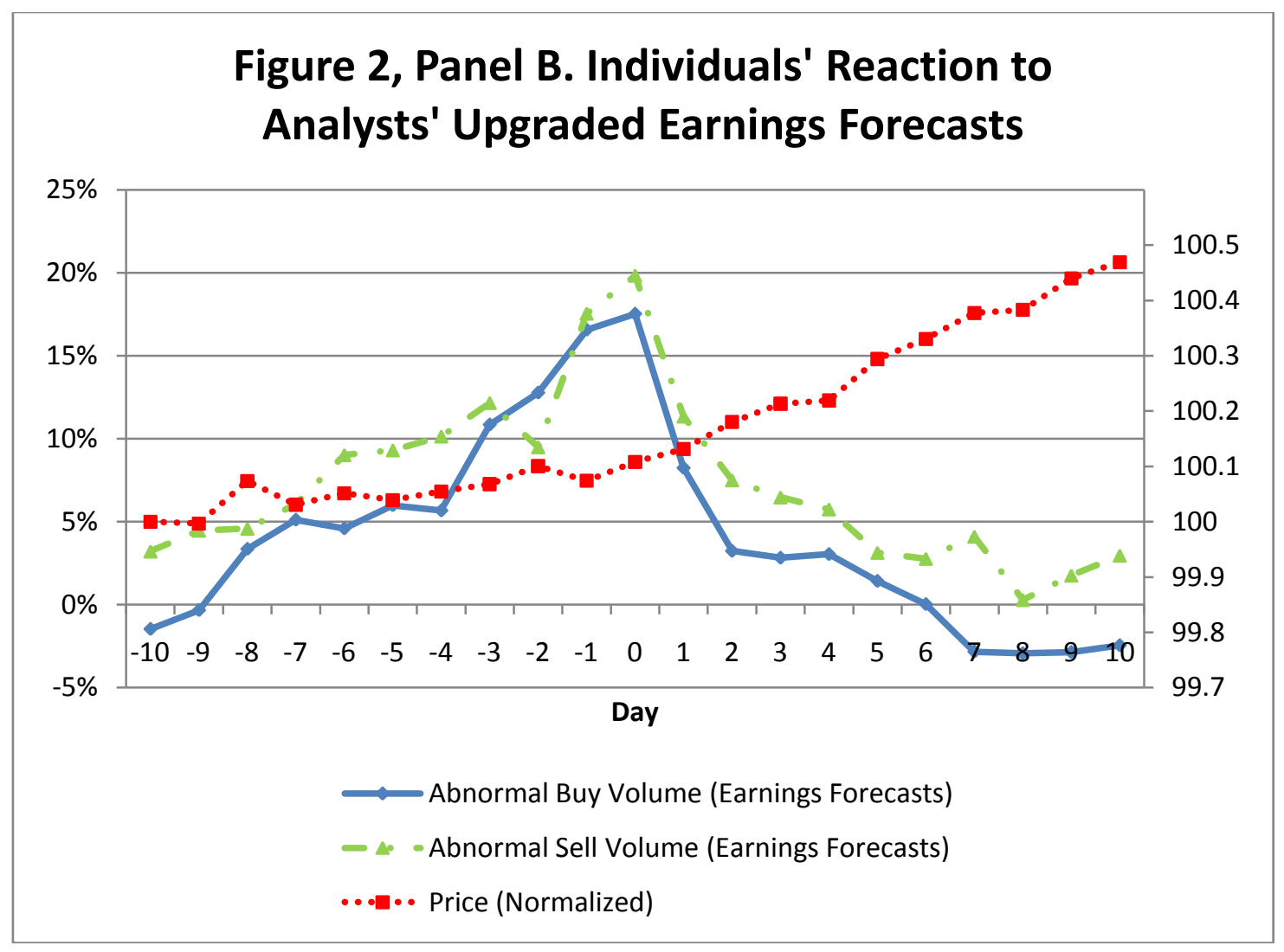

Figure 2, Panel B. Individuals' Reaction to Analysts' Upgraded Earnings Forecasts. This figure plots individuals' aggregated reaction to 89,133 analysts' upgraded earnings forecasts for 4,443 firms between October 1993 and December 1996. The y-axis represents individuals' abnormal trading activity as a percentage of their average trading volume in the fifteen days prior to the event window. The $\mathrm{x}$-axis represents the number of trading days from the earnings forecast announcement day as per I/B/E/S (day zero). Price is the average price of each event day normalized to 100 on day - 10 and is represented by the $y$-axis on the right. Price information is obtained from CRSP. Upgraded earnings forecasts are those earnings forecasts that are higher than the previous I/B/E/S consensus median earnings forecast. T-statistics for event days -1 to +1 are significant at the 0.01 level for both abnormal buy and sell volume. 


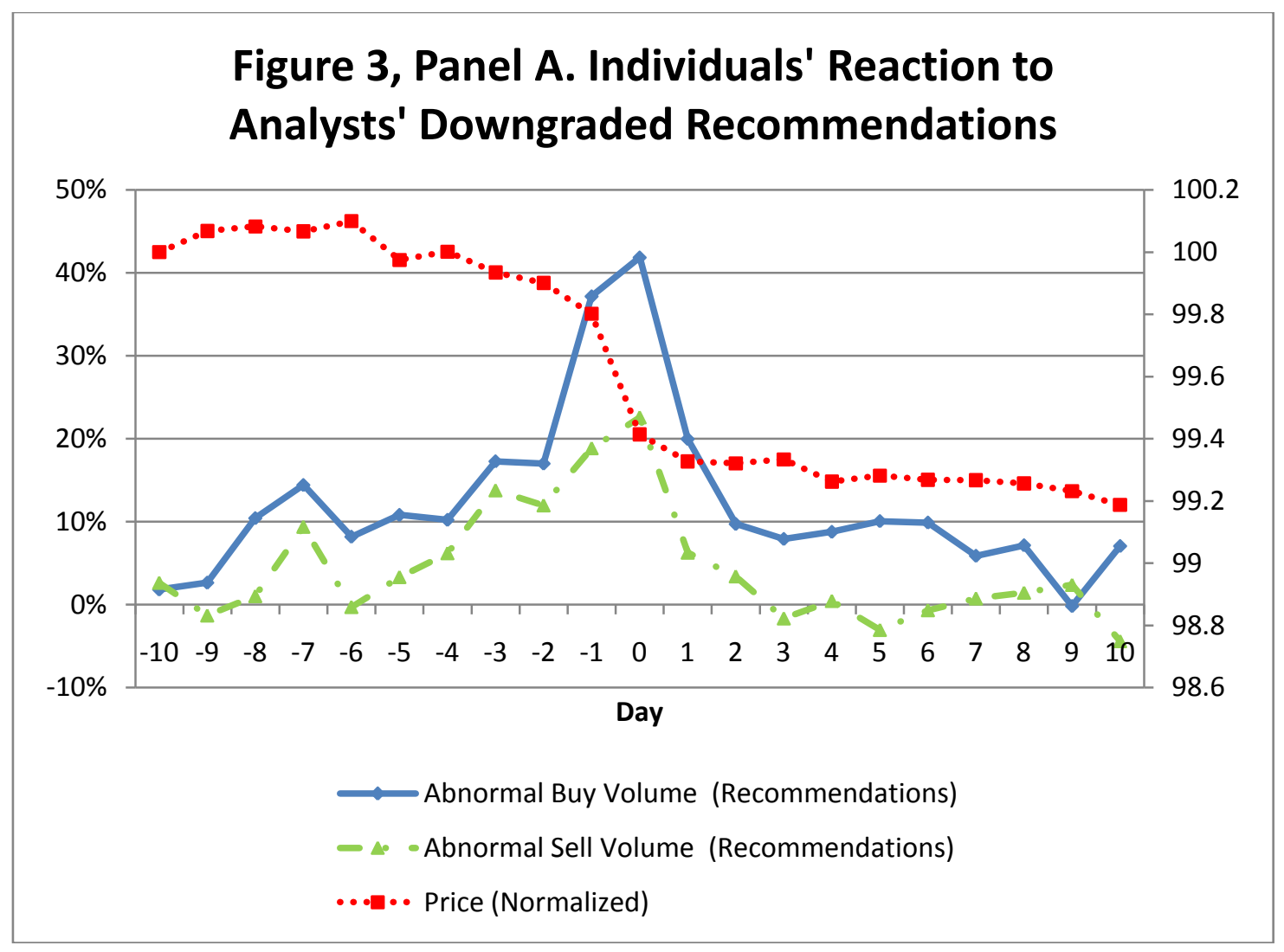

Figure 3, Panel A. Individuals' Reaction to Analysts' Downgraded Recommendations. This figure plots individuals' aggregated reaction to 27,403 analysts' downgraded recommendations for 4,733 firms between October 1993 and December 1996. The y-axis represents individuals' abnormal trading activity as a percentage of their average trading volume in the fifteen days prior to the event window. The $\mathrm{x}$-axis represents the number of trading days from the recommendation announcement day as per $\mathrm{I} / \mathrm{B} / \mathrm{E} / \mathrm{S}$ (day zero). Price is the average price of each event day normalized to 100 on day - 10 and is represented by the $\mathrm{y}$-axis on the right. Price information is obtained from CRSP. Downgraded recommendations are those recommendations that are lower than the previous I/B/E/S consensus median recommendation. T-statistics for event days -1 to +1 are significant at the 0.01 level for both abnormal buy and sell volume. 


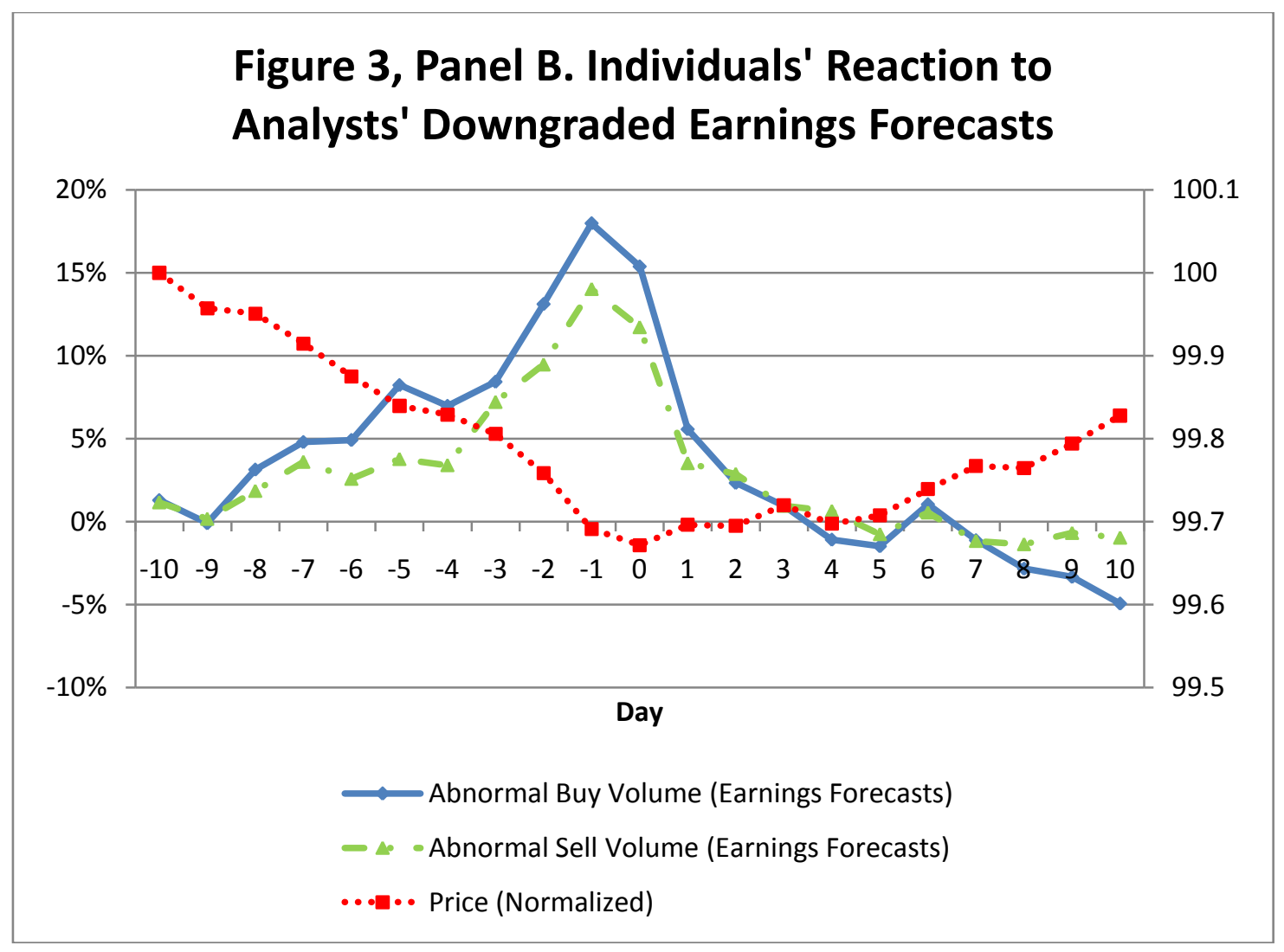

Figure 3, Panel B. Individuals' Reaction to Analysts' Downgraded Earnings Forecasts. This figure plots individuals' aggregated reaction to 149,798 analysts' downgraded earnings forecasts for 5,048 firms between October 1993 and December 1996. The y-axis represents individuals' abnormal trading activity as a percentage of their average trading volume in the fifteen days prior to the event window. The $\mathrm{x}$-axis represents the number of trading days from the earnings forecast announcement day as per I/B/E/S (day zero). Price is the average price of each event day normalized to 100 on day - 10 and is represented by the $\mathrm{y}$-axis on the right. Price information is obtained from CRSP. Downgraded earnings forecasts are those earnings forecasts that are lower than the previous I/B/E/S consensus median earnings forecast. T-statistics for event days -1 to +1 are significant at the 0.01 level for both abnormal buy and sell volume. 


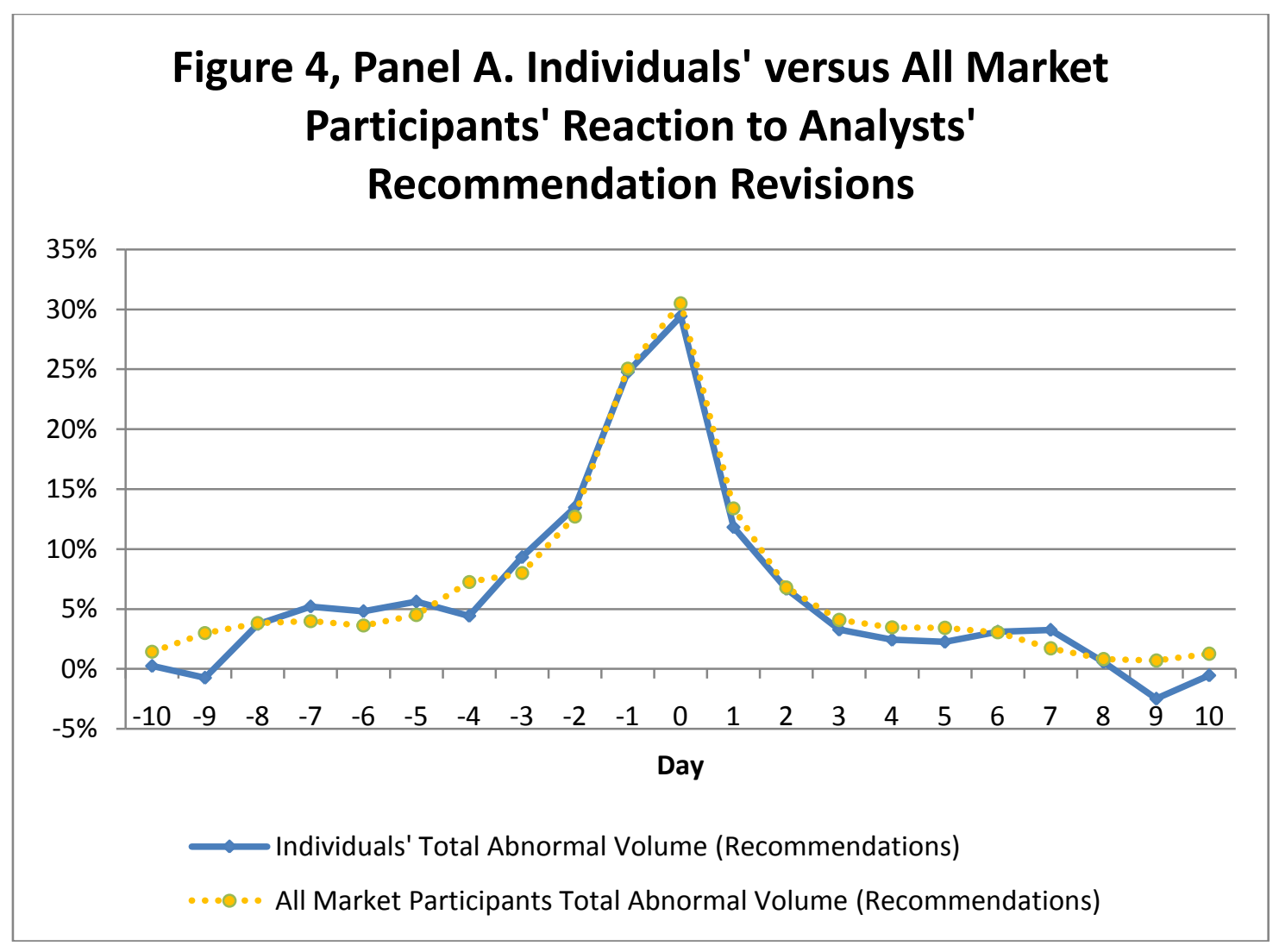

Figure 4, Panel A. Individuals' versus All Market Participants' Reaction to Analysts' Recommendation Revisions. This figure plots individuals' aggregated reaction and the market's reaction to 67,811 analysts' recommendations for 5,130 firms between October 1993 and December 1996. The y-axis represents each group's abnormal trading activity as a percentage of their respective average trading volume in the fifteen days prior to the event window. The $\mathrm{X}$-axis represents the number of trading days from the recommendation announcement day as per I/B/E/S (day zero). T-statistics for event days -1 to 1 are all significant at the 0.01 level for both groups. 


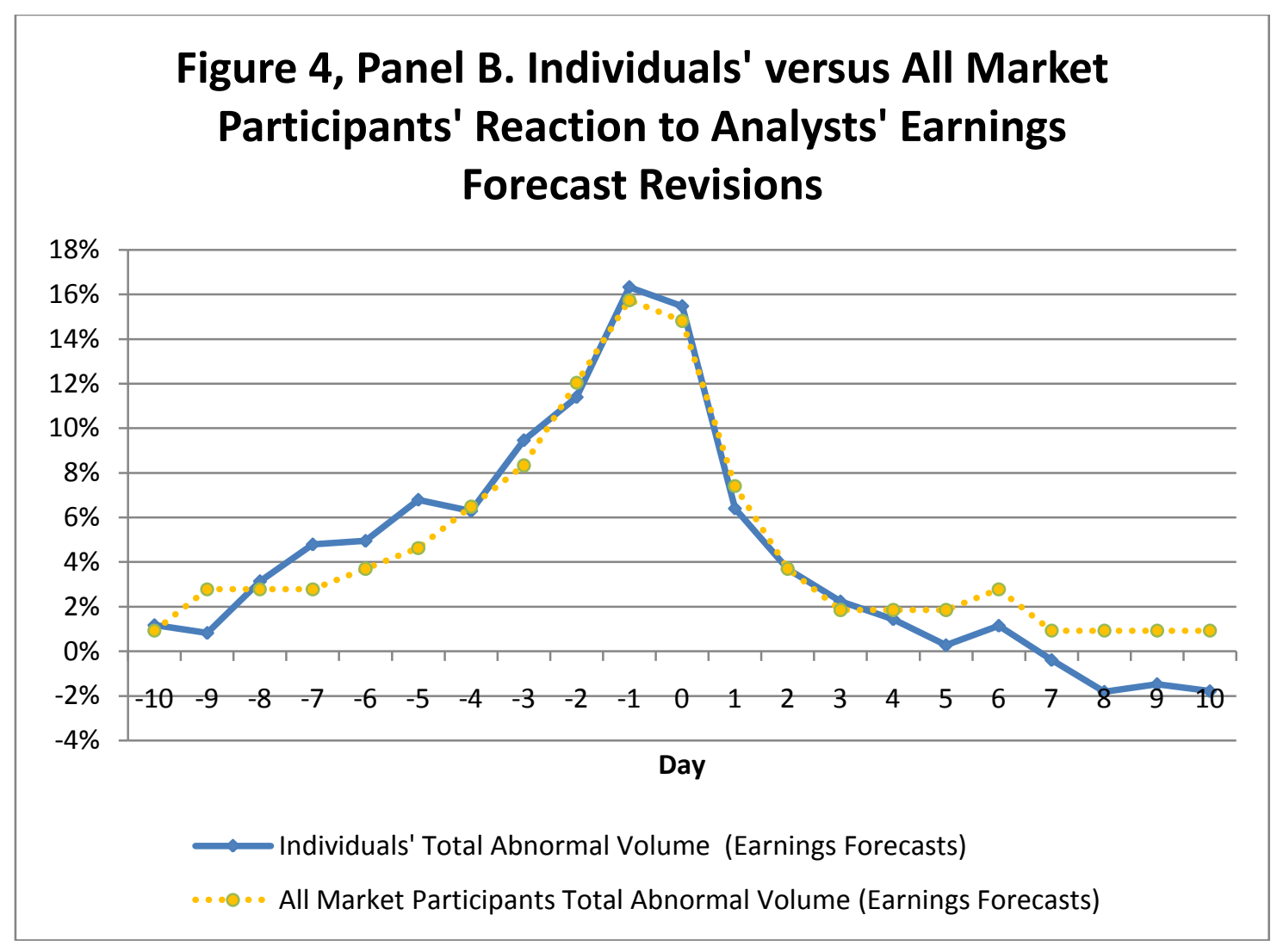

Figure 4, Panel B. Individuals' versus All Market Participants' Reaction to Analysts' Earnings Forecast Revisions. This figure plots individuals' aggregated reaction and the market's reaction to 242,224 analysts' earnings forecast announcements for 5,407 firms between October 1993 and December 1996. The y-axis represents each group's abnormal trading activity as a percentage of their respective average trading volume in the fifteen days prior to the event window. The $\mathrm{x}$-axis represents the number of trading days from the earnings forecast announcement day as per I/B/E/S (day zero). T-statistics for event days -1 to 1 are all significant at the 0.01 level for both groups. 
TABLE 1

Sample Selection Procedures

Annual Report Sample

Disclosure Score Sample

Individual account-firm-year observations with financial

disclosure data

95,107

272,432

Individual account-firm-year observations without the required COMPUSTAT and CRSP data

Total individual account-firm-year observations

91,228

249,888

(Total firm-year observations)

$(1,266)$

$(1,084)$

This table presents the sample selection procedures for the Annual Report and Disclosure Score Samples. 
TABLE 2

Panel A: Descriptive Statistics

\begin{tabular}{|c|c|c|c|c|c|c|c|c|}
\hline \multirow[b]{2}{*}{ Variable } & \multicolumn{4}{|c|}{ Annual Report Sample } & \multicolumn{4}{|c|}{ Disclosure Score Sample } \\
\hline & $\mathrm{N}$ & Mean & Median & STD & $\mathrm{N}$ & Mean & Median & STD \\
\hline$F O G_{-} I N V_{t}$ & 91,228 & -19.02 & -18.87 & 1.30 & & & & \\
\hline$L E N G T H \_I N V_{t}$ & 91,228 & -10.08 & -10.07 & 0.64 & & & & \\
\hline$A I M R \_S C O R E_{t}$ & & & & & 249,888 & 0.59 & 0.66 & 0.31 \\
\hline HOLDINGS $_{t+1}$ & 91,228 & 0.24 & 0.10 & 0.30 & 249,888 & 0.28 & 0.14 & 0.31 \\
\hline$E Q U I T Y_{t+1}$ & 91,228 & 10.44 & 10.43 & 1.67 & 249,888 & 10.20 & 10.12 & 1.57 \\
\hline LOGASSETS & 91,228 & 8.36 & 8.59 & 1.78 & 249,888 & 8.98 & 9.19 & 1.41 \\
\hline$M T B_{t}$ & 91,228 & 3.96 & 2.85 & 8.90 & 249,888 & 4.72 & 3.19 & 3.71 \\
\hline$S \& P 500_{t}$ & 91,228 & 0.57 & 1.00 & 0.50 & 249,888 & 0.67 & 1.00 & 0.47 \\
\hline$A N A L Y S T_{t}$ & 91,228 & 3.01 & 3.26 & 0.81 & 249,888 & 3.31 & 3.47 & 0.70 \\
\hline SHAREHOLDERS $_{t}$ & 91,228 & 3.28 & 3.38 & 1.86 & 249,888 & 4.13 & 4.22 & 1.45 \\
\hline$R O A_{t}$ & 91,228 & 0.08 & 0.07 & 0.10 & 249,888 & 0.08 & 0.07 & 0.08 \\
\hline$F F_{-} B E T A_{t+1}$ & 91,228 & 0.98 & 0.93 & 0.72 & 249,888 & 1.03 & 1.03 & 0.55 \\
\hline$R E T_{-} V O L_{t}$ & 91,228 & 0.09 & 0.08 & 0.04 & 249,888 & 0.08 & 0.07 & 0.03 \\
\hline$E A R N_{-} V O L_{t}$ & 91,228 & 0.05 & 0.03 & 0.05 & 249,888 & 0.04 & 0.03 & 0.03 \\
\hline$N B S E G_{t}$ & 91,228 & 0.99 & 0.69 & 0.42 & 249,888 & 1.15 & 1.10 & 0.48 \\
\hline$N G S E G_{t}$ & 91,228 & 1.31 & 1.39 & 0.25 & 249,888 & 1.36 & 1.39 & 0.24 \\
\hline NITEMS $_{t}$ & 91,228 & 5.09 & 5.08 & 0.11 & 249,888 & 5.02 & 5.01 & 0.14 \\
\hline $\operatorname{LOSS}_{t}$ & 91,228 & 0.06 & 0.00 & 0.23 & 249,888 & 0.14 & 0.00 & 0.34 \\
\hline OVER_CONFIDENCE $E_{t+1}$ & 91,228 & 1.69 & 1.61 & 1.37 & 249,888 & 1.57 & 1.39 & 1.25 \\
\hline
\end{tabular}

This table presents the descriptive statistics for the Annual Report and Disclosure Score Samples. See Appendix A for variable definitions. 
TABLE 2

Panel B: Pearson Correlation Matrix-Annual Report Sample

\begin{tabular}{|c|c|c|c|c|c|c|c|c|c|c|c|c|c|c|c|c|c|}
\hline & $\overline{F O G_{-} I N V}$ & $\begin{array}{l}\text { LENGTH }_{-} \\
\text {INV }\end{array}$ & $\overline{~ H O L D I N G S}$ & 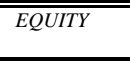 & $\begin{array}{l}L O G \\
\text { ASSETS } \\
\end{array}$ & 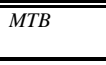 & 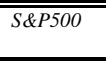 & "ANALYST & $\begin{array}{l}\text { SHARE } \\
\text { HOLDERS } \\
\end{array}$ & 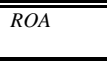 & 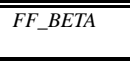 & $\begin{array}{l}R E T_{-} \\
V O L \\
\end{array}$ & $\begin{array}{l}\text { EARN } \\
\text { OOL } \\
\end{array}$ & (NBSEG & 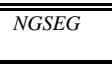 & "NITEMS & 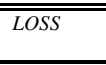 \\
\hline LENGTH_INV & $0.349^{*}$ & & & & & & & & & & & & & & & & \\
\hline HOLDINGS & $0.048^{*}$ & $0.009^{*}$ & & & & & & & & & & & & & & & \\
\hline EQUITY & $0.008^{*}$ & -0.001 & $-0.532 *$ & & & & & & & & & & & & & & \\
\hline LOGASSETS & $0.134^{*}$ & $-0.157^{*}$ & $0.010^{*}$ & $0.063^{*}$ & & & & & & & & & & & & & \\
\hline MTB & 0.003 & $-0.020^{*}$ & $0.018^{*}$ & 0.004 & $-0.063^{*}$ & & & & & & & & & & & & \\
\hline$S \& P 500$ & $0.164^{*}$ & $0.073^{*}$ & $0.096^{*}$ & $0.029 *$ & $0.450^{*}$ & $0.063 *$ & & & & & & & & & & & \\
\hline ANALYST & $0.102 *$ & $-0.084 *$ & $0.101 *$ & $0.050 *$ & $0.721^{*}$ & $0.073 *$ & $0.527 *$ & & & & & & & & & & \\
\hline $\begin{array}{c}\text { SHARE } \\
\text { HOLDERS }\end{array}$ & $0.180^{*}$ & $-0.110^{*}$ & $0.098^{*}$ & $0.023 *$ & $0.817 *$ & $-0.038^{*}$ & $0.345^{*}$ & $0.604 *$ & & & & & & & & & \\
\hline$R O A$ & $0.083 *$ & $0.063 *$ & $0.043 *$ & $0.049 *$ & $0.091^{*}$ & $-0.057^{*}$ & $0.368^{*}$ & $0.318^{*}$ & $0.019^{*}$ & & & & & & & & \\
\hline$F F \_B E T A$ & $-0.078^{*}$ & $-0.046^{*}$ & $-0.043^{*}$ & $-0.043^{*}$ & $-0.156^{*}$ & $-0.145^{*}$ & $-0.218^{*}$ & $-0.242 *$ & $-0.277 *$ & $-0.313^{*}$ & & & & & & & \\
\hline$R E T_{-} V O L$ & $-0.112 *$ & $0.019 *$ & $-0.036^{*}$ & $-0.098^{*}$ & $-0.488^{*}$ & $0.092 *$ & $-0.201 *$ & $-0.345^{*}$ & $-0.486^{*}$ & $-0.132 *$ & $0.296^{*}$ & & & & & & \\
\hline$E A R N_{-} V O L$ & $0.059 *$ & $-0.020^{*}$ & $0.016^{*}$ & $-0.045^{*}$ & $-0.319^{*}$ & $0.223 *$ & $0.056^{*}$ & $-0.100^{*}$ & $-0.282 *$ & $0.195^{*}$ & $-0.015^{*}$ & $0.389 *$ & & & & & \\
\hline NBSEG & $-0.106^{*}$ & $-0.203^{*}$ & $-0.019^{*}$ & $0.065^{*}$ & $0.282 *$ & $-0.051^{*}$ & $0.042 *$ & $0.015^{*}$ & $0.228^{*}$ & $-0.109^{*}$ & $-0.033^{*}$ & $-0.334 *$ & $-0.269^{*}$ & & & & \\
\hline NGSEG & $0.088^{*}$ & $-0.037^{*}$ & $0.066^{*}$ & $0.025^{*}$ & $0.363 *$ & -0.004 & $0.324 *$ & $0.367^{*}$ & $0.282^{*}$ & $0.144^{*}$ & $-0.183^{*}$ & $-0.022^{*}$ & $-0.030 *$ & $0.054 *$ & & & \\
\hline NITEMS & $0.013 *$ & $-0.036^{*}$ & $0.053^{*}$ & $-0.020^{*}$ & $-0.012 *$ & $0.043 *$ & $0.205 *$ & $0.061^{*}$ & $-0.007 *$ & $0.181^{*}$ & $-0.068^{*}$ & $-0.052^{*}$ & $0.125^{*}$ & $-0.072 *$ & $-0.141^{*}$ & & \\
\hline LOSS & $-0.070^{*}$ & $-0.031^{*}$ & $-0.031^{*}$ & $-0.058^{*}$ & $-0.215^{*}$ & $0.107 *$ & $-0.267 *$ & $-0.261^{*}$ & $-0.149^{*}$ & $-0.540 *$ & $0.176^{*}$ & $0.261 *$ & $0.054 *$ & $-0.054 *$ & $-0.101^{*}$ & $-0.119 *$ & \\
\hline $\begin{array}{l}\text { OVERCON }_{-} \\
\text {FIDENCE }\end{array}$ & $-0.021 *$ & $0.032^{*}$ & $-0.464 *$ & $0.449 *$ & $-0.117 *$ & $0.017^{*}$ & 0.006 & $-0.054 *$ & $-0.191 *$ & $0.079 *$ & $0.057^{*}$ & $0.115^{*}$ & $0.100^{*}$ & $-0.058^{*}$ & -0.006 & $-0.010^{*}$ & $-0.012 *$ \\
\hline
\end{tabular}

* indicate significance at the 0.05 level using two-tailed tests. See Appendix A for variable definitions. 
TABLE 2

Panel C: Pearson Correlation Matrix-Disclosure Score Sample

\begin{tabular}{|c|c|c|c|c|c|c|c|c|c|c|c|c|c|c|c|c|}
\hline & $\begin{array}{l}A I M R_{-} \\
\text {SCORE }\end{array}$ & "HOLDINGS & 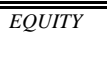 & $\begin{array}{l}\text { LOG } \\
\text { ASSETS }\end{array}$ & 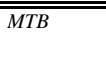 & S\&\&P500 & (ANALYST & $\begin{array}{l}\text { SHARE } \\
\text { HOLDERS }\end{array}$ & $\overline{R O A}$ & 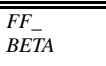 & $\begin{array}{l}E E T_{-} \\
\text {VOL }\end{array}$ & $\begin{array}{l}\text { EARN }_{-} \\
\text {VOL }\end{array}$ & 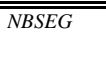 & 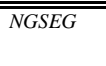 & "NITEMS & LOSS \\
\hline HOLDINGS & $0.075^{*}$ & & & & & & & & & & & & & & & \\
\hline EQUITY & $-0.016^{*}$ & $-0.533^{*}$ & & & & & & & & & & & & & & \\
\hline LOGASSETS & $0.264 *$ & $0.074 *$ & $0.036^{*}$ & & & & & & & & & & & & & \\
\hline мтв & $0.022 *$ & 0.003 & $-0.027^{*}$ & $-0.084^{*}$ & & & & & & & & & & & & \\
\hline$S \& P 500$ & $0.161^{*}$ & $0.094 *$ & $0.009 *$ & $0.354 *$ & $0.031 *$ & & & & & & & & & & & \\
\hline ANALYST & $0.042 *$ & $0.070^{*}$ & $0.032 *$ & $0.443 *$ & $0.015^{*}$ & $0.419 *$ & & & & & & & & & & \\
\hline $\begin{array}{l}\text { SHARE } \\
\text { HOLDER }\end{array}$ & $0.206^{*}$ & $0.095^{*}$ & $-0.021 *$ & $0.804 *$ & $-0.038^{*}$ & $0.381 *$ & $0.383 *$ & & & & & & & & & \\
\hline$R O A$ & $-0.059 *$ & $0.033^{*}$ & $0.038^{*}$ & $-0.112^{*}$ & $0.092 *$ & $0.353 *$ & $0.371^{*}$ & $-0.043 *$ & & & & & & & & \\
\hline$F F_{-} B E T A$ & $0.046^{*}$ & $0.010^{*}$ & $-0.057 *$ & $-0.013^{*}$ & $-0.025^{*}$ & $-0.058^{*}$ & $0.069 *$ & $-0.204 *$ & $-0.116^{*}$ & & & & & & & \\
\hline RET_VOL & $-0.083 *$ & $-0.032 *$ & $-0.057^{*}$ & $-0.502 *$ & $0.228 *$ & $-0.279 *$ & $-0.331 *$ & $-0.512 *$ & $-0.115^{*}$ & $0.307 *$ & & & & & & \\
\hline$E A R N_{-} V O L$ & $-0.208^{*}$ & $0.023 *$ & $-0.035^{*}$ & $-0.379 *$ & $0.100 *$ & $0.054 *$ & $0.079 *$ & $-0.269 *$ & $0.578^{*}$ & $0.016^{*}$ & $0.201 *$ & & & & & \\
\hline NBSEG & $0.020^{*}$ & $-0.078^{*}$ & $0.097 *$ & $0.363 *$ & $-0.029^{*}$ & $0.018^{*}$ & $0.048^{*}$ & $0.206^{*}$ & $-0.185^{*}$ & $-0.065^{*}$ & $-0.192^{*}$ & $-0.262^{*}$ & & & & \\
\hline NGSEG & $-0.166 *$ & $-0.017 *$ & $0.034 *$ & $0.253 *$ & $-0.019^{*}$ & $0.132 *$ & $0.231 *$ & $0.368 *$ & $0.184 *$ & $-0.264 *$ & $-0.292 *$ & $0.024 *$ & $0.092 *$ & & & \\
\hline NITEMS & $0.087^{*}$ & $0.011^{*}$ & $-0.031^{*}$ & $-0.038^{*}$ & $0.008 *$ & $-0.033^{*}$ & $-0.233^{*}$ & $-0.109^{*}$ & $-0.191^{*}$ & $0.038^{*}$ & 0.187 * & $-0.048^{*}$ & $0.033^{*}$ & $-0.433^{*}$ & & \\
\hline LOSS & $-0.095 *$ & $-0.005^{*}$ & $-0.072^{*}$ & 0.001 & $0.018^{*}$ & $-0.213^{*}$ & $-0.199 *$ & $0.046 *$ & $-0.580^{*}$ & $0.069 *$ & $0.103 *$ & $-0.148 *$ & $-0.028 *$ & 0.001 & $0.057^{*}$ & \\
\hline $\begin{array}{c}\text { OVERCON }_{-} \\
\text {FIDENCE }\end{array}$ & $-0.037 *$ & $-0.482 *$ & $0.422 *$ & $-0.092 *$ & -0.004 & $-0.033^{*}$ & $-0.026^{*}$ & $-0.134 *$ & $0.052 *$ & $0.037 *$ & $0.058 *$ & $0.061 *$ & $-0.011 *$ & 0.002 & -0.001 & $-0.013^{*}$ \\
\hline
\end{tabular}

* indicate significance at the 0.05 level using two-tailed tests. See Appendix A for variable definitions. 
TABLE 3

Individual Investors' Shareholdings and Financial Disclosure

\begin{tabular}{|c|c|c|c|c|c|c|c|}
\hline & \multicolumn{7}{|c|}{ Dependent Variable $=H O L D I N G S_{t+1}$} \\
\hline & I. & II. & III. & IV. & $\mathrm{V}$. & VI. & VII. \\
\hline$F O G_{-} I N V_{t}$ & $\begin{array}{c}0.005 * * * \\
(7.02)\end{array}$ & $\begin{array}{c}0.005 * * * \\
(6.19)\end{array}$ & & & & & $\begin{array}{c}0.004 * * * \\
(4.68)\end{array}$ \\
\hline$L E N G T H \_I N V_{t}$ & & & $\begin{array}{c}0.006 * * * \\
(4.47)\end{array}$ & $\begin{array}{c}\mathbf{0 . 0 0 8} * * * \\
(5.53)\end{array}$ & & & $\begin{array}{c}\mathbf{0 . 0 0 6}^{* * * *} \\
(3.74)\end{array}$ \\
\hline$A I M R \_S C O R E_{t}$ & & & & & $\begin{array}{c}0.024 * * * \\
(9.23)\end{array}$ & $\begin{array}{c}\mathbf{0 . 0 2 2} * * * \\
(\mathbf{8 . 5 1})\end{array}$ & \\
\hline$E Q U I T Y_{t+1}$ & $\begin{array}{c}-0.096 * * * \\
(-107.29)\end{array}$ & $\begin{array}{c}-0.097 * * * \\
(-107.31)\end{array}$ & $\begin{array}{c}-0.096 * * * \\
(-107.19)\end{array}$ & $\begin{array}{c}-0.097 * * * \\
(-107.24)\end{array}$ & $\begin{array}{c}-0.105 * * * \\
(-130.53)\end{array}$ & $\begin{array}{c}-0.105 * * * \\
(-130.18)\end{array}$ & $\begin{array}{c}-0.097 * * * \\
(-107.31)\end{array}$ \\
\hline LOGASSETS $_{t}$ & $\begin{array}{c}0.019 * * * \\
(14.02)\end{array}$ & $\begin{array}{c}0.017 * * * \\
(11.41)\end{array}$ & $\begin{array}{c}0.019 * * * \\
(14.24)\end{array}$ & $\begin{array}{c}0.018^{* * *} \\
(11.91)\end{array}$ & $\begin{array}{c}0.008 * * * \\
(5.00)\end{array}$ & $\begin{array}{c}0.011 * * * \\
(7.17)\end{array}$ & $\begin{array}{c}0.017 * * * \\
(11.58)\end{array}$ \\
\hline$M T B_{t}$ & $\begin{array}{c}0.001 * * * \\
(6.01)\end{array}$ & $\begin{array}{c}0.001 * * * \\
(5.67)\end{array}$ & $\begin{array}{c}0.001 * * * \\
(6.38)\end{array}$ & $\begin{array}{c}0.001 * * * \\
(5.87)\end{array}$ & $\begin{array}{c}-0.000 * * * \\
(-5.93)\end{array}$ & $\begin{array}{c}-0.000 * * * \\
(-3.37)\end{array}$ & $\begin{array}{c}0.001 * * * \\
(5.75)\end{array}$ \\
\hline$S \& P 500_{t}$ & $\begin{array}{c}0.015^{* * * *} \\
(5.30)\end{array}$ & $\begin{array}{c}0.009 * * * \\
(3.10)\end{array}$ & $\begin{array}{c}0.014 * * * \\
(5.16)\end{array}$ & $\begin{array}{c}0.008 * * * \\
(2.64)\end{array}$ & $\begin{array}{c}0.035 * * * \\
(14.87)\end{array}$ & $\begin{array}{c}0.035^{* * *} * \\
(14.45)\end{array}$ & $\begin{array}{c}0.008 * * * \\
(2.70)\end{array}$ \\
\hline$A N A L Y S T_{t}$ & $\begin{array}{l}0.001 \\
(0.34)\end{array}$ & $\begin{array}{l}0.001 \\
(0.48)\end{array}$ & $\begin{array}{l}-0.000 \\
(-0.05)\end{array}$ & $\begin{array}{l}0.000 \\
(0.22)\end{array}$ & $\begin{array}{c}0.015 * * * \\
(10.17)\end{array}$ & $\begin{array}{c}0.013 * * * \\
(8.63)\end{array}$ & $\begin{array}{l}0.002 \\
(0.75)\end{array}$ \\
\hline SHAREHOLDERS $_{t}$ & $\begin{array}{l}0.000 \\
(0.10)\end{array}$ & $\begin{array}{l}-0.000 \\
(-0.39)\end{array}$ & $\begin{array}{l}0.001 \\
(1.10)\end{array}$ & $\begin{array}{l}0.000 \\
(0.31)\end{array}$ & $\begin{array}{c}0.005 * * * \\
(3.78)\end{array}$ & $\begin{array}{c}0.003 * * \\
(2.29)\end{array}$ & $\begin{array}{l}-0.000 \\
(-0.33)\end{array}$ \\
\hline$R O A_{t}$ & $\begin{array}{c}0.101 * * * \\
(8.79)\end{array}$ & $\begin{array}{c}0.062 * * * \\
(5.07)\end{array}$ & $\begin{array}{c}0.106^{* * *} \\
(9.18)\end{array}$ & $\begin{array}{c}0.064 * * * \\
(5.19)\end{array}$ & $\begin{array}{c}0.211 * * * \\
(16.33)\end{array}$ & $\begin{array}{c}0.099 * * * \\
(6.00)\end{array}$ & $\begin{array}{c}0.062 * * * \\
(5.09)\end{array}$ \\
\hline$F F_{-} B E T A_{t+1}$ & $\begin{array}{c}-0.009 * * * \\
(-6.03)\end{array}$ & $\begin{array}{c}-0.006^{* * * *} \\
(-3.88)\end{array}$ & $\begin{array}{c}-0.009 * * * \\
(-5.85)\end{array}$ & $\begin{array}{c}-0.006 * * * \\
(-3.58)\end{array}$ & $\begin{array}{c}-0.031 * * * \\
(-20.07)\end{array}$ & $\begin{array}{c}-0.030 * * * \\
(-20.10)\end{array}$ & $\begin{array}{c}-0.006 * * * \\
(-3.77)\end{array}$ \\
\hline$R E T_{-} V O L_{t}$ & & $\begin{array}{c}-0.266 * * * \\
(-8.50)\end{array}$ & & $\begin{array}{c}-0.280 * * * \\
(-8.91)\end{array}$ & & $\begin{array}{c}-0.082 * * * \\
(-3.26)\end{array}$ & $\begin{array}{c}-0.267 * * * \\
(-8.51)\end{array}$ \\
\hline$E A R N_{-} V O L_{t}$ & & $\begin{array}{c}0.096 * * * \\
(4.23)\end{array}$ & & $\begin{array}{c}0.117 * * * \\
(5.11)\end{array}$ & & $\begin{array}{c}0.094 * * \\
(2.45)\end{array}$ & $\begin{array}{c}0.107 * * * \\
(4.67)\end{array}$ \\
\hline$N B S E G_{t}$ & & $\begin{array}{l}0.001 \\
(0.27)\end{array}$ & & $\begin{array}{l}0.000 \\
(0.12)\end{array}$ & & $\begin{array}{c}-0.022 * * * \\
(-10.06)\end{array}$ & $\begin{array}{l}0.002 \\
(0.70)\end{array}$ \\
\hline$N G S E G_{t}$ & & $\begin{array}{c}0.019 * * * \\
(3.90)\end{array}$ & & $\begin{array}{c}0.018 * * * \\
(3.67)\end{array}$ & & $\begin{array}{c}0.016 * * * \\
(2.84)\end{array}$ & $\begin{array}{c}0.019 * * * \\
(3.86)\end{array}$ \\
\hline NITEMS & & $\begin{array}{c}0.074 * * * \\
(7.55)\end{array}$ & & $\begin{array}{c}0.078 * * * \\
(7.95)\end{array}$ & & $\begin{array}{l}0.003 \\
(0.34)\end{array}$ & $\begin{array}{c}0.076 * * * \\
(7.81)\end{array}$ \\
\hline $\operatorname{LOSS}_{t}$ & & $\begin{array}{c}-0.009^{* *} \\
(-2.05)\end{array}$ & & $\begin{array}{c}-0.010^{* *} \\
(-2.19)\end{array}$ & & $\begin{array}{c}-0.019 * * * \\
(-8.45)\end{array}$ & $\begin{array}{c}-0.009^{* *} \\
(-2.01)\end{array}$ \\
\hline No. of Observations & 91,228 & 91,228 & 91,228 & 91,228 & 249,888 & 249,888 & 91,228 \\
\hline Adjusted $R^{2}$ & 0.31 & 0.32 & 0.31 & 0.32 & 0.31 & 0.31 & 0.32 \\
\hline
\end{tabular}

This table presents an analysis of the relation between individual investors' shareholdings and the following three financial disclosure measures: annual report readability $\left(F O G \_I N V\right)$, annual report length ( $\left.L E N G T H \_I N V\right)$, and analysts' disclosure scores (AIMR_SCORE). *,**, *** indicate significance at the 0.10, 0.05, and 0.01 levels, respectively, using two-tailed tests. $T$-statistics and $p$-values are calculated using clustered standard errors by individual investor account number. All regressions include year and industry fixed-effects; however, for brevity, these separate intercepts are not reported. See Appendix A for variable definitions. 
TABLE 4

Individual Investors' Overconfidence and Financial Disclosure

\begin{tabular}{|c|c|c|c|c|c|c|}
\hline & \multicolumn{6}{|c|}{ Dependent Variable $=H O L D I N G S_{t+1}$} \\
\hline & I. & II. & III. & IV. & V. & VI. \\
\hline$F O G_{-} I N V_{t}$ & $\begin{array}{l}0.005^{* * * *} \\
(6.70)\end{array}$ & $\begin{array}{l}0.010 * * * \\
(7.93)\end{array}$ & & & & \\
\hline $\begin{array}{l}\text { FOG_INV } \times \\
\text { OVERCONFIDENCE }\end{array}$ & & $\begin{array}{c}-0.003 * * * \\
(-6.95)\end{array}$ & & & & \\
\hline$L E N G T H \_I N V_{t}$ & & & $\begin{array}{l}0.009 * * * \\
(6.67)\end{array}$ & $\begin{array}{l}0.019 * * * \\
(6.98)\end{array}$ & & \\
\hline $\begin{array}{l}\text { LENGTH_INV } \times \\
\text { OVERCONFIDENCE }\end{array}$ & & & & $\begin{array}{c}-0.005 * * * \\
(-5.52)\end{array}$ & & \\
\hline$A I M R \_S C O R E_{t}$ & & & & & $\begin{array}{l}0.022 * * * \\
(8.95)\end{array}$ & $\begin{array}{c}0.066 * * * \\
(14.58)\end{array}$ \\
\hline $\begin{array}{l}\text { AIMR_SCORE } \times \\
\text { OVERCONFIDENCE } E_{t}\end{array}$ & & & & & & $\begin{array}{c}-0.027 * * * \\
(-15.85)\end{array}$ \\
\hline OVERCONFIDENCE $E_{t+1}$ & $\begin{array}{c}-0.061 * * * \\
(-44.51)\end{array}$ & $\begin{array}{c}-0.121 * * * \\
(-13.93)\end{array}$ & $\begin{array}{c}-0.061 * * * \\
(-44.48)\end{array}$ & $\begin{array}{c}-0.114 * * * \\
(-11.66)\end{array}$ & $\begin{array}{c}-0.078 * * * \\
(-42.94)\end{array}$ & $\begin{array}{c}-0.062 * * * \\
(-32.43)\end{array}$ \\
\hline$E Q U I T Y_{t+1}$ & $\begin{array}{c}-0.074 * * * \\
(-77.87)\end{array}$ & $\begin{array}{l}-0.074 * * * \\
(-77.83)\end{array}$ & $\begin{array}{c}-0.074 * * * \\
(-77.81)\end{array}$ & $\begin{array}{l}-0.074 * * * \\
(-77.78)\end{array}$ & $\begin{array}{c}-0.078 * * * \\
(-92.98)\end{array}$ & $\begin{array}{c}-0.078 * * * \\
(-93.03)\end{array}$ \\
\hline LOGASSETS $_{t}$ & $\begin{array}{c}0.018 * * * \\
(12.25)\end{array}$ & $\begin{array}{c}0.017 * * * \\
(11.99)\end{array}$ & $\begin{array}{c}0.018 * * * \\
(12.81)\end{array}$ & $\begin{array}{l}0.018 * * * \\
(12.71)\end{array}$ & $\begin{array}{c}0.014 * * * \\
(9.33)\end{array}$ & $\begin{array}{c}0.013 * * * \\
(8.86)\end{array}$ \\
\hline$M T B_{t}$ & $\begin{array}{c}0.001 * * * \\
(6.25)\end{array}$ & $\begin{array}{c}0.001 * * * \\
(6.20)\end{array}$ & $\begin{array}{c}0.001 * * * \\
(6.47)\end{array}$ & $\begin{array}{c}0.001 * * * \\
(6.51)\end{array}$ & $\begin{array}{c}-0.000 * * * \\
(-4.39)\end{array}$ & $\begin{array}{c}-0.000 * * * \\
(-4.74)\end{array}$ \\
\hline$S \& P 500_{t}$ & $\begin{array}{c}0.013^{* * *} \\
(4.66)\end{array}$ & $\begin{array}{c}0.012^{* * * *} \\
(4.53)\end{array}$ & $\begin{array}{c}0.011^{* * * *} \\
(4.08)\end{array}$ & $\begin{array}{c}0.011 * * * \\
(3.90)\end{array}$ & $\begin{array}{c}0.033 * * * \\
(14.62)\end{array}$ & $\begin{array}{c}0.034 * * * \\
(15.03)\end{array}$ \\
\hline$A N A L Y S T_{t}$ & $\begin{array}{l}0.003 \\
(1.52)\end{array}$ & $\begin{array}{l}0.003^{*} \\
(1.72)\end{array}$ & $\begin{array}{l}0.003 \\
(1.33)\end{array}$ & $\begin{array}{l}0.002 \\
(1.21)\end{array}$ & $\begin{array}{c}0.014^{* * *} \\
(9.14)\end{array}$ & $\begin{array}{l}0.014^{* * *} \\
(9.21)\end{array}$ \\
\hline SHAREHOLDERS $_{t}$ & $\begin{array}{c}-0.009 * * * \\
(-8.17)\end{array}$ & $\begin{array}{c}-0.009 * * * \\
(-7.94)\end{array}$ & $\begin{array}{c}-0.008 * * * \\
(-7.52)\end{array}$ & $\begin{array}{c}-0.008 * * * \\
(-7.23)\end{array}$ & $\begin{array}{c}-0.006 * * * \\
(-5.14)\end{array}$ & $\begin{array}{c}-0.006 * * * \\
(-4.90)\end{array}$ \\
\hline$R O A_{t}$ & $\begin{array}{c}0.098 * * * \\
(7.47)\end{array}$ & $\begin{array}{c}0.100 * * * \\
(7.62)\end{array}$ & $\begin{array}{c}0.100 * * * \\
(7.56)\end{array}$ & $\begin{array}{c}0.101 * * * \\
(7.65)\end{array}$ & $\begin{array}{c}0.164 * * * \\
(10.25)\end{array}$ & $\begin{array}{c}0.160 * * * \\
(10.01)\end{array}$ \\
\hline$F F \_B E T A_{t+1}$ & $\begin{array}{l}-0.002 \\
(-1.50)\end{array}$ & $\begin{array}{l}-0.002 \\
(-1.52)\end{array}$ & $\begin{array}{l}-0.002 \\
(-1.17)\end{array}$ & $\begin{array}{l}-0.001 \\
(-0.96)\end{array}$ & $\begin{array}{c}-0.023 * * * \\
(-15.02)\end{array}$ & $\begin{array}{c}-0.024 * * * \\
(-15.25)\end{array}$ \\
\hline$R E T_{-} V O L_{t}$ & $\begin{array}{c}-0.199 * * * \\
(-6.50)\end{array}$ & $\begin{array}{c}-0.194 * * * \\
(-6.34)\end{array}$ & $\begin{array}{c}-0.212 * * * \\
(-6.92)\end{array}$ & $\begin{array}{c}-0.210 * * * \\
(-6.85)\end{array}$ & $\begin{array}{l}-0.027 \\
(-1.10)\end{array}$ & $\begin{array}{l}-0.015 \\
(-0.59)\end{array}$ \\
\hline$E A R N_{-} V O L_{t}$ & $\begin{array}{c}0.119 * * * \\
(5.29)\end{array}$ & $\begin{array}{c}0.120 * * * \\
(5.35)\end{array}$ & $\begin{array}{c}0.142 * * * \\
(6.26)\end{array}$ & $\begin{array}{c}0.141 * * * \\
(6.22)\end{array}$ & $\begin{array}{c}0.098 * * * \\
(2.69)\end{array}$ & $\begin{array}{c}0.097 * * * \\
(2.68)\end{array}$ \\
\hline$N B S E G_{t}$ & $\begin{array}{l}-0.003 \\
(-1.29)\end{array}$ & $\begin{array}{l}-0.002 \\
(-0.89)\end{array}$ & $\begin{array}{l}-0.003 \\
(-1.35)\end{array}$ & $\begin{array}{l}-0.003 \\
(-1.34)\end{array}$ & $\begin{array}{c}-0.023 * * * \\
(-11.44)\end{array}$ & $\begin{array}{c}-0.023 * * * \\
(-11.19)\end{array}$ \\
\hline$N G S E G_{t}$ & $\begin{array}{c}0.019 * * * \\
(4.11)\end{array}$ & $\begin{array}{c}0.018 * * * \\
(3.90)\end{array}$ & $\begin{array}{c}0.018 * * * \\
(3.87)\end{array}$ & $\begin{array}{c}0.018 * * * \\
(3.95)\end{array}$ & $\begin{array}{c}0.032 * * * \\
(5.87)\end{array}$ & $\begin{array}{c}0.033 * * * \\
(6.08)\end{array}$ \\
\hline NITEMS $_{t}$ & $\begin{array}{c}0.073 * * * \\
(7.74)\end{array}$ & $\begin{array}{c}0.073 * * * \\
(7.72)\end{array}$ & $\begin{array}{c}0.077 * * * \\
(8.20)\end{array}$ & $\begin{array}{c}0.078 * * * \\
(8.29)\end{array}$ & $\begin{array}{l}0.002 \\
(0.19)\end{array}$ & $\begin{array}{l}0.005 \\
(0.56)\end{array}$ \\
\hline $\operatorname{LOSS}_{t}$ & $\begin{array}{l}-0.005 \\
(-1.03)\end{array}$ & $\begin{array}{l}-0.004 \\
(-0.90)\end{array}$ & $\begin{array}{l}-0.005 \\
(-1.15)\end{array}$ & $\begin{array}{l}-0.005 \\
(-1.17)\end{array}$ & $\begin{array}{c}-0.008 * * * \\
(-3.69)\end{array}$ & $\begin{array}{c}-0.008^{* * * *} \\
(-3.64)\end{array}$ \\
\hline No. of Observations & 91,228 & 91,228 & 91,228 & 91,228 & 249,888 & 249,888 \\
\hline Adjusted $R^{2}$ & 0.37 & 0.37 & 0.37 & 0.37 & 0.39 & 0.39 \\
\hline
\end{tabular}

This table presents an analysis of the relation between individual investors' overconfidence and the following three financial disclosure measures: annual report readability (FOG_INV), annual report length (LENGTH_INV), 
and analysts' disclosure scores (AIMR_SCORE).*,**,*** indicate significance at the $0.10,0.05$, and 0.01 levels, respectively, using two-tailed tests. $T$-statistics and $p$-values are calculated using clustered standard errors by individual investor account number. All regressions include year and industry fixed-effects; however, for brevity, these separate intercepts are not reported. See Appendix A for variable definitions. 
TABLE 5

Financial Disclosure: Individual versus Institutional Investors' Shareholdings

\begin{tabular}{|c|c|c|c|c|c|c|}
\hline & \multicolumn{6}{|c|}{ Dependent Variable $=H O L D I N G S_{t+1}$} \\
\hline & I. & II. & III. & IV. & $\mathrm{V}$. & VI. \\
\hline$F O G \_I N V_{t}$ & $\begin{array}{c}\mathbf{0 . 0 0 0 1} * * \\
(\mathbf{2 . 5 5})\end{array}$ & & & $\begin{array}{c}0.007 * * * \\
(8.99)\end{array}$ & & \\
\hline $\begin{array}{l}\text { FOG_INV } \times \\
\text { INSTITUTION }_{t}\end{array}$ & & & & $\begin{array}{c}-0.008 * * * \\
(-10.24)\end{array}$ & & \\
\hline$L E N G T H \_I N V_{t}$ & & $\begin{array}{c}0.0002 * * * \\
(4.53)\end{array}$ & & & $\begin{array}{c}0.003 * * \\
(2.20)\end{array}$ & \\
\hline $\begin{array}{l}\text { LENGTH_INV } \times \\
\text { INSTITUTION }_{t}\end{array}$ & & & & & $\begin{array}{l}-0.002 \\
(-1.23)\end{array}$ & \\
\hline$A I M R \_S C O R E_{t}$ & & & $\begin{array}{c}0.0003 * \\
(1.78)\end{array}$ & & & $\begin{array}{c}0.042 * * * \\
(14.59)\end{array}$ \\
\hline $\begin{array}{l}\text { AIMR_SCORE } \times \\
\text { INSTITUTION }_{t}\end{array}$ & & & & & & $\begin{array}{c}-0.052 * * * \\
(-18.40)\end{array}$ \\
\hline INSTITUTION & & & & $\begin{array}{c}-0.373 * * * \\
(-24.98)\end{array}$ & $\begin{array}{c}-0.242 * * * \\
(-15.08)\end{array}$ & $\begin{array}{r}-0.222 * * * \\
(-101.07)\end{array}$ \\
\hline LOGASSETS $_{t}$ & $\begin{array}{c}0.001 * * * \\
(23.29)\end{array}$ & $\begin{array}{c}0.001 * * * \\
(23.11)\end{array}$ & $\begin{array}{c}0.002 * * * \\
(17.58)\end{array}$ & $\begin{array}{c}0.006 * * * \\
(10.82)\end{array}$ & $\begin{array}{c}0.006 * * * \\
(11.76)\end{array}$ & $\begin{array}{c}0.004 * * * \\
(5.40)\end{array}$ \\
\hline$M T B_{t}$ & $\begin{array}{c}0.000 * * * \\
(5.18)\end{array}$ & $\begin{array}{c}0.000 * * * \\
(5.26)\end{array}$ & $\begin{array}{c}0.000 * * * \\
(11.93)\end{array}$ & $\begin{array}{c}0.000 * * \\
(2.51)\end{array}$ & $\begin{array}{c}0.000 * * * \\
(2.62)\end{array}$ & $\begin{array}{l}0.000 \\
(1.47)\end{array}$ \\
\hline$S \& P 500_{t}$ & $\begin{array}{c}0.001 * * * \\
(6.31)\end{array}$ & $\begin{array}{c}0.000^{* * * *} \\
(6.11)\end{array}$ & $\begin{array}{c}0.001 * * * \\
(4.73)\end{array}$ & $\begin{array}{c}0.002^{* *} \\
(2.34)\end{array}$ & $\begin{array}{c}0.002^{* *} \\
(2.13)\end{array}$ & $\begin{array}{c}0.016^{* * * *} \\
(14.93)\end{array}$ \\
\hline ANALYST $_{t}$ & $\begin{array}{c}-0.001 * * * \\
(-7.31)\end{array}$ & $\begin{array}{c}-0.001 * * * \\
(-7.25)\end{array}$ & $\begin{array}{l}-0.000 \\
(-0.32)\end{array}$ & $\begin{array}{c}-0.001 * \\
(-1.92)\end{array}$ & $\begin{array}{c}-0.002 * * * \\
(-2.72)\end{array}$ & $\begin{array}{c}0.004 * * * \\
(4.06)\end{array}$ \\
\hline SHAREHOLDERS $_{t}$ & $\begin{array}{c}0.000 * * * \\
(9.74)\end{array}$ & $\begin{array}{c}0.000 * * * \\
(9.97)\end{array}$ & $\begin{array}{c}0.000 * * * \\
(4.40)\end{array}$ & $\begin{array}{c}0.003 * * * \\
(7.84)\end{array}$ & $\begin{array}{c}0.003 * * * \\
(8.60)\end{array}$ & $\begin{array}{c}0.008 * * * \\
(12.89)\end{array}$ \\
\hline$R O A_{t}$ & $\begin{array}{c}0.006^{* * * *} \\
(9.68)\end{array}$ & $\begin{array}{c}0.005^{* * * *} \\
(9.50)\end{array}$ & $\begin{array}{c}0.024 * * * \\
(18.54)\end{array}$ & $\begin{array}{l}0.008 \\
(1.27)\end{array}$ & $\begin{array}{l}0.008 \\
(1.26)\end{array}$ & $\begin{array}{c}0.079 * * * \\
(7.82)\end{array}$ \\
\hline$F F \_B E T A_{t+1}$ & $\begin{array}{c}-0.001 * * * \\
(-11.56)\end{array}$ & $\begin{array}{c}-0.001 * * * \\
(-11.50)\end{array}$ & $\begin{array}{c}-0.001 * * * \\
(-11.52)\end{array}$ & $\begin{array}{c}-0.005 * * * \\
(-6.71)\end{array}$ & $\begin{array}{c}-0.005 * * * \\
(-6.58)\end{array}$ & $\begin{array}{c}-0.008 * * * \\
(-9.69)\end{array}$ \\
\hline$R E T_{-} V O L_{t}$ & $\begin{array}{l}0.000 \\
(0.10)\end{array}$ & $\begin{array}{l}0.000 \\
(0.52)\end{array}$ & $\begin{array}{c}-0.002 * * \\
(-1.97)\end{array}$ & $\begin{array}{l}-0.005 \\
(-0.35)\end{array}$ & $\begin{array}{l}-0.010 \\
(-0.77)\end{array}$ & $\begin{array}{c}-0.042 * * * \\
(-3.43)\end{array}$ \\
\hline$E A R N_{-} V O L_{t}$ & $\begin{array}{c}0.008 * * * \\
(9.95)\end{array}$ & $\begin{array}{c}0.008 * * * \\
(10.66)\end{array}$ & $\begin{array}{c}0.013 * * * \\
(6.49)\end{array}$ & $\begin{array}{c}0.051 * * * \\
(3.60)\end{array}$ & $\begin{array}{c}0.061 * * * \\
(4.35)\end{array}$ & $\begin{array}{c}0.178 * * * \\
(7.94)\end{array}$ \\
\hline$N B S E G_{t}$ & $\begin{array}{c}0.000 * * * \\
(4.05)\end{array}$ & $\begin{array}{c}0.000 * * * \\
(4.32)\end{array}$ & $\begin{array}{c}0.000 * * \\
(2.45)\end{array}$ & $\begin{array}{c}-0.007 * * * \\
(-7.37)\end{array}$ & $\begin{array}{c}-0.008 * * * \\
(-8.17)\end{array}$ & $\begin{array}{c}-0.025^{* * * *} \\
(-20.13)\end{array}$ \\
\hline$N G S E G_{t}$ & $\begin{array}{c}0.001 * * * \\
(4.16)\end{array}$ & $\begin{array}{c}0.001 * * * \\
(4.31)\end{array}$ & $\begin{array}{l}0.000 \\
(1.13)\end{array}$ & $\begin{array}{c}0.007 * * * \\
(3.67)\end{array}$ & $\begin{array}{c}0.007 * * * \\
(3.57)\end{array}$ & $\begin{array}{c}0.006^{* * *} \\
(2.42)\end{array}$ \\
\hline$N I T E M S_{t}$ & $\begin{array}{c}0.001 * * * \\
(3.94)\end{array}$ & $\begin{array}{c}0.001 * * * \\
(3.91)\end{array}$ & $\begin{array}{l}0.000 \\
(0.74)\end{array}$ & $\begin{array}{c}0.034 * * * \\
(9.18)\end{array}$ & $\begin{array}{c}0.035^{* * * *} \\
(9.47)\end{array}$ & $\begin{array}{l}0.002 \\
(0.58)\end{array}$ \\
\hline $\operatorname{LOSS}_{t}$ & $\begin{array}{c}0.000 * * * \\
(3.49)\end{array}$ & $\begin{array}{c}0.000 * * * \\
(3.20)\end{array}$ & $\begin{array}{c}0.001 * * * \\
(4.35)\end{array}$ & $\begin{array}{l}-0.001 \\
(-0.55)\end{array}$ & $\begin{array}{l}-0.001 \\
(-0.78)\end{array}$ & $\begin{array}{l}0.000 \\
(0.00)\end{array}$ \\
\hline No. of Observations & 175,468 & 175,468 & 289,489 & 266,696 & 266,696 & 539,377 \\
\hline Adjusted $R^{2}$ & 0.05 & 0.05 & 0.05 & 0.30 & 0.30 & 0.31 \\
\hline
\end{tabular}

This table presents an analysis examining whether individual and institutional investors differ in their use of financial disclosure using the following three financial disclosure measures: annual report readability $\left(F O G \_I N V\right)$, annual report length (LENGTH_INV), and analysts' disclosure scores (AIMR_SCORE). In Columns (I) to (III), the sample is restricted to institutional observations and in Columns (IV) to (VI), the 
sample includes both individual and institutional observations. *, **, *** indicate significance at the 0.10 , 0.05 , and 0.01 levels, respectively, using two-tailed tests. $T$-statistics and $p$-values are calculated using clustered standard errors by individual and institutional investors. All regressions include year and industry fixed-effects; however, for brevity, these separate intercepts are not reported. See Appendix A for variable definitions. 
TABLE 6

Investment Strategy and Financial Disclosure

\begin{tabular}{|c|c|c|c|}
\hline & \multicolumn{3}{|c|}{ Dependent Variable $=H O L D I N G S_{t+1}$} \\
\hline & I. & II. & III. \\
\hline$F O G_{-} I N V_{t}$ & $\begin{array}{c}0.005^{* * * *} \\
(5.24)\end{array}$ & & \\
\hline $\begin{array}{l}\text { FOG_INV } \times \\
\text { SPECULATIVE } E_{t}\end{array}$ & $\begin{array}{c}-0.006 * * \\
(-2.14)\end{array}$ & & \\
\hline$L E N G T H \_I N V_{t}$ & & $\begin{array}{c}0.008 * * * \\
(4.12)\end{array}$ & \\
\hline $\begin{array}{l}\text { LENGTH_INV } \times \\
\text { SPECULATIVE }\end{array}$ & & $\begin{array}{l}-0.010 * \\
(-1.73)\end{array}$ & \\
\hline$A I M R \_S C O R E_{t}$ & & & $\begin{array}{c}0.020 * * * \\
(5.70)\end{array}$ \\
\hline $\begin{array}{l}\text { AIMR_SCORE } \times \\
\text { SPECULATIVE }\end{array}$ & & & $\begin{array}{c}-0.034 * * * \\
(-2.70)\end{array}$ \\
\hline$S_{P E C U L A T I V E}$ & $\begin{array}{c}-0.116 * * \\
(-2.04)\end{array}$ & $\begin{array}{l}-0.097 \\
(-1.64)\end{array}$ & $\begin{array}{c}0.023 * * \\
(2.54)\end{array}$ \\
\hline$E Q U I T Y_{t+1}$ & $\begin{array}{c}-0.093 * * * \\
(-77.12)\end{array}$ & $\begin{array}{c}-0.093 * * * \\
(-77.04)\end{array}$ & $\begin{array}{c}-0.101 * * * \\
(-86.77)\end{array}$ \\
\hline LOGASSETS $_{t}$ & $\begin{array}{c}0.016 * * * \\
(8.29)\end{array}$ & $\begin{array}{c}0.017 * * * \\
(8.69)\end{array}$ & $\begin{array}{c}0.006 * * * \\
(2.59)\end{array}$ \\
\hline$M T B_{t}$ & $\begin{array}{c}0.001 * * * \\
(3.80)\end{array}$ & $\begin{array}{c}0.001 * * * \\
(3.98)\end{array}$ & $\begin{array}{c}-0.000 * \\
(-1.86)\end{array}$ \\
\hline$S \& P 500_{t}$ & $\begin{array}{c}0.007^{*} \\
(1.86)\end{array}$ & $\begin{array}{l}0.006 \\
(1.54)\end{array}$ & $\begin{array}{c}0.035 * * * \\
(11.12)\end{array}$ \\
\hline$A N A L Y S T_{t}$ & $\begin{array}{l}0.001 \\
(0.46)\end{array}$ & $\begin{array}{l}0.001 \\
(0.24)\end{array}$ & $\begin{array}{c}0.010 * * * \\
(4.65)\end{array}$ \\
\hline SHAREHOLDERS $_{t}$ & $\begin{array}{l}-0.000 \\
(-0.13)\end{array}$ & $\begin{array}{l}0.001 \\
(0.38)\end{array}$ & $\begin{array}{c}0.006 * * * \\
(3.46)\end{array}$ \\
\hline$R O A_{t}$ & $\begin{array}{c}0.072 * * * \\
(4.56)\end{array}$ & $\begin{array}{c}0.074 * * * \\
(4.65)\end{array}$ & $\begin{array}{c}0.099 * * * \\
(4.42)\end{array}$ \\
\hline$F F_{-} B E T A_{t+1}$ & $\begin{array}{c}-0.007 * * * \\
(-3.70)\end{array}$ & $\begin{array}{c}-0.007 * * * \\
(-3.52)\end{array}$ & $\begin{array}{c}-0.028 * * * \\
(-13.21)\end{array}$ \\
\hline$R E T_{-} V O L_{t}$ & $\begin{array}{c}-0.285^{* * * *} \\
(-6.93)\end{array}$ & $\begin{array}{c}-0.301 * * * \\
(-7.28)\end{array}$ & $\begin{array}{l}-0.058 \\
(-1.64)\end{array}$ \\
\hline$E A R N_{-} V O L_{t}$ & $\begin{array}{c}0.083 * * * \\
(2.82)\end{array}$ & $\begin{array}{c}0.106^{* * * *} \\
(3.54)\end{array}$ & $\begin{array}{l}0.053 \\
(1.02)\end{array}$ \\
\hline$N B S E G_{t}$ & $\begin{array}{l}0.002 \\
(0.75)\end{array}$ & $\begin{array}{l}0.002 \\
(0.57)\end{array}$ & $\begin{array}{c}-0.019 * * * \\
(-6.66)\end{array}$ \\
\hline$N G S E G_{t}$ & $\begin{array}{c}0.016 * * \\
(2.52)\end{array}$ & $\begin{array}{l}0.014^{* *} \\
(2.28)\end{array}$ & $\begin{array}{c}0.027 * * * \\
(3.46)\end{array}$ \\
\hline NITEMS $S_{t}$ & $\begin{array}{c}0.080 * * * \\
(6.40)\end{array}$ & $\begin{array}{c}0.084 * * * \\
(6.69)\end{array}$ & $\begin{array}{l}0.014 \\
(1.22)\end{array}$ \\
\hline $\operatorname{LOSS}_{t}$ & $\begin{array}{l}0.003 \\
(0.48)\end{array}$ & $\begin{array}{l}0.002 \\
(0.38)\end{array}$ & $\begin{array}{c}-0.020 * * * \\
(-6.36)\end{array}$ \\
\hline No. of Observations & 49,770 & 49,770 & 119,458 \\
\hline Adjusted $R^{2}$ & 0.33 & 0.33 & 0.33 \\
\hline
\end{tabular}

This table presents an analysis of the relation between individuals' investment strategy and the following three financial disclosure measures: annual report readability $\left(F O G_{-} I N V\right)$, annual report length 
$\left(\right.$ LENGTH_INV), and analysts' disclosure scores $\left(A I M R_{-} \_S C O R E\right) . *, * *, * * *$ indicate significance at the $0.10,0.05$, and 0.01 levels, respectively, using two-tailed tests. $T$-statistics and $p$-values are calculated using clustered standard errors by individual investor account number. See Appendix A for variable definitions. 
TABLE 7

Financial Literacy and Financial Disclosure

\begin{tabular}{|c|c|c|c|}
\hline & \multicolumn{3}{|c|}{ Dependent Variable $=H O L D I N G S_{t+1}$} \\
\hline & I. & II. & III. \\
\hline$F O G_{-} I N V_{t}$ & $\begin{array}{c}0.005 * * * \\
(3.11)\end{array}$ & & \\
\hline $\begin{array}{l}\text { FOG_INV } \times \\
\text { FIN_LITERACY }\end{array}$ & $\begin{array}{c}-0.004 * \\
(-1.70)\end{array}$ & & \\
\hline$L E N G T H \_I N V_{t}$ & & $\begin{array}{c}0.015^{* * * *} \\
(4.45)\end{array}$ & \\
\hline $\begin{array}{l}L E N G T H \_I N V \times \\
F I N \_L I T E R A C Y_{t}\end{array}$ & & $\begin{array}{c}-0.012 * * \\
(-2.40)\end{array}$ & \\
\hline$A I M R \_S C O R E_{t}$ & & & $\begin{array}{c}0.030 * * * \\
(4.87)\end{array}$ \\
\hline $\begin{array}{l}A I M R \_S C O R E \times \\
F I N_{2} L I T E R A C Y_{t}\end{array}$ & & & $\begin{array}{c}-0.021 * * \\
(-2.31)\end{array}$ \\
\hline FIN_LITERACY & $\begin{array}{l}-0.078 * \\
(-1.73)\end{array}$ & $\begin{array}{c}-0.118 * * \\
(-2.42)\end{array}$ & $\begin{array}{l}0.007 \\
(1.17)\end{array}$ \\
\hline$E Q U I T Y_{t+1}$ & $\begin{array}{c}-0.099 * * * \\
(-58.81)\end{array}$ & $\begin{array}{c}-0.099 * * * \\
(-58.71)\end{array}$ & $\begin{array}{c}-0.109 * * * \\
(-63.35)\end{array}$ \\
\hline LOGASSETS $_{t}$ & $\begin{array}{c}0.017 * * * \\
(6.25)\end{array}$ & $\begin{array}{c}0.017 * * * \\
(6.50)\end{array}$ & $\begin{array}{c}0.014 * * * \\
(4.78)\end{array}$ \\
\hline$M T B_{t}$ & $\begin{array}{c}0.001 * * * \\
(5.53)\end{array}$ & $\begin{array}{l}0.001 * * * \\
(5.63)\end{array}$ & $\begin{array}{l}-0.000 \\
(-1.44)\end{array}$ \\
\hline$S \& P 500_{t}$ & $\begin{array}{c}0.014 * * * \\
(2.71)\end{array}$ & $\begin{array}{c}0.012 * * \\
(2.36)\end{array}$ & $\begin{array}{c}0.038^{* * * *} \\
(8.47)\end{array}$ \\
\hline$A N A L Y S T_{t}$ & $\begin{array}{l}-0.003 \\
(-0.81)\end{array}$ & $\begin{array}{l}-0.003 \\
(-0.78)\end{array}$ & $\begin{array}{c}0.016 * * * \\
(5.49)\end{array}$ \\
\hline SHAREHOLDERS & $\begin{array}{l}0.001 \\
(0.70)\end{array}$ & $\begin{array}{l}0.002 \\
(0.97)\end{array}$ & $\begin{array}{l}-0.000 \\
(-0.17)\end{array}$ \\
\hline$R O A_{t}$ & $\begin{array}{c}0.097 * * * \\
(4.80)\end{array}$ & $\begin{array}{c}0.097 * * * \\
(4.80)\end{array}$ & $\begin{array}{l}0.108 * * * \\
(3.48)\end{array}$ \\
\hline$F F \_B E T A_{t+l}$ & $\begin{array}{c}-0.006^{* *} \\
(-1.99)\end{array}$ & $\begin{array}{l}-0.005^{*} \\
(-1.87)\end{array}$ & $\begin{array}{c}-0.031 * * * \\
(-11.13)\end{array}$ \\
\hline$R E T_{-} V O L_{t}$ & $\begin{array}{c}-0.309 * * * \\
(-5.51)\end{array}$ & $\begin{array}{c}-0.314 * * * \\
(-5.61)\end{array}$ & $\begin{array}{c}-0.114 * * \\
(-2.36)\end{array}$ \\
\hline$E A R N_{-} V O L_{t}$ & $\begin{array}{l}0.028 \\
(0.77)\end{array}$ & $\begin{array}{l}0.049 \\
(1.36)\end{array}$ & $\begin{array}{l}0.091 \\
(1.28)\end{array}$ \\
\hline$N B S E G_{t}$ & $\begin{array}{l}0.004 \\
(0.88)\end{array}$ & $\begin{array}{l}0.005 \\
(1.07)\end{array}$ & $\begin{array}{c}-0.019 * * * \\
(-4.79)\end{array}$ \\
\hline$N G S E G_{t}$ & $\begin{array}{c}0.015^{*} \\
(1.73)\end{array}$ & $\begin{array}{l}0.015^{*} \\
(1.70)\end{array}$ & $\begin{array}{c}0.012 \\
(1.08)\end{array}$ \\
\hline$N_{I T E M S}$ & $\begin{array}{c}0.093 * * * \\
(5.22)\end{array}$ & $\begin{array}{l}0.098 * * * \\
(5.51)\end{array}$ & $\begin{array}{l}0.001 \\
(0.08)\end{array}$ \\
\hline $\operatorname{LOSS}_{t}$ & $\begin{array}{l}-0.007 \\
(-0.91)\end{array}$ & $\begin{array}{l}-0.008 \\
(-0.94)\end{array}$ & $\begin{array}{c}-0.019 * * * \\
(-4.61)\end{array}$ \\
\hline No. of Observations & 27,909 & 27,909 & 75,322 \\
\hline Adjusted $R^{2}$ & 0.32 & 0.32 & 0.31 \\
\hline
\end{tabular}

This table presents an analysis of the relation between individual investors' financial literacy and the following three financial disclosure measures: annual report readability $\left(F O G_{-} I N V\right)$, annual report length $\left(L E N G T H \_I N V\right)$, and analysts' disclosure scores (AIMR_SCORE). *,**, *** indicate significance at the 
$0.10,0.05$, and 0.01 levels, respectively, using two-tailed tests. $T$-statistics and $p$-values are calculated using clustered standard errors by individual investor account number. See Appendix A for variable definitions. 
TABLE 8

Individual Investors' Excess Returns and Financial Disclosure

\begin{tabular}{|c|c|c|c|}
\hline & \multicolumn{3}{|c|}{ Dependent Variable $=A B \_R E T U R N S_{\mathrm{t}+1}$} \\
\hline & I. & II. & III. \\
\hline$F O G_{-} I N V_{t}$ & $\begin{array}{c}0.020 * * * \\
(12.15)\end{array}$ & & \\
\hline$L E N G T H \_I N V_{t}$ & & $\begin{array}{c}0.033 * * * \\
(9.78)\end{array}$ & \\
\hline$A I M R \_S C O R E_{t}$ & & & $\begin{array}{c}0.017 * * \\
(1.97)\end{array}$ \\
\hline$E_{Q U I T Y}{ }_{t+1}$ & $\begin{array}{l}0.005 \\
(0.91)\end{array}$ & $\begin{array}{l}0.005 \\
(0.93)\end{array}$ & $\begin{array}{c}0.007 * \\
(1.89)\end{array}$ \\
\hline LOGASSETS $_{t}$ & $\begin{array}{c}0.062 * * * \\
(14.52)\end{array}$ & $\begin{array}{c}0.066^{* * * *} \\
(15.23)\end{array}$ & $\begin{array}{c}-0.038 * * * \\
(-9.88)\end{array}$ \\
\hline$M T B_{t}$ & $\begin{array}{c}0.004 * * * \\
(9.42)\end{array}$ & $\begin{array}{c}0.004 * * * \\
(9.71)\end{array}$ & $\begin{array}{c}-0.002 * * * \\
(-33.21)\end{array}$ \\
\hline$S \& P 500_{t}$ & $\begin{array}{c}-0.015^{* *} \\
(-2.42)\end{array}$ & $\begin{array}{c}-0.021 * * * \\
(-3.33)\end{array}$ & $\begin{array}{c}0.027 * * * \\
(3.69)\end{array}$ \\
\hline$A N A L Y S T_{t}$ & $\begin{array}{c}-0.108 * * * \\
(-17.35)\end{array}$ & $\begin{array}{c}-0.110 * * * \\
(-17.84)\end{array}$ & $\begin{array}{l}0.004 \\
(1.27)\end{array}$ \\
\hline SHAREHOLDERS $_{t}$ & $\begin{array}{l}0.004 \\
(1.14)\end{array}$ & $\begin{array}{c}0.007 * * \\
(2.09)\end{array}$ & $\begin{array}{c}0.024 * * * \\
(5.53)\end{array}$ \\
\hline$R O A_{t}$ & $\begin{array}{c}0.095^{* *} \\
(2.52)\end{array}$ & $\begin{array}{c}0.102 * * * \\
(2.71)\end{array}$ & $\begin{array}{c}-1.363 * * * \\
(-15.13)\end{array}$ \\
\hline$F F_{-} B E T A_{t+1}$ & $\begin{array}{c}0.041 * * * \\
(5.10)\end{array}$ & $\begin{array}{c}0.041 * * * \\
(5.11)\end{array}$ & $\begin{array}{l}-0.003 \\
(-0.48)\end{array}$ \\
\hline$R E T_{-} V O L_{t}$ & $\begin{array}{c}-1.295^{* * *} \\
(-13.24)\end{array}$ & $\begin{array}{c}-1.348 * * * \\
(-13.79)\end{array}$ & $\begin{array}{c}0.621 * * * \\
(8.90)\end{array}$ \\
\hline$E A R N_{-} V O L_{t}$ & $\begin{array}{c}1.023 * * * \\
(14.03)\end{array}$ & $\begin{array}{c}1.112 * * * \\
(15.06)\end{array}$ & $\begin{array}{c}1.902 * * * \\
(14.16)\end{array}$ \\
\hline$N B S E G_{t}$ & $\begin{array}{c}0.015^{* * *} \\
(2.59)\end{array}$ & $\begin{array}{c}0.014 * * \\
(2.33)\end{array}$ & $\begin{array}{c}0.028 * * * \\
(5.50)\end{array}$ \\
\hline$N G S E G_{t}$ & $\begin{array}{c}-0.094 * * * \\
(-7.91)\end{array}$ & $\begin{array}{c}-0.100 * * * \\
(-8.41)\end{array}$ & $\begin{array}{c}0.121 * * * \\
(11.86)\end{array}$ \\
\hline$N I T E M S_{t}$ & $\begin{array}{l}-0.024 \\
(-1.01)\end{array}$ & $\begin{array}{l}-0.009 \\
(-0.39)\end{array}$ & $\begin{array}{c}0.234 * * * \\
(12.99)\end{array}$ \\
\hline $\operatorname{LOSS}_{t}$ & $\begin{array}{c}0.071 * * * \\
(5.07)\end{array}$ & $\begin{array}{c}0.069 * * * \\
(4.93)\end{array}$ & $\begin{array}{c}-0.090 * * * \\
(-7.07)\end{array}$ \\
\hline$F F \_S M B$ & $\begin{array}{c}-0.023 * * * \\
(-3.17)\end{array}$ & $\begin{array}{c}-0.022 * * * \\
(-3.00)\end{array}$ & $\begin{array}{c}0.050 * * * \\
(5.48)\end{array}$ \\
\hline$F F \_H M L$ & $\begin{array}{c}-0.013 * * * \\
(-3.09)\end{array}$ & $\begin{array}{c}-0.013 * * * \\
(-2.98)\end{array}$ & $\begin{array}{c}0.033 * * * \\
(5.00)\end{array}$ \\
\hline CARHART_MOMENTUM & $\begin{array}{c}0.128 * * * \\
(32.71)\end{array}$ & $\begin{array}{c}0.130 * * * \\
(33.22)\end{array}$ & $\begin{array}{c}0.118 * * * \\
(20.46)\end{array}$ \\
\hline No. of Observations & 91,228 & 91,228 & 249,888 \\
\hline Adjusted $R^{2}$ & 0.06 & 0.06 & 0.03 \\
\hline
\end{tabular}

This table presents an analysis of the relation between individual investors' excess returns and the following three financial disclosure measures: annual report readability $\left(F O G_{-} I N V\right)$, annual report length $\left(L E N G T H \_I N V\right)$, and analysts' disclosure scores $\left(A I M R \_S C O R E\right)$. *,**, *** indicate significance at the $0.10,0.05$, and 0.01 levels, respectively, using two-tailed tests. $T$-statistics and $p$-values are calculated using clustered standard errors by individual investor account number. See Appendix A for variable definitions. 
TABLE 9

Information Environment and Financial Disclosure

\begin{tabular}{|c|c|c|c|}
\hline & \multicolumn{3}{|c|}{ Dependent Variable $=H O L D I N G S_{t+1}$} \\
\hline & I. & II. & III. \\
\hline$F O G_{-} I N V_{t}$ & $\begin{array}{c}0.022 * * * \\
(4.17)\end{array}$ & & \\
\hline $\begin{array}{l}F O G_{1} I N V \times \\
F U N D A M E N T A L S_{t}\end{array}$ & $\begin{array}{c}\mathbf{0 . 0 0 3} * * * \\
(3.14)\end{array}$ & & \\
\hline$L E N G T H \_I N V_{t}$ & & $\begin{array}{c}0.027 * * \\
(1.97)\end{array}$ & \\
\hline $\begin{array}{l}\text { LENGTH_INV } \times \\
\text { FUNDAMENTALS }\end{array}$ & & $\begin{array}{l}0.003 \\
(1.32)\end{array}$ & \\
\hline$A I M R \_S C O R E_{t}$ & & & $\begin{array}{c}0.056^{* * *} \\
(3.85)\end{array}$ \\
\hline $\begin{array}{l}\text { AIMR_SCORE } \times \\
\text { FUNDAMENTALS }\end{array}$ & & & $\begin{array}{c}\mathbf{0 . 0 1 2} * * * \\
(\mathbf{5 . 0 0 )}\end{array}$ \\
\hline FUNDAMENTALS $S_{i}$ & $\begin{array}{c}0.052 * * * \\
(3.04)\end{array}$ & $\begin{array}{l}0.028 \\
(1.23)\end{array}$ & $\begin{array}{c}-0.005^{* *} \\
(-2.86)\end{array}$ \\
\hline $\operatorname{EQUITY}_{t+1}$ & $\begin{array}{c}-0.094 * * * \\
(-74.23)\end{array}$ & $\begin{array}{c}-0.094 * * * \\
(-74.17)\end{array}$ & $\begin{array}{c}-0.102 * * \\
(-82.15)\end{array}$ \\
\hline LOGASSETS $_{t}$ & $\begin{array}{l}0.000 \\
(0.05)\end{array}$ & $\begin{array}{l}0.000 \\
(0.12)\end{array}$ & $\begin{array}{c}0.014 * * \\
(3.90)\end{array}$ \\
\hline$M T B_{t}$ & $\begin{array}{c}0.002 * * * \\
(3.52)\end{array}$ & $\begin{array}{c}0.002 * * * \\
(3.62)\end{array}$ & $\begin{array}{c}0.005^{* * *} \\
(4.67)\end{array}$ \\
\hline$S \& P 500_{t}$ & $\begin{array}{l}0.016 * * * \\
(2.71)\end{array}$ & $\begin{array}{l}0.011^{*} \\
(1.81)\end{array}$ & $\begin{array}{c}0.022 * * \\
(3.95)\end{array}$ \\
\hline ANALYST $_{t}$ & $\begin{array}{c}0.023 * * * \\
(4.83)\end{array}$ & $\begin{array}{c}0.021 * * * \\
(4.39)\end{array}$ & $\begin{array}{l}0.002 \\
(0.72)\end{array}$ \\
\hline SHAREHOLDERS & $\begin{array}{l}-0.003 \\
(-1.08)\end{array}$ & $\begin{array}{l}-0.001 \\
(-0.29)\end{array}$ & $\begin{array}{l}-0.003 \\
(-1.11)\end{array}$ \\
\hline$R O A_{t}$ & $\begin{array}{l}0.026 \\
(0.70)\end{array}$ & $\begin{array}{l}0.027 \\
(0.72)\end{array}$ & $\begin{array}{c}-0.141 * * \\
(-3.73)\end{array}$ \\
\hline$F F_{-} B E T A_{t+1}$ & $\begin{array}{c}0.006^{* *} \\
(2.19)\end{array}$ & $\begin{array}{c}0.006 * * \\
(2.04)\end{array}$ & $\begin{array}{l}0.002 \\
(0.63)\end{array}$ \\
\hline$R E T_{-} V O L_{t}$ & $\begin{array}{l}-0.007 \\
(-0.10)\end{array}$ & $\begin{array}{l}-0.073 \\
(-1.18)\end{array}$ & $\begin{array}{l}0.085 \\
(1.60)\end{array}$ \\
\hline$E A R N_{-} V O L_{t}$ & $\begin{array}{l}-0.020 \\
(-0.38)\end{array}$ & $\begin{array}{l}-0.009 \\
(-0.17)\end{array}$ & $\begin{array}{l}-0.179^{*} \\
(-2.12)\end{array}$ \\
\hline$N B S E G_{t}$ & $\begin{array}{l}0.006 \\
(1.14)\end{array}$ & $\begin{array}{l}0.005 \\
(0.91)\end{array}$ & $\begin{array}{c}0.024 * * \\
(4.66)\end{array}$ \\
\hline$N G S E G_{t}$ & $\begin{array}{c}0.022 * * \\
(2.25)\end{array}$ & $\begin{array}{l}0.026 * * * \\
(2.72)\end{array}$ & $\begin{array}{l}0.030 * * \\
(2.93)\end{array}$ \\
\hline NITEMS $_{t}$ & $\begin{array}{l}-0.002 \\
(-0.09)\end{array}$ & $\begin{array}{l}-0.000 \\
(-0.01)\end{array}$ & $\begin{array}{c}0.083 * * \\
(3.42)\end{array}$ \\
\hline $\operatorname{LOSS}_{t}$ & $\begin{array}{c}-0.024 * * \\
(-2.35)\end{array}$ & $\begin{array}{c}-0.026^{* *} \\
(-2.46)\end{array}$ & $\begin{array}{c}-0.050 * * \\
(-8.08)\end{array}$ \\
\hline No. of Observations & 26,230 & 26,230 & 54,816 \\
\hline Adjusted $R^{2}$ & 0.32 & 0.32 & 0.32 \\
\hline
\end{tabular}

This table presents an analysis of the relation between individuals' use of financial disclosure and the firm's financial strength for the following three financial disclosure measures: annual report readability $\left(F O G \_I N V\right)$, annual report length $\left(L E N G T H \_I N V\right)$, and analysts' disclosure scores (AIMR_SCORE). *, **, 
*** indicate significance at the $0.10,0.05$, and 0.01 levels, respectively, using two-tailed tests. $T$-statistics and $p$-values are calculated using clustered standard errors by individual investor account number. See Appendix A for variable definitions. 
TABLE 10

Changes in Financial Disclosure and Changes in Next-Year's Individual Investors' Shareholdings

\begin{tabular}{|c|c|c|c|}
\hline & \multicolumn{3}{|c|}{ Dependent Variable $=\Delta H O L D I N G S_{t+1}$} \\
\hline & I. & II. & III. \\
\hline$\Delta F O G_{-} I N V_{t}$ & $\begin{array}{c}0.004 * * \\
(2.31)\end{array}$ & & \\
\hline$\triangle L E N G T H_{-} I N V_{t}$ & & $\begin{array}{c}0.015 * * * \\
(5.62)\end{array}$ & \\
\hline AAIMR_SCORE $E_{t}$ & & & $\begin{array}{c}\mathbf{0 . 0 0 4} * * \\
(2.07)\end{array}$ \\
\hline$\triangle E Q U I T Y_{t+1}$ & $\begin{array}{c}-0.035 * * * \\
(-16.64)\end{array}$ & $\begin{array}{c}-0.035 * * * \\
(-16.75)\end{array}$ & $\begin{array}{c}-0.049 * * * \\
(-51.29)\end{array}$ \\
\hline$\triangle L O G A S S E T S_{t}$ & $\begin{array}{c}0.039 * * * \\
(2.77)\end{array}$ & $\begin{array}{c}0.035^{* *} \\
(2.53)\end{array}$ & $\begin{array}{c}0.019 * * * \\
(6.39)\end{array}$ \\
\hline$\triangle M T B_{t}$ & $\begin{array}{c}0.000^{*} \\
(1.85)\end{array}$ & $\begin{array}{c}0.000 * * \\
(2.21)\end{array}$ & $\begin{array}{c}-0.000 * * * \\
(-3.00)\end{array}$ \\
\hline$\triangle A N A L Y S T_{t}$ & $\begin{array}{l}0.003 \\
(0.24)\end{array}$ & $\begin{array}{l}-0.004 \\
(-0.34)\end{array}$ & $\begin{array}{c}-0.023 * * * \\
(-6.02)\end{array}$ \\
\hline$\triangle S H A R E H O L D E R S_{t}$ & $\begin{array}{c}0.030 * * * \\
(5.36)\end{array}$ & $\begin{array}{c}0.027 * * * \\
(4.92)\end{array}$ & $\begin{array}{c}0.029 * * * \\
(11.67)\end{array}$ \\
\hline$\triangle R O A_{t}$ & $\begin{array}{l}0.074^{*} \\
(1.72)\end{array}$ & $\begin{array}{c}0.111 * * \\
(2.55)\end{array}$ & $\begin{array}{c}-0.023^{* *} \\
(-2.19)\end{array}$ \\
\hline$\triangle F F_{-} B E T A_{t+1}$ & $\begin{array}{c}-0.004 * \\
(-1.78)\end{array}$ & $\begin{array}{c}-0.005 * * \\
(-2.18)\end{array}$ & $\begin{array}{c}-0.005 * * * \\
(-5.60)\end{array}$ \\
\hline$\triangle R E T_{-} V O L_{t}$ & $\begin{array}{l}0.094 \\
(1.42)\end{array}$ & $\begin{array}{l}-0.013 \\
(-0.20)\end{array}$ & $\begin{array}{c}0.040 * * * \\
(3.27)\end{array}$ \\
\hline$\triangle E A R N_{-} V O L_{t}$ & $\begin{array}{c}-0.286^{* * *} \\
(-3.34)\end{array}$ & $\begin{array}{c}-0.156^{*} \\
(-1.77)\end{array}$ & $\begin{array}{l}-0.023 \\
(-0.69)\end{array}$ \\
\hline$\triangle N B S E G_{t}$ & $\begin{array}{l}-0.003 \\
(-0.12)\end{array}$ & $\begin{array}{l}0.003 \\
(0.12)\end{array}$ & $\begin{array}{l}0.004 \\
(1.38)\end{array}$ \\
\hline$\triangle N G S E G_{t}$ & $\begin{array}{c}-0.058 * * * \\
(-3.79)\end{array}$ & $\begin{array}{c}-0.040 * * \\
(-2.57)\end{array}$ & $\begin{array}{l}0.013 * \\
(1.94)\end{array}$ \\
\hline$\triangle N I T E M S_{t}$ & $\begin{array}{c}0.050 * * * \\
(2.80)\end{array}$ & $\begin{array}{c}0.094 * * * \\
(5.00)\end{array}$ & $\begin{array}{c}0.020 * * * \\
(3.63)\end{array}$ \\
\hline$\triangle L O S S_{t}$ & $\begin{array}{l}0.007 \\
(0.86)\end{array}$ & $\begin{array}{l}0.015^{*} \\
(1.96)\end{array}$ & $\begin{array}{l}-0.001 \\
(-1.22)\end{array}$ \\
\hline No. of Observations & 8,753 & 8,753 & 117,695 \\
\hline Adjusted $R^{2}$ & 0.06 & 0.06 & 0.06 \\
\hline
\end{tabular}

This table presents an analysis of the relation between changes in financial disclosure and changes in nextyear's individual investors' shareholdings using the following three financial disclosure measures: annual report readability (FOG_INV), annual report length ( $\left.L E N G T H \_I N V\right)$, and analysts' disclosure scores $\left(A I M R \_S C O R E\right) . *{ }^{*} * * * *$ indicate significance at the $0.10,0.05$, and 0.01 levels, respectively, using twotailed tests. $T$-statistics and $p$-values are calculated using clustered standard errors by individual investor account number. See Appendix A for variable definitions. 


\section{TABLE 11}

Individual Investors' Shareholdings and Financial Disclosure: Additional Individual Controls

\begin{tabular}{|c|c|c|c|}
\hline & \multicolumn{3}{|c|}{ Dependent Variable $=H O L D I N G S_{t+1}$} \\
\hline & I. & II. & III. \\
\hline$F O G \_I N V_{t}$ & $\begin{array}{c}0.004 * * * \\
(4.05)\end{array}$ & & \\
\hline$L E N G T H \_I N V_{t}$ & & $\begin{array}{c}0.009 * * * \\
(4.78)\end{array}$ & \\
\hline$A I M R \_S C O R E_{t}$ & & & $\begin{array}{c}0.019 * * * \\
(5.29)\end{array}$ \\
\hline STOCKS_HELD & $\begin{array}{c}-0.003 * * * \\
(-3.57)\end{array}$ & $\begin{array}{c}-0.003 * * * \\
(-3.57)\end{array}$ & $\begin{array}{c}-0.003 * * * \\
(-2.92)\end{array}$ \\
\hline INVEST_EXP & $\begin{array}{c}-0.037 * * * \\
(-9.81)\end{array}$ & $\begin{array}{c}-0.037 * * * \\
(-9.80)\end{array}$ & $\begin{array}{c}-0.038 * * * \\
(-11.69)\end{array}$ \\
\hline$A G E$ & $\begin{array}{l}-0.000 \\
(-0.16)\end{array}$ & $\begin{array}{l}-0.000 \\
(-0.16)\end{array}$ & $\begin{array}{l}0.001 \\
(0.80)\end{array}$ \\
\hline FEMALE & $\begin{array}{l}0.002 \\
(0.26)\end{array}$ & $\begin{array}{l}0.002 \\
(0.25)\end{array}$ & $\begin{array}{c}0.017 * * * \\
(3.39)\end{array}$ \\
\hline$E Q U I T Y_{t+1}$ & $\begin{array}{c}-0.085^{* * *} * \\
(-29.11)\end{array}$ & $\begin{array}{c}-0.085^{* * *} * \\
(-29.13)\end{array}$ & $\begin{array}{c}-0.093 * * * \\
(-28.13)\end{array}$ \\
\hline LOGASSETS $_{t}$ & $\begin{array}{c}0.016^{* * * *} \\
(8.09)\end{array}$ & $\begin{array}{c}0.017 * * * \\
(8.49)\end{array}$ & $\begin{array}{c}0.013 * * * \\
(5.93)\end{array}$ \\
\hline$M T B_{t}$ & $\begin{array}{c}0.001 * * * \\
(5.70)\end{array}$ & $\begin{array}{c}0.001 * * * \\
(5.84)\end{array}$ & $\begin{array}{c}-0.000 * * \\
(-1.99)\end{array}$ \\
\hline$S \& P 500_{t}$ & $\begin{array}{c}0.015^{* * * *} \\
(3.78)\end{array}$ & $\begin{array}{c}0.013 * * * \\
(3.33)\end{array}$ & $\begin{array}{c}0.038 * * * \\
(11.75)\end{array}$ \\
\hline$A N A L Y S T_{t}$ & $\begin{array}{l}-0.000 \\
(-0.17)\end{array}$ & $\begin{array}{l}-0.001 \\
(-0.24)\end{array}$ & $\begin{array}{c}0.012 * * * \\
(5.70)\end{array}$ \\
\hline SHAREHOLDERS $_{t}$ & $\begin{array}{l}-0.001 \\
(-0.64)\end{array}$ & $\begin{array}{l}-0.000 \\
(-0.21)\end{array}$ & $\begin{array}{l}0.001 \\
(0.30)\end{array}$ \\
\hline$R O A_{t}$ & $\begin{array}{c}0.077 * * * \\
(4.56)\end{array}$ & $\begin{array}{c}0.078 * * * \\
(4.62)\end{array}$ & $\begin{array}{c}0.094 * * * \\
(4.17)\end{array}$ \\
\hline$F F_{-} B E T A_{t+1}$ & $\begin{array}{c}-0.007 * * * \\
(-3.20)\end{array}$ & $\begin{array}{c}-0.006^{* * *} \\
(-3.00)\end{array}$ & $\begin{array}{c}-0.030 * * * \\
(-14.26)\end{array}$ \\
\hline$R E T_{-} V O L_{t}$ & $\begin{array}{c}-0.291 * * * \\
(-6.82)\end{array}$ & $\begin{array}{c}-0.302 * * * \\
(-7.08)\end{array}$ & $\begin{array}{c}-0.103 * * * \\
(-2.93)\end{array}$ \\
\hline$E A R N_{-} V O L_{t}$ & $\begin{array}{l}0.048^{*} \\
(1.73)\end{array}$ & $\begin{array}{c}0.070 * * \\
(2.54)\end{array}$ & $\begin{array}{c}0.111 * * \\
(2.16)\end{array}$ \\
\hline$N B S E G_{t}$ & $\begin{array}{l}0.003 \\
(0.91)\end{array}$ & $\begin{array}{l}0.004 \\
(1.01)\end{array}$ & $\begin{array}{c}-0.019 * * * \\
(-6.61)\end{array}$ \\
\hline$N G S E G_{t}$ & $\begin{array}{c}0.014 * * \\
(2.07)\end{array}$ & $\begin{array}{l}0.013 * \\
(1.91)\end{array}$ & $\begin{array}{c}0.013 \\
(1.62)\end{array}$ \\
\hline$N_{I T E M S}$ & $\begin{array}{c}0.076 * * * \\
(5.64)\end{array}$ & $\begin{array}{c}0.080 * * * \\
(6.01)\end{array}$ & $\begin{array}{l}-0.008 \\
(-0.61)\end{array}$ \\
\hline $\operatorname{LOSS}_{t}$ & $\begin{array}{l}-0.006 \\
(-0.90)\end{array}$ & $\begin{array}{l}-0.006 \\
(-0.94)\end{array}$ & $\begin{array}{c}-0.022 * * * \\
(-7.29)\end{array}$ \\
\hline No. of Observations & 50,900 & 50,900 & 137,170 \\
\hline Adjusted $R^{2}$ & 0.32 & 0.32 & 0.31 \\
\hline
\end{tabular}


This table presents an analysis of the relation between individual investors' shareholdings (HOLDINGS) and the following three financial disclosure measures: annual report readability $\left(F O G_{-} I N V\right)$, annual report length $\left(L E N G T H \_I N V\right)$, and analysts' disclosure scores (AIMR_SCORE); controlling for the following additional individual attributes: STOCKS_HELD, INVEST_EXP, AGE, and FEMALE.*, **,*** indicate significance at the $0.10,0.05$, and 0.01 levels, respectively, using two-tailed tests. $T$-statistics and $p$-values are calculated using clustered standard errors by individual investor account number. All regressions include year and industry fixed-effects; however, for brevity, these separate intercepts are not reported. See Appendix A for variable definitions. 


\section{TABLE 12}

Individual Investors' Shareholdings and Financial Disclosure: Additional Firm-Level Controls

\begin{tabular}{|c|c|c|c|}
\hline & \multicolumn{3}{|c|}{ Dependent Variable $=H O L D I N G S_{t+1}$} \\
\hline & I. & II. & III. \\
\hline$F O G \_I N V_{t}$ & $\begin{array}{c}\mathbf{0 . 0 0 4} * * * \\
(5.76)\end{array}$ & & \\
\hline$L E N G T H \_I N V_{t}$ & & $\begin{array}{c}\mathbf{0 . 0 0 7} * * * \\
(\mathbf{5 . 1 8})\end{array}$ & \\
\hline$A I M R \_S C O R E_{t}$ & & & $\begin{array}{c}0.024 * * * \\
(9.01)\end{array}$ \\
\hline FIRM_AGE & $\begin{array}{c}0.010 * * * \\
(5.27)\end{array}$ & $\begin{array}{c}0.009 * * * \\
(4.68)\end{array}$ & $\begin{array}{l}-0.002 \\
(-0.81)\end{array}$ \\
\hline$S I$ & $\begin{array}{c}0.150 * * * \\
(5.42)\end{array}$ & $\begin{array}{c}0.134 * * * \\
(4.86)\end{array}$ & $\begin{array}{c}-0.064 * * \\
(-2.35)\end{array}$ \\
\hline$F F \_S M B$ & $\begin{array}{c}-0.011 * * * \\
(-4.55)\end{array}$ & $\begin{array}{c}-0.010 * * * \\
(-4.41)\end{array}$ & $\begin{array}{c}-0.013 * * * \\
(-8.66)\end{array}$ \\
\hline$F F_{-} H M L$ & $\begin{array}{c}0.003^{* *} \\
(2.25)\end{array}$ & $\begin{array}{c}0.003^{* * *} \\
(2.39)\end{array}$ & $\begin{array}{c}0.003 * * \\
(2.16)\end{array}$ \\
\hline CARHART_MOMENTUM & $\begin{array}{c}0.016 * * * \\
(13.03)\end{array}$ & $\begin{array}{c}0.017 * * * \\
(13.36)\end{array}$ & $\begin{array}{c}0.019 * * * \\
(22.08)\end{array}$ \\
\hline$E_{Q U I T Y}{ }_{t+1}$ & $\begin{array}{c}-0.097 * * * \\
(-107.46)\end{array}$ & $\begin{array}{c}-0.097 * * * \\
(-107.38)\end{array}$ & $\begin{array}{c}-0.105 * * * \\
(-130.04)\end{array}$ \\
\hline LOGASSETS $_{t}$ & $\begin{array}{c}0.014 * * * \\
(9.13)\end{array}$ & $\begin{array}{c}0.015^{* * *} \\
(9.76)\end{array}$ & $\begin{array}{c}0.009 * * * \\
(5.40)\end{array}$ \\
\hline$M T B_{t}$ & $\begin{array}{c}0.001 * * * \\
(6.74)\end{array}$ & $\begin{array}{c}0.001 * * * \\
(6.93)\end{array}$ & $\begin{array}{c}-0.000 * * \\
(-2.13)\end{array}$ \\
\hline$S \& P 500_{t}$ & $\begin{array}{c}0.009 * * * \\
(2.96)\end{array}$ & $\begin{array}{c}0.007 * * \\
(2.50)\end{array}$ & $\begin{array}{c}0.032 * * * \\
(13.28)\end{array}$ \\
\hline ANALYST $_{t}$ & $\begin{array}{c}0.005^{* *} \\
(2.35)\end{array}$ & $\begin{array}{c}0.004^{* *} \\
(1.99)\end{array}$ & $\begin{array}{c}0.015^{* * * *} \\
(9.47)\end{array}$ \\
\hline SHAREHOLDERS $S_{t}$ & $\begin{array}{c}-0.003 * * \\
(-2.52)\end{array}$ & $\begin{array}{l}-0.002 * \\
(-1.81)\end{array}$ & $\begin{array}{c}0.005^{* * * *} \\
(3.57)\end{array}$ \\
\hline$R O A_{t}$ & $\begin{array}{l}0.012 \\
(0.89)\end{array}$ & $\begin{array}{l}0.017 \\
(1.25)\end{array}$ & $\begin{array}{c}0.087 * * * \\
(4.38)\end{array}$ \\
\hline$F F_{-} B E T A_{t+1}$ & $\begin{array}{c}-0.005^{* *} \\
(-2.06)\end{array}$ & $\begin{array}{c}-0.005^{* *} \\
(-2.07)\end{array}$ & $\begin{array}{c}-0.010 * * * \\
(-5.63)\end{array}$ \\
\hline$R E T_{-} V O L_{t}$ & $\begin{array}{c}-0.200 * * * \\
(-6.34)\end{array}$ & $\begin{array}{c}-0.212 * * * \\
(-6.70)\end{array}$ & $\begin{array}{c}-0.180 * * * \\
(-7.05)\end{array}$ \\
\hline$E A R N_{-} V O L_{t}$ & $\begin{array}{c}0.091 * * * \\
(3.85)\end{array}$ & $\begin{array}{c}0.108 * * * \\
(4.58)\end{array}$ & $\begin{array}{c}0.125^{* * * *} \\
(3.12)\end{array}$ \\
\hline$N B S E G_{t}$ & $\begin{array}{l}0.003 \\
(1.04)\end{array}$ & $\begin{array}{l}0.003 \\
(1.06)\end{array}$ & $\begin{array}{c}-0.023 * * * \\
(-10.22)\end{array}$ \\
\hline$N G S E G_{t}$ & $\begin{array}{c}0.013 * * \\
(2.55)\end{array}$ & $\begin{array}{l}0.011 * * \\
(2.29)\end{array}$ & $\begin{array}{c}0.018 * * * \\
(3.12)\end{array}$ \\
\hline NITEMS $_{t}$ & $\begin{array}{c}0.077 * * * \\
(7.80)\end{array}$ & $\begin{array}{c}0.080 * * * \\
(8.04)\end{array}$ & $\begin{array}{l}0.010 \\
(1.14)\end{array}$ \\
\hline $\operatorname{LOSS}_{t}$ & $\begin{array}{l}-0.007 \\
(-1.47)\end{array}$ & $\begin{array}{l}-0.008 \\
(-1.62)\end{array}$ & $\begin{array}{c}-0.015^{* * * *} \\
(-6.58)\end{array}$ \\
\hline No. of Observations & 91,228 & 91,228 & 249,888 \\
\hline Adjusted $R^{2}$ & 0.32 & 0.32 & 0.31 \\
\hline
\end{tabular}


This table presents an analysis of the relation between individual investors' shareholdings $\left(L O G \_H O L D I N G S\right)$ and the following three financial disclosure measures: annual report readability $\left(F O G_{-} I N V\right)$, annual report length (LENGTH_INV), and analysts' disclosure scores (AIMR_SCORE); controlling for the following additional firm-level attributes: FIRM_AGE, SI, FF_SMB, FF_HML, and CARHART_MOMENTUM. *,**,*** indicate significance at the $0.10,0.05$, and 0.01 levels, respectively, using two-tailed tests. $T$-statistics and $p$-values are calculated using clustered standard errors by individual investor account number. All regressions include year and industry fixed-effects; however, for brevity, these separate intercepts are not reported. See Appendix A for variable definitions. 
TABLE 13

Individual Investors' Shareholdings and Financial Disclosure: Controlling for Earnings Quality

\begin{tabular}{|c|c|c|c|}
\hline & \multicolumn{3}{|c|}{ Dependent Variable $=H O L D I N G S_{t+1}$} \\
\hline & I. & II. & III. \\
\hline$F O G_{-} I N V_{t}$ & $\begin{array}{c}0.005 * * * \\
(6.03)\end{array}$ & & \\
\hline LENGTH_INV & & $\begin{array}{c}0.008 * * * \\
(5.33)\end{array}$ & \\
\hline$A I M R \_S C O R E_{t}$ & & & $\begin{array}{c}0.008 * * * \\
(2.78)\end{array}$ \\
\hline$E Q U I T Y_{t+1}$ & $\begin{array}{c}-0.097 * * * \\
(-100.28)\end{array}$ & $\begin{array}{c}-0.097 * * * \\
(-100.17)\end{array}$ & $\begin{array}{c}-0.105 * * * \\
(-125.55)\end{array}$ \\
\hline LOGASSETS $_{t}$ & $\begin{array}{c}0.020 * * * \\
(11.34)\end{array}$ & $\begin{array}{c}0.021 * * * \\
(11.59)\end{array}$ & $\begin{array}{c}0.012 * * * \\
(6.38)\end{array}$ \\
\hline$M T B_{t}$ & $\begin{array}{c}0.001 * * * \\
(5.11)\end{array}$ & $\begin{array}{c}0.002 * * * \\
(5.53)\end{array}$ & $\begin{array}{c}-0.000 * * * \\
(-3.34)\end{array}$ \\
\hline$S \& P 500_{t}$ & $\begin{array}{c}0.007^{* *} \\
(2.19)\end{array}$ & $\begin{array}{l}0.005 \\
(1.57)\end{array}$ & $\begin{array}{c}0.038^{* * * *} \\
(13.34)\end{array}$ \\
\hline$A N A L Y S T_{t}$ & $\begin{array}{c}-0.005^{* *} \\
(-2.00)\end{array}$ & $\begin{array}{c}-0.005^{* *} \\
(-1.98)\end{array}$ & $\begin{array}{c}0.010 * * * \\
(5.88)\end{array}$ \\
\hline SHAREHOLDERS $_{t}$ & $\begin{array}{l}-0.000 \\
(-0.25)\end{array}$ & $\begin{array}{l}0.000 \\
(0.38)\end{array}$ & $\begin{array}{l}-0.000 \\
(-0.18)\end{array}$ \\
\hline$R O A_{t}$ & $\begin{array}{c}0.029 * * \\
(2.27)\end{array}$ & $\begin{array}{c}0.029 * * \\
(2.24)\end{array}$ & $\begin{array}{c}0.106 * * * \\
(6.09)\end{array}$ \\
\hline$F F_{-} B E T A_{t+1}$ & $\begin{array}{l}0.000 \\
(0.22)\end{array}$ & $\begin{array}{l}-0.000 \\
(-0.02)\end{array}$ & $\begin{array}{c}-0.018 * * * * \\
(-10.87)\end{array}$ \\
\hline$R E T_{-} V O L_{t}$ & $\begin{array}{c}-0.105^{* * * *} \\
(-3.04)\end{array}$ & $\begin{array}{c}-0.118 * * * \\
(-3.42)\end{array}$ & $\begin{array}{c}-0.129 * * * \\
(-4.45)\end{array}$ \\
\hline$E A R N_{-} V O L_{t}$ & $\begin{array}{c}0.062 * * \\
(2.55)\end{array}$ & $\begin{array}{c}0.080 * * * \\
(3.27)\end{array}$ & $\begin{array}{c}-0.101 * * \\
(-2.54)\end{array}$ \\
\hline$N B S E G_{t}$ & $\begin{array}{l}0.004 \\
(1.39)\end{array}$ & $\begin{array}{l}0.003 \\
(1.21)\end{array}$ & $\begin{array}{l}-0.003 \\
(-1.10)\end{array}$ \\
\hline$N G S E G_{t}$ & $\begin{array}{c}0.012 * * \\
(2.24)\end{array}$ & $\begin{array}{l}0.008 \\
(1.58)\end{array}$ & $\begin{array}{c}0.018^{* * * *} \\
(2.70)\end{array}$ \\
\hline NITEMS $_{t}$ & $\begin{array}{c}0.040 * * * \\
(3.61)\end{array}$ & $\begin{array}{c}0.038 * * * \\
(3.42)\end{array}$ & $\begin{array}{l}-0.005 \\
(-0.47)\end{array}$ \\
\hline $\operatorname{LOSS}_{t}$ & $\begin{array}{c}-0.019 * * * \\
(-3.64)\end{array}$ & $\begin{array}{c}-0.022 * * * \\
(-4.18)\end{array}$ & $\begin{array}{c}-0.015 * * * \\
(-5.69)\end{array}$ \\
\hline$D A_{t}$ & $\begin{array}{c}-0.020 * \\
(-1.74)\end{array}$ & $\begin{array}{l}-0.016 \\
(-1.38)\end{array}$ & $\begin{array}{c}-0.032 * * * * \\
(-3.24)\end{array}$ \\
\hline No. of Observations & 75,005 & 75,005 & 216,354 \\
\hline Adjusted $R^{2}$ & 0.32 & 0.32 & 0.32 \\
\hline
\end{tabular}

This table presents an analysis of the relation between individual investors' shareholdings and the following three financial disclosure measures: annual report readability $\left(F O G \_I N V\right)$, annual report length $\left(L E N G T H_{-} I N V\right)$, and analysts' disclosure scores (AIMR_SCORE), controlling for discretionary accruals $(D A) . * * *, * * *$ indicate significance at the $0.10,0.05$, and 0.01 levels, respectively, using two-tailed tests. $T$ statistics and $p$-values are calculated using clustered standard errors by individual investor account number. 
All regressions include year and industry fixed-effects; however, for brevity, these separate intercepts are not reported. See Appendix A for variable definitions. 


\section{TABLE 14}

Individual Investors' Shareholdings and Financial Disclosure: Firm-Level Clustering

\begin{tabular}{|c|c|c|c|}
\hline & \multicolumn{3}{|c|}{ Dependent Variable $=H O L D I N G S_{t+1}$} \\
\hline & I. & II. & III. \\
\hline$F O G_{-} I N V_{t}$ & $\begin{array}{c}0.005 * * \\
(2.05)\end{array}$ & & \\
\hline LENGTH_INV $V_{t}$ & & $\begin{array}{c}\text { 0.008* } \\
(1.72)\end{array}$ & \\
\hline$A I M R \_S C O R E_{t}$ & & & $\begin{array}{c}0.022 * * \\
(2.29)\end{array}$ \\
\hline$E Q U I T Y_{t+1}$ & $\begin{array}{c}-0.097 * * * \\
(-56.16)\end{array}$ & $\begin{array}{c}-0.097 * * * \\
(-56.29)\end{array}$ & $\begin{array}{r}-0.105^{* * *} \\
(-53.52)\end{array}$ \\
\hline LOGASSETS $_{t}$ & $\begin{array}{c}0.017 * * * \\
(3.43)\end{array}$ & $\begin{array}{c}0.018 * * * \\
(3.51)\end{array}$ & $\begin{array}{c}0.011 * * \\
(2.14)\end{array}$ \\
\hline$M T B_{t}$ & $\begin{array}{c}0.001 * * * \\
(2.60)\end{array}$ & $\begin{array}{c}0.001 * * \\
(2.56)\end{array}$ & $\begin{array}{l}-0.000 \\
(-1.19)\end{array}$ \\
\hline$S \& P 50 O_{t}$ & $\begin{array}{l}0.009 \\
(0.92)\end{array}$ & $\begin{array}{l}0.008 \\
(0.79)\end{array}$ & $\begin{array}{c}0.035^{* * *} * \\
(3.26)\end{array}$ \\
\hline ANALYST $_{t}$ & $\begin{array}{l}0.001 \\
(0.13)\end{array}$ & $\begin{array}{l}0.000 \\
(0.06)\end{array}$ & $\begin{array}{c}0.013 * * * \\
(3.12)\end{array}$ \\
\hline SHAREHOLDERS $_{t}$ & $\begin{array}{l}-0.000 \\
(-0.12)\end{array}$ & $\begin{array}{l}0.000 \\
(0.09)\end{array}$ & $\begin{array}{l}0.003 \\
(0.71)\end{array}$ \\
\hline$R O A_{t}$ & $\begin{array}{c}0.062 * \\
(1.70)\end{array}$ & $\begin{array}{c}0.064 * \\
(1.68)\end{array}$ & $\begin{array}{l}0.099 \\
(1.57)\end{array}$ \\
\hline$F F_{-} B E T A_{t+1}$ & $\begin{array}{l}-0.006 \\
(-1.13)\end{array}$ & $\begin{array}{l}-0.006 \\
(-1.03)\end{array}$ & $\begin{array}{c}-0.030 * * * \\
(-4.32)\end{array}$ \\
\hline$R E T_{-} V O L_{t}$ & $\begin{array}{c}-0.266 * * * \\
(-2.97)\end{array}$ & $\begin{array}{c}-0.280 * * * \\
(-2.84)\end{array}$ & $\begin{array}{l}-0.082 \\
(-0.93)\end{array}$ \\
\hline$E A R N_{-} V O L_{t}$ & $\begin{array}{c}0.096 * * \\
(2.14)\end{array}$ & $\begin{array}{c}0.117 * * \\
(2.50)\end{array}$ & $\begin{array}{l}0.094 \\
(0.73)\end{array}$ \\
\hline$N B S E G_{t}$ & $\begin{array}{l}0.001 \\
(0.09)\end{array}$ & $\begin{array}{l}0.000 \\
(0.04)\end{array}$ & $\begin{array}{c}-0.022 * * \\
(-2.03)\end{array}$ \\
\hline$N G S E G_{t}$ & $\begin{array}{l}0.019 \\
(1.09)\end{array}$ & $\begin{array}{c}0.018 \\
(1.04)\end{array}$ & $\begin{array}{c}0.016 \\
(0.92)\end{array}$ \\
\hline NITEMS $_{t}$ & $\begin{array}{c}0.074 * * \\
(2.43)\end{array}$ & $\begin{array}{c}0.078^{* *} \\
(2.52)\end{array}$ & $\begin{array}{l}0.003 \\
(0.10)\end{array}$ \\
\hline $\operatorname{LOSS}_{t}$ & $\begin{array}{l}-0.009 \\
(-0.77)\end{array}$ & $\begin{array}{l}-0.010 \\
(-0.82)\end{array}$ & $\begin{array}{c}-0.019 * * \\
(-2.01)\end{array}$ \\
\hline No. of Observations & 91,228 & 91,228 & 249,888 \\
\hline Adjusted $R^{2}$ & 0.32 & 0.32 & 0.31 \\
\hline
\end{tabular}

This table presents an analysis of the relation between individual investors' shareholdings (HOLDINGS) and the following three financial disclosure measures: annual report readability (FOG_INV), annual report length $($ LENGTH_INV), and analysts' disclosure scores (AIMR_SCORE). *, **, *** indicate significance at the $0.10,0.05$, and 0.01 levels, respectively, using two-tailed tests. $T$-statistics and $p$-values are calculated using clustered standard errors by firm. All regressions include year and industry fixed-effects; however, for brevity, these separate intercepts are not reported. See Appendix A for variable definitions. 
TABLE 15

Individual Investors' Shareholdings and Financial Disclosure: Alternative Holdings

Measure

\begin{tabular}{|c|c|c|c|}
\hline & \multicolumn{3}{|c|}{ Dependent Variable $=L O G \_H O L D I N G S_{t+1}$} \\
\hline & I. & II. & III. \\
\hline$F O G_{-} I N V_{t}$ & $\begin{array}{c}0.026 * * * \\
(6.11)\end{array}$ & & \\
\hline$L E N G T H \_I N V_{t}$ & & $\begin{array}{c}0.056 * * * \\
(6.71)\end{array}$ & \\
\hline$A I M R \_S C O R E_{t}$ & & & $\begin{array}{c}\mathbf{0 . 0 8 3} * * * \\
(6.12)\end{array}$ \\
\hline$E Q U I T Y_{t+1}$ & $\begin{array}{c}0.449 * * * \\
(84.93)\end{array}$ & $\begin{array}{c}0.449 * * * \\
(84.94)\end{array}$ & $\begin{array}{c}0.467 * * * \\
(69.31)\end{array}$ \\
\hline LOGASSETS $_{t}$ & $\begin{array}{c}0.104 * * * \\
(11.39)\end{array}$ & $\begin{array}{c}0.109 * * * \\
(11.93)\end{array}$ & $\begin{array}{c}0.080^{* * *} \\
(9.65)\end{array}$ \\
\hline$M T B_{t}$ & $\begin{array}{c}0.005^{* * *} * \\
(7.90)\end{array}$ & $\begin{array}{c}0.005 * * * \\
(8.12)\end{array}$ & $\begin{array}{c}-0.002 * * * \\
(-8.33)\end{array}$ \\
\hline$S \& P 500_{t}$ & $\begin{array}{c}0.078 * * * \\
(4.66)\end{array}$ & $\begin{array}{c}0.068 * * * \\
(4.05)\end{array}$ & $\begin{array}{c}0.196 * * * \\
(16.19)\end{array}$ \\
\hline$A N A L Y S T_{t}$ & $\begin{array}{c}0.060 * * * \\
(4.84)\end{array}$ & $\begin{array}{c}0.058 * * * \\
(4.75)\end{array}$ & $\begin{array}{c}0.075 * * * \\
(8.87)\end{array}$ \\
\hline SHAREHOLDERS $_{t}$ & $\begin{array}{l}0.004 \\
(0.50)\end{array}$ & $\begin{array}{l}0.008 \\
(1.15)\end{array}$ & $\begin{array}{c}0.025 * * * \\
(3.68)\end{array}$ \\
\hline$R O A_{t}$ & $\begin{array}{c}0.557 * * * \\
(6.98)\end{array}$ & $\begin{array}{c}0.567 * * * \\
(7.08)\end{array}$ & $\begin{array}{c}0.830 * * * \\
(9.09)\end{array}$ \\
\hline$F F_{-} B E T A_{t+1}$ & $\begin{array}{c}-0.056 * * * \\
(-5.54)\end{array}$ & $\begin{array}{c}-0.053 * * * \\
(-5.25)\end{array}$ & $\begin{array}{c}-0.198 * * * \\
(-20.03)\end{array}$ \\
\hline$R E T_{-} V O L_{t}$ & $\begin{array}{c}-1.993 * * * \\
(-10.68)\end{array}$ & $\begin{array}{c}-2.067 * * * \\
(-11.09)\end{array}$ & $\begin{array}{c}-0.465 * * * \\
(-3.02)\end{array}$ \\
\hline$E A R N_{-} V O L_{t}$ & $\begin{array}{c}0.686^{* * *} * \\
(5.27)\end{array}$ & $\begin{array}{c}0.825 * * * \\
(6.30)\end{array}$ & $\begin{array}{l}0.279 \\
(1.32)\end{array}$ \\
\hline$N B S E G_{t}$ & $\begin{array}{c}0.031 * * \\
(2.07)\end{array}$ & $\begin{array}{c}0.031 * * \\
(2.13)\end{array}$ & $\begin{array}{c}-0.074 * * * \\
(-7.08)\end{array}$ \\
\hline$N G S E G_{t}$ & $\begin{array}{c}0.147 * * * \\
(5.03)\end{array}$ & $\begin{array}{c}0.140 * * * \\
(4.81)\end{array}$ & $\begin{array}{c}0.182 * * * \\
(6.20)\end{array}$ \\
\hline$N_{I T E M S}$ & $\begin{array}{c}0.334 * * * \\
(5.77)\end{array}$ & $\begin{array}{c}0.360 * * * \\
(6.21)\end{array}$ & $\begin{array}{l}0.042 \\
(0.94)\end{array}$ \\
\hline $\operatorname{LOSS}_{t}$ & $\begin{array}{c}-0.144 * * * * \\
(-4.66)\end{array}$ & $\begin{array}{c}-0.147 * * * \\
(-4.75)\end{array}$ & $\begin{array}{c}-0.122^{* * * *} \\
(-9.53)\end{array}$ \\
\hline No. of Observations & 91,228 & 91,228 & 249,888 \\
\hline Adjusted $R^{2}$ & 0.29 & 0.29 & 0.25 \\
\hline
\end{tabular}

This table presents an analysis of the relation between individual investors' shareholdings (LOG_HOLDINGS) and the following three financial disclosure measures: annual report readability $\left(F O G_{-} I N V\right)$, annual report length $\left(L E N G T H_{-} I N V\right)$, and analysts' disclosure scores $\left(A I M R \_S C O R E\right)$. *, **, *** indicate significance at the $0.10,0.05$, and 0.01 levels, respectively, using two-tailed tests. $T$-statistics and $p$-values are calculated using clustered standard errors by individual investor account number. All regressions include year and industry fixed-effects; however, for brevity, these separate intercepts are not reported. See Appendix A for variable definitions. 
TABLE 16

Individual Investors' Overconfidence and Financial Disclosure: Alternative Overconfidence Measures

\begin{tabular}{|c|c|c|c|c|c|c|}
\hline & \multicolumn{6}{|c|}{ Dependent Variable $=H O L D I N G S_{t+1}$} \\
\hline & \multicolumn{3}{|c|}{ OVERCON=BR_OVERCON } & \multicolumn{3}{|c|}{ OVERCON=AB_OVERCON } \\
\hline & I. & II. & III. & IV. & $\mathrm{V}$. & VI. \\
\hline$F O G_{-} I N V_{t}$ & $\begin{array}{c}0.006^{* * * *} \\
(6.69)\end{array}$ & & & $\begin{array}{c}0.005^{* * * *} \\
(7.66)\end{array}$ & & \\
\hline $\begin{array}{l}\text { FOG_INV } \times \\
\text { OVERCON }\end{array}$ & $\begin{array}{c}-0.005 * * * \\
(-4.46)\end{array}$ & & & $\begin{array}{c}-0.003 * * * \\
(-6.32)\end{array}$ & & \\
\hline$L E N G T H \_I N V_{t}$ & & $\begin{array}{c}0.012 * * * \\
(6.32)\end{array}$ & & & $\begin{array}{c}0.010 * * * \\
(7.27)\end{array}$ & \\
\hline $\begin{array}{l}\text { LENGTH_INV } \times \\
\text { OVERCON }_{t}\end{array}$ & & $\begin{array}{c}-0.011 * * * \\
(-4.51)\end{array}$ & & & $\begin{array}{c}-0.005 * * * \\
(-4.84)\end{array}$ & \\
\hline$A I M R \_S C O R E_{t}$ & & & $\begin{array}{c}0.031^{* * * *} \\
(10.25)\end{array}$ & & & $\begin{array}{c}0.021 * * * \\
(8.56)\end{array}$ \\
\hline $\begin{array}{l}\text { AIMR_SCORE } \times \\
\text { OVERCON }_{t}\end{array}$ & & & $\begin{array}{c}-\mathbf{0 . 0 4 0} * * * * \\
(-8.79)\end{array}$ & & & $\begin{array}{c}-0.029 * * * \\
(-15.86)\end{array}$ \\
\hline OVERCONFIDENCE $E_{t+1}$ & $\begin{array}{c}-0.162 * * * \\
(-7.15)\end{array}$ & $\begin{array}{c}-0.170 * * * \\
(-7.03)\end{array}$ & $\begin{array}{c}-0.024 * * * \\
(-7.25)\end{array}$ & $\begin{array}{c}-0.121 * * * \\
(-12.75)\end{array}$ & $\begin{array}{c}-0.112 * * * \\
(-10.50)\end{array}$ & $\begin{array}{c}-0.061 * * * \\
(-30.86)\end{array}$ \\
\hline$E Q U I T Y_{t+1}$ & $\begin{array}{c}-0.091 * * * \\
(-97.88)\end{array}$ & $\begin{array}{c}-0.091 * * * \\
(-97.82)\end{array}$ & $\begin{array}{r}-0.101 * * * \\
(-122.55)\end{array}$ & $\begin{array}{c}-0.098 * * * \\
(-94.82)\end{array}$ & $\begin{array}{c}-0.098 * * * \\
(-94.67)\end{array}$ & $\begin{array}{r}-0.107 * * * \\
(-100.19)\end{array}$ \\
\hline LOGASSETS $_{t}$ & $\begin{array}{c}0.017 * * * \\
(11.57)\end{array}$ & $\begin{array}{c}0.018 * * * \\
(12.14)\end{array}$ & $\begin{array}{c}0.012 * * * \\
(7.26)\end{array}$ & $\begin{array}{c}0.021 * * * \\
(14.88)\end{array}$ & $\begin{array}{c}0.022 * * * \\
(15.55)\end{array}$ & $\begin{array}{c}0.021 * * * \\
(13.36)\end{array}$ \\
\hline$M T B_{t}$ & $\begin{array}{c}0.001 * * * \\
(5.96)\end{array}$ & $\begin{array}{c}0.001 * * * \\
(6.20)\end{array}$ & $\begin{array}{c}-0.000 * * * \\
(-3.44)\end{array}$ & $\begin{array}{c}0.001 * * * \\
(5.70)\end{array}$ & $\begin{array}{c}0.001 * * * \\
(5.93)\end{array}$ & $\begin{array}{c}-0.000 * * * \\
(-3.65)\end{array}$ \\
\hline$S \& P 500_{t}$ & $\begin{array}{c}0.009 * * * \\
(3.16)\end{array}$ & $\begin{array}{c}0.007 * * * \\
(2.62)\end{array}$ & $\begin{array}{c}0.034 * * * \\
(14.26)\end{array}$ & $\begin{array}{c}0.009 * * * \\
(3.41)\end{array}$ & $\begin{array}{c}0.007 * * * \\
(2.73)\end{array}$ & $\begin{array}{c}0.032 * * * \\
(14.24)\end{array}$ \\
\hline$A_{N A L Y S T}$ & $\begin{array}{l}0.001 \\
(0.63)\end{array}$ & $\begin{array}{l}0.000 \\
(0.23)\end{array}$ & $\begin{array}{c}0.013 * * * \\
(8.70)\end{array}$ & $\begin{array}{l}0.000 \\
(0.14)\end{array}$ & $\begin{array}{l}-0.000 \\
(-0.17)\end{array}$ & $\begin{array}{c}0.013 * * * \\
(8.72)\end{array}$ \\
\hline SHAREHOLDERS $_{t}$ & $\begin{array}{l}-0.002 * \\
(-1.89)\end{array}$ & $\begin{array}{l}-0.001 \\
(-1.15)\end{array}$ & $\begin{array}{l}0.002 \\
(1.57)\end{array}$ & $\begin{array}{c}-0.006 * * * * \\
(-5.15)\end{array}$ & $\begin{array}{c}-0.005 * * * \\
(-4.34)\end{array}$ & $\begin{array}{c}-0.006 * * * \\
(-4.49)\end{array}$ \\
\hline$R O A_{t}$ & $\begin{array}{c}0.072 * * * \\
(5.82)\end{array}$ & $\begin{array}{c}0.074 * * * \\
(5.93)\end{array}$ & $\begin{array}{c}0.104 * * * \\
(6.32)\end{array}$ & $\begin{array}{c}0.084 * * * \\
(6.73)\end{array}$ & $\begin{array}{c}0.086 * * * \\
(6.84)\end{array}$ & $\begin{array}{c}0.156 * * * \\
(9.74)\end{array}$ \\
\hline$F F_{-} B E T A_{t+1}$ & $\begin{array}{c}-0.005 * * * \\
(-3.38)\end{array}$ & $\begin{array}{c}-0.005 * * * \\
(-2.97)\end{array}$ & $\begin{array}{c}-0.030 * * * \\
(-19.59)\end{array}$ & $\begin{array}{c}-0.006 * * * \\
(-4.22)\end{array}$ & $\begin{array}{c}-0.006 * * * \\
(-3.85)\end{array}$ & $\begin{array}{c}-0.034 * * * \\
(-22.94)\end{array}$ \\
\hline$R E T_{-} V O L_{t}$ & $\begin{array}{c}-0.244 * * * \\
(-7.79)\end{array}$ & $\begin{array}{c}-0.257 * * * \\
(-8.20)\end{array}$ & $\begin{array}{c}-0.075 * * * \\
(-2.97)\end{array}$ & $\begin{array}{c}-0.232 * * * \\
(-7.58)\end{array}$ & $\begin{array}{c}-0.249 * * * \\
(-8.11)\end{array}$ & $\begin{array}{c}-0.053 * * \\
(-2.17)\end{array}$ \\
\hline$E A R N_{-} V O L_{t}$ & $\begin{array}{c}0.105^{* * *} * \\
(4.64)\end{array}$ & $\begin{array}{c}0.125 * * * \\
(5.48)\end{array}$ & $\begin{array}{c}0.090^{* * *} \\
(2.36)\end{array}$ & $\begin{array}{c}0.085^{* * * *} \\
(3.81)\end{array}$ & $\begin{array}{c}0.109 * * * \\
(4.87)\end{array}$ & $\begin{array}{c}0.073 * * \\
(2.01)\end{array}$ \\
\hline$N B S E G_{t}$ & $\begin{array}{l}0.001 \\
(0.25)\end{array}$ & $\begin{array}{l}-0.000 \\
(-0.00)\end{array}$ & $\begin{array}{c}-0.022 * * * \\
(-10.22)\end{array}$ & $\begin{array}{l}0.001 \\
(0.45)\end{array}$ & $\begin{array}{l}0.000 \\
(0.15)\end{array}$ & $\begin{array}{c}-0.024 * * * \\
(-11.63)\end{array}$ \\
\hline$N G S E G_{t}$ & $\begin{array}{c}0.018 * * * \\
(3.64)\end{array}$ & $\begin{array}{c}0.017 * * * \\
(3.53)\end{array}$ & $\begin{array}{c}0.018 * * * \\
(3.18)\end{array}$ & $\begin{array}{c}0.019 * * * \\
(4.16)\end{array}$ & $\begin{array}{c}0.018 * * * \\
(3.79)\end{array}$ & $\begin{array}{c}0.029 * * * \\
(5.27)\end{array}$ \\
\hline$N_{I T E M S}$ & $\begin{array}{c}0.074 * * * \\
(7.59)\end{array}$ & $\begin{array}{c}0.078 * * * \\
(8.05)\end{array}$ & $\begin{array}{l}0.005 \\
(0.59)\end{array}$ & $\begin{array}{c}0.071 * * * \\
(7.59)\end{array}$ & $\begin{array}{c}0.076 * * * \\
(8.06)\end{array}$ & $\begin{array}{l}0.002 \\
(0.20)\end{array}$ \\
\hline $\operatorname{LOSS}_{t}$ & $\begin{array}{c}-0.008^{*} \\
(-1.74)\end{array}$ & $\begin{array}{c}-0.009^{*} \\
(-1.90)\end{array}$ & $\begin{array}{c}-0.018^{* * *} \\
(-7.95)\end{array}$ & $\begin{array}{l}-0.007 \\
(-1.59)\end{array}$ & $\begin{array}{c}-0.008^{*} \\
(-1.81)\end{array}$ & $\begin{array}{c}-0.006 * * * \\
(-3.00)\end{array}$ \\
\hline No. of Observations & 91,228 & 91,228 & 249,888 & 91,228 & 91,228 & 249,888 \\
\hline Adjusted $R^{2}$ & 0.32 & 0.32 & 0.32 & 0.37 & 0.37 & 0.39 \\
\hline
\end{tabular}


This table presents an analysis of the relation between individual investors' overconfidence, measured using BR_OVERCON and $A B \_O V E R C O N$, and the following three financial disclosure measures: annual report readability $\left(F O G_{-} I N V\right)$, annual report length $\left(L E N G T H_{-} I N V\right)$, and analysts' disclosure scores (AIMR_SCORE). $*, * *, * * *$ indicate significance at the $0.10,0.05$, and 0.01 levels, respectively, using two-tailed tests. $T$-statistics and $p$-values are calculated using clustered standard errors by individual investor account number. All regressions include year and industry fixed-effects; however, for brevity, these separate intercepts are not reported. See Appendix A for variable definitions. 
TABLE 17

Individual Investors' Shareholdings and Financial Disclosure: Disclosure Score SubComponents

\begin{tabular}{|c|c|c|c|}
\hline & \multicolumn{3}{|c|}{ Dependent Variable $=H O L D I N G S_{t+1}$} \\
\hline & I. & II. & III. \\
\hline$A N N U A L \_R E P O R T_{t}$ & $\begin{array}{c}0.036 * * * \\
(12.07)\end{array}$ & & \\
\hline${ }_{\text {INVESTOR_RELATIONS }}$ & & $\begin{array}{c}0.019 * * * \\
(7.24)\end{array}$ & \\
\hline OTHER_PUBLICATIONS $_{t}$ & & & $\begin{array}{c}0.012 * * * \\
(4.53)\end{array}$ \\
\hline EQUITY $_{t+1}$ & $\begin{array}{c}-0.105 * * * \\
(-126.62)\end{array}$ & $\begin{array}{c}-0.105 * * * \\
(-126.66)\end{array}$ & $\begin{array}{c}-0.105 * * * \\
(-126.51)\end{array}$ \\
\hline LOGASSETS $_{t}$ & $\begin{array}{c}0.012 * * * \\
(6.68)\end{array}$ & $\begin{array}{c}0.012 * * * \\
(7.06)\end{array}$ & $\begin{array}{c}0.013^{* * * *} \\
(7.68)\end{array}$ \\
\hline$M T B_{t}$ & $\begin{array}{c}-0.000 * * * \\
(-4.32)\end{array}$ & $\begin{array}{c}-0.000 * * * \\
(-4.65)\end{array}$ & $\begin{array}{c}-0.000 * * * \\
(-4.84)\end{array}$ \\
\hline$S \& P 500_{t}$ & $\begin{array}{c}0.033^{* * * *} \\
(13.23)\end{array}$ & $\begin{array}{c}0.034 * * * \\
(13.52)\end{array}$ & $\begin{array}{c}0.034 * * * \\
(13.59)\end{array}$ \\
\hline ANALYST $_{t}$ & $\begin{array}{c}0.017 * * * \\
(10.57)\end{array}$ & $\begin{array}{c}0.016^{* * * *} \\
(9.89)\end{array}$ & $\begin{array}{c}0.016^{* * *} \\
(9.79)\end{array}$ \\
\hline SHAREHOLDERS $_{t}$ & $\begin{array}{l}0.002 \\
(1.24)\end{array}$ & $\begin{array}{c}0.003 * * \\
(2.33)\end{array}$ & $\begin{array}{c}0.003 * * \\
(2.32)\end{array}$ \\
\hline$R O A_{t}$ & $\begin{array}{c}0.064 * * * \\
(3.57)\end{array}$ & $\begin{array}{c}0.101 * * * \\
(5.67)\end{array}$ & $\begin{array}{c}0.100 * * * \\
(5.61)\end{array}$ \\
\hline$F F \_B E T A_{t+1}$ & $\begin{array}{c}-0.029 * * * \\
(-18.60)\end{array}$ & $\begin{array}{c}-0.029 * * * \\
(-18.60)\end{array}$ & $\begin{array}{c}-0.029 * * * \\
(-18.30)\end{array}$ \\
\hline$R E T_{-} V O L_{t}$ & $\begin{array}{l}-0.013 \\
(-0.47)\end{array}$ & $\begin{array}{l}0.030 \\
(1.09)\end{array}$ & $\begin{array}{l}0.011 \\
(0.38)\end{array}$ \\
\hline$E A R N_{-} V O L_{t}$ & $\begin{array}{l}0.033 \\
(0.77)\end{array}$ & $\begin{array}{l}-0.020 \\
(-0.47)\end{array}$ & $\begin{array}{l}-0.026 \\
(-0.61)\end{array}$ \\
\hline$N B S E G_{t}$ & $\begin{array}{c}-0.026 * * * \\
(-12.03)\end{array}$ & $\begin{array}{c}-0.025 * * * \\
(-11.51)\end{array}$ & $\begin{array}{c}-0.027 * * * \\
(-12.02)\end{array}$ \\
\hline$N G S E G_{t}$ & $\begin{array}{l}0.006 \\
(1.03)\end{array}$ & $\begin{array}{l}0.009 \\
(1.56)\end{array}$ & $\begin{array}{l}0.004 \\
(0.73)\end{array}$ \\
\hline NITEMS $_{t}$ & $\begin{array}{l}-0.006 \\
(-0.55)\end{array}$ & $\begin{array}{l}0.000 \\
(0.01)\end{array}$ & $\begin{array}{l}0.004 \\
(0.38)\end{array}$ \\
\hline $\operatorname{LOSS}_{t}$ & $\begin{array}{c}-0.023 * * * \\
(-9.57)\end{array}$ & $\begin{array}{c}-0.022 * * * \\
(-9.32)\end{array}$ & $\begin{array}{c}-0.022 * * * * \\
(-9.45)\end{array}$ \\
\hline No. of Observations & 232,272 & 232,272 & 232,272 \\
\hline Adjusted $R^{2}$ & 0.31 & 0.31 & 0.31 \\
\hline
\end{tabular}

This table presents an analysis of the relation between individual investors' shareholdings and the following three disclosure score sub-components: ANNUAL_REPORT, INVESTOR_RELATIONS, and OTHER_PUBLICATIONS. *,**,*** indicate significance at the $0.10,0.05$, and 0.01 levels, respectively, using two-tailed tests. $T$-statistics and $p$-values are calculated using clustered standard errors by individual investor account number. All regressions include year and industry fixed-effects; however, for brevity, these separate intercepts are not reported. See Appendix A for variable definitions. 
TABLE 18

2SLS Regressions of Individual Investors' Shareholdings on Financial Disclosure

\begin{tabular}{|c|c|c|c|c|c|c|}
\hline & \multicolumn{2}{|c|}{$I$} & \multicolumn{2}{|c|}{$I I$} & \multicolumn{2}{|c|}{ III } \\
\hline & \multicolumn{6}{|c|}{ Dependent Variable $=$} \\
\hline & First-stage & Second-stage & First-stage & Second-stage & First-stage & Second-stage \\
\hline & $F O G \_I N V_{t}$ & HOLDINGS $S_{t+1}$ & $L E N G T H \_I N V_{t}$ & $H_{O L D I N G S}$ & $A I M R \_S C O R E_{t}$ & HOLDINGS $_{t+1}$ \\
\hline$F O G \_I N V_{t}$ & & $\begin{array}{c}0.081 * * * \\
(3.18)\end{array}$ & & & & \\
\hline$L E N G T H \_I N V_{t}$ & & & & $\begin{array}{c}0.078 * * * \\
(3.44)\end{array}$ & & \\
\hline$A I M R \_S C O R E_{t}$ & & & & & & $\begin{array}{c}0.414 * * * \\
(20.69)\end{array}$ \\
\hline \multicolumn{7}{|l|}{ Instruments } \\
\hline$S A L E S \_G R O W T H_{t}$ & $\begin{array}{c}-0.071 * * * \\
(-5.1)\end{array}$ & & $\begin{array}{c}-0.118 * * * \\
(-17.35)\end{array}$ & & $\begin{array}{c}0.190 * * * \\
(49.20)\end{array}$ & \\
\hline$O P \_M A R G I N_{t}$ & $\begin{array}{c}-0.022 * * * \\
(-6.81)\end{array}$ & & $\begin{array}{c}-0.009 * * * \\
(-5.69)\end{array}$ & & $\begin{array}{l}-0.003 \\
(-0.69)\end{array}$ & \\
\hline \multicolumn{7}{|l|}{ Control Variables } \\
\hline$E Q U I T Y_{t+1}$ & $\begin{array}{l}0.004 \\
(1.54)\end{array}$ & $\begin{array}{c}-0.097 * * * \\
(-175.74)\end{array}$ & $\begin{array}{c}0.002 * \\
(1.75)\end{array}$ & $\begin{array}{c}-0.097 * * * \\
(-187.51)\end{array}$ & $\begin{array}{c}-0.002 * * * \\
(-5.69)\end{array}$ & $\begin{array}{c}-0.105 * * * \\
(-278.59)\end{array}$ \\
\hline LOGASSETS $_{t}$ & $\begin{array}{c}0.029 * * * \\
(5.20)\end{array}$ & $\begin{array}{c}0.014 * * * \\
(10.63)\end{array}$ & $\begin{array}{c}-0.096 * * * \\
(-35.68)\end{array}$ & $\begin{array}{c}0.024 * * * \\
(9.45)\end{array}$ & $\begin{array}{c}0.060 * * * \\
(68.00)\end{array}$ & $\begin{array}{c}-0.004 * * \\
(-2.24)\end{array}$ \\
\hline$M T B_{t}$ & $\begin{array}{c}0.002 * * * \\
(3.81)\end{array}$ & $\begin{array}{c}0.001 * * * \\
(4.76)\end{array}$ & $\begin{array}{c}-0.001 * * * \\
(-4.84)\end{array}$ & $\begin{array}{c}0.001 * * * \\
(7.30)\end{array}$ & $\begin{array}{c}0.001 * * * \\
(17.74)\end{array}$ & $\begin{array}{c}-0.001 * * * \\
(-13.86)\end{array}$ \\
\hline$S \& P 500_{t}$ & $\begin{array}{c}0.304 * * * \\
(27.82)\end{array}$ & $\begin{array}{l}-0.009 \\
(-1.08)\end{array}$ & $\begin{array}{c}0.297 * * * \\
(55.48)\end{array}$ & $\begin{array}{l}-0.007 \\
(-1.00)\end{array}$ & $\begin{array}{c}0.053 * * * \\
(34.64)\end{array}$ & $\begin{array}{c}0.009 * * * \\
(4.55)\end{array}$ \\
\hline$A N A L Y S T_{t}$ & $\begin{array}{c}-0.265^{* * *} \\
(-30.19)\end{array}$ & $\begin{array}{c}0.026 * * * \\
(3.72)\end{array}$ & $\begin{array}{c}-0.058 * * * \\
(-13.42)\end{array}$ & $\begin{array}{c}0.009 * * * \\
(4.12)\end{array}$ & $\begin{array}{c}-0.049 * * * \\
(-44.53)\end{array}$ & $\begin{array}{c}0.034 * * * \\
(23.26)\end{array}$ \\
\hline$S_{H A R E H O L D E R S_{t}}$ & $\begin{array}{c}0.153 * * * \\
(34.27)\end{array}$ & $\begin{array}{c}-0.014 * * * \\
(-3.58)\end{array}$ & $\begin{array}{c}0.020 * * * \\
\quad(9.23)\end{array}$ & $\begin{array}{c}-0.004 * * * \\
(-3.68)\end{array}$ & $\begin{array}{c}0.023 * * * \\
(28.60)\end{array}$ & $\begin{array}{c}-0.008 * * * \\
(-9.51)\end{array}$ \\
\hline$R O A_{t}$ & $\begin{array}{c}0.661 * * * \\
(8.35)\end{array}$ & $\begin{array}{c}0.041^{* * * *} \\
(2.67)\end{array}$ & $\begin{array}{c}0.295^{* * *} \\
(7.62)\end{array}$ & $\begin{array}{c}0.058 * * * \\
(4.54)\end{array}$ & $\begin{array}{l}0.008 \\
(0.51)\end{array}$ & $\begin{array}{l}0.010 \\
(0.74)\end{array}$ \\
\hline
\end{tabular}




\begin{tabular}{|c|c|c|c|c|c|c|}
\hline$F F_{-} B E T A_{t+1}$ & $\begin{array}{c}0.0397 * * * \\
(5.79)\end{array}$ & $\begin{array}{c}-0.0085^{* * *} \\
(-5.02)\end{array}$ & $\begin{array}{c}-0.021 * * * \\
(-6.17)\end{array}$ & $\begin{array}{c}-0.004 * * * \\
(-2.81)\end{array}$ & $\begin{array}{c}0.015 * * * \\
(11.62)\end{array}$ & $\begin{array}{c}-0.020 * * * \\
(-15.52)\end{array}$ \\
\hline$R E T_{-} V O L_{t}$ & $\begin{array}{c}-3.3801 * * * \\
(-24.41)\end{array}$ & $\begin{array}{l}-0.0379 \\
(-0.40)\end{array}$ & $\begin{array}{c}-0.954 * * * \\
(-14.06)\end{array}$ & $\begin{array}{c}-0.234 * * * \\
(-6.12)\end{array}$ & $\begin{array}{c}0.383 * * * \\
(15.03)\end{array}$ & $\begin{array}{c}-0.189 * * * \\
(-7.22)\end{array}$ \\
\hline$E A R N_{-} V O L_{t}$ & $\begin{array}{c}2.5410 * * * \\
(26.47)\end{array}$ & $\begin{array}{c}-0.0946 \\
(-1.35)\end{array}$ & $\begin{array}{c}-1.661 * * * \\
(-35.35)\end{array}$ & $\begin{array}{c}0.248 * * * \\
(5.90)\end{array}$ & $\begin{array}{c}-1.905 * * * \\
(-62.82)\end{array}$ & $\begin{array}{c}0.849 * * * \\
(18.52)\end{array}$ \\
\hline$N B S E G_{t}$ & $\begin{array}{c}-0.5268 * * * \\
(-46.70)\end{array}$ & $\begin{array}{c}0.0304 * * \\
(2.24)\end{array}$ & $\begin{array}{c}-0.323 * * * \\
(-58.40)\end{array}$ & $\begin{array}{c}0.013^{*} \\
(1.69)\end{array}$ & $\begin{array}{c}-0.048 * * * \\
(-34.62)\end{array}$ & $\begin{array}{c}-0.008 * * * \\
(-4.28)\end{array}$ \\
\hline$N G S E G_{t}$ & $\begin{array}{c}0.2502 * * * \\
(12.82)\end{array}$ & $\begin{array}{c}0.0209^{* * * *} \\
(2.71)\end{array}$ & $\begin{array}{c}-0.068 * * * \\
(-7.10)\end{array}$ & $\begin{array}{c}0.046^{* * * *} \\
(11.06)\end{array}$ & $\begin{array}{c}-0.294 * * * \\
(-83.45)\end{array}$ & $\begin{array}{c}0.061 * * * \\
(8.88)\end{array}$ \\
\hline $\operatorname{NITEMS}_{t}$ & $\begin{array}{c}-0.1842 * * * \\
(-4.67)\end{array}$ & $\begin{array}{c}0.0895^{* * *} \\
(9.36)\end{array}$ & $\begin{array}{c}-0.496 * * * \\
(-25.71)\end{array}$ & $\begin{array}{c}0.115^{* * * *} \\
(8.18)\end{array}$ & $\begin{array}{c}-0.006 * * * \\
(-1.12)\end{array}$ & $\begin{array}{c}-0.018 * * * \\
(-3.24)\end{array}$ \\
\hline $\operatorname{LOSS}_{t}$ & $\begin{array}{c}-0.1358 * * * \\
(-5.82)\end{array}$ & $\begin{array}{c}0.0103 \\
(1.56)\end{array}$ & $\begin{array}{c}-0.084 * * * \\
(-7.33)\end{array}$ & $\begin{array}{l}0.004 \\
(0.76)\end{array}$ & $\begin{array}{c}-0.114 * * * \\
(-48.83)\end{array}$ & $\begin{array}{c}0.037 * * * \\
(11.34)\end{array}$ \\
\hline Adjusted $R^{2}$ & 0.09 & 0.21 & 0.11 & 0.29 & 0.19 & 0.18 \\
\hline Partial F-statistic & \multicolumn{2}{|c|}{$F_{p}=35.20 \quad(p<0.001)$} & \multicolumn{2}{|c|}{$F_{p}=163.37 \quad(p<0.001)$} & \multicolumn{2}{|c|}{$\mathrm{F}_{\mathrm{p}}=1,214.32 \quad(\mathrm{p}<0.001)$} \\
\hline Partial $R^{2}$ & \multicolumn{2}{|c|}{0.0008} & \multicolumn{2}{|c|}{0.0037} & \multicolumn{2}{|c|}{0.0100} \\
\hline Over-identifying test & \multicolumn{2}{|c|}{$\chi^{2}=1.39(\mathrm{p}=0.239)$} & \multicolumn{2}{|c|}{$\chi 2=0.93 \quad(p=0.336)$} & \multicolumn{2}{|c|}{$\chi 2=146.62(p<0.001)$} \\
\hline Hausman test & \multicolumn{2}{|c|}{$\mathrm{F}=9.99 \quad(\mathrm{p}=0.002)$} & \multicolumn{2}{|c|}{$\mathrm{F}=8.96 \quad(\mathrm{p}=0.003)$} & \multicolumn{2}{|c|}{$\mathrm{F}=426.81(\mathrm{p}<0.001)$} \\
\hline No. of Observations & \multicolumn{2}{|c|}{85,572} & \multicolumn{2}{|c|}{85,572} & \multicolumn{2}{|c|}{239,428} \\
\hline
\end{tabular}

This table presents an analysis of the relation between individual investors' shareholdings and the following three financial disclosure measures: annual report readability $\left(F O G \_I N V\right)$, annual report length $\left(L E N G T H \_I N V\right)$, and analysts' disclosure scores (AIMR_SCORE) using 2SLS regressions. The firststage models the financial disclosure measure and the second-stage measure models individual investors' shareholdings. *, **, *** indicate significance at the 0.10, 0.05, and 0.01 levels, respectively, using two-tailed tests. The partial F-statistic and partial $\mathrm{R}^{2}$ correspond to the first-stage regression. See Appendix for variable definitions. 
TABLE 19

Individual Investors' Shareholdings and Financial Disclosure: Performed at the Household Level

\begin{tabular}{|c|c|c|c|}
\hline & \multicolumn{3}{|c|}{ Dependent Variable $=H O L D I N G S_{t+1}$} \\
\hline & I. & II. & III. \\
\hline$F O G_{-} I N V_{t}$ & $\begin{array}{c}0.003 * * * \\
(5.22)\end{array}$ & & \\
\hline$L E N G T H \_I N V_{t}$ & & $\begin{array}{c}\mathbf{0 . 0 0 6} * * * \\
(\mathbf{5 . 5 4})\end{array}$ & \\
\hline$A I M R \_S C O R E_{t}$ & & & $\begin{array}{c}\mathbf{0 . 0 1 6} * * * \\
(7.36)\end{array}$ \\
\hline$E Q U I T Y_{t+1}$ & $\begin{array}{c}-0.071 * * * \\
(-98.61)\end{array}$ & $\begin{array}{c}-0.071 * * * \\
(-98.59)\end{array}$ & $\begin{array}{c}-0.082 * * * \\
(-120.99)\end{array}$ \\
\hline LOGASSETS $_{t}$ & $\begin{array}{c}0.013 * * * \\
(10.58)\end{array}$ & $\begin{array}{c}0.013 * * * \\
(11.00)\end{array}$ & $\begin{array}{c}0.011 * * * \\
(7.81)\end{array}$ \\
\hline$M T B_{t}$ & $\begin{array}{c}0.000 * * * \\
(5.78)\end{array}$ & $\begin{array}{c}0.001 * * * \\
(5.95)\end{array}$ & $\begin{array}{c}-0.000 * * * \\
(-3.80)\end{array}$ \\
\hline$S \& P 500_{t}$ & $\begin{array}{c}0.010 * * * \\
(4.20)\end{array}$ & $\begin{array}{c}0.008 * * * \\
(3.73)\end{array}$ & $\begin{array}{c}0.026 * * * \\
(12.60)\end{array}$ \\
\hline$A N A L Y S T_{t}$ & $\begin{array}{l}-0.000 \\
(-0.12)\end{array}$ & $\begin{array}{l}-0.000 \\
(-0.23)\end{array}$ & $\begin{array}{c}0.010 * * * \\
(7.49)\end{array}$ \\
\hline SHAREHOLDERS $_{t}$ & $\begin{array}{l}-0.001 \\
(-1.26)\end{array}$ & $\begin{array}{l}-0.001 \\
(-0.72)\end{array}$ & $\begin{array}{l}-0.001 \\
(-0.95)\end{array}$ \\
\hline$R O A_{t}$ & $\begin{array}{c}0.028 * * * \\
(2.99)\end{array}$ & $\begin{array}{c}0.029 * * * \\
(3.10)\end{array}$ & $\begin{array}{c}0.071 * * * \\
(5.16)\end{array}$ \\
\hline$F F_{-} B E T A_{t+1}$ & $\begin{array}{c}-0.002 * * \\
(-2.03)\end{array}$ & $\begin{array}{c}-0.002 * \\
(-1.76)\end{array}$ & $\begin{array}{c}-0.025 * * * \\
(-20.17)\end{array}$ \\
\hline$R E T_{-} V O L_{t}$ & $\begin{array}{c}-0.230 * * * \\
(-9.24)\end{array}$ & $\begin{array}{c}-0.238 * * * \\
(-9.55)\end{array}$ & $\begin{array}{c}-0.097 * * * \\
(-4.59)\end{array}$ \\
\hline$E A R N_{-} V O L_{t}$ & $\begin{array}{c}0.055^{* * *} * \\
(3.19)\end{array}$ & $\begin{array}{c}0.070 * * * \\
(4.07)\end{array}$ & $\begin{array}{l}0.013 \\
(0.39)\end{array}$ \\
\hline$N B S E G_{t}$ & $\begin{array}{l}0.001 \\
(0.45)\end{array}$ & $\begin{array}{l}0.001 \\
(0.47)\end{array}$ & $\begin{array}{c}-0.012 * * * \\
(-6.78)\end{array}$ \\
\hline$N G S E G_{t}$ & $\begin{array}{c}0.008 * * \\
(2.14)\end{array}$ & $\begin{array}{l}0.008^{*} \\
(1.95)\end{array}$ & $\begin{array}{l}0.008^{*} \\
(1.69)\end{array}$ \\
\hline NITEMS $_{t}$ & $\begin{array}{c}0.041 * * * \\
(5.31)\end{array}$ & $\begin{array}{c}0.044 * * * \\
(5.69)\end{array}$ & $\begin{array}{l}-0.009 \\
(-1.21)\end{array}$ \\
\hline $\operatorname{LOSS}_{t}$ & $\begin{array}{c}-0.010 * * * \\
(-2.68)\end{array}$ & $\begin{array}{c}-0.010 * * * \\
(-2.78)\end{array}$ & $\begin{array}{c}-0.016 * * * \\
(-8.23)\end{array}$ \\
\hline No. of Observations & 91,273 & 91,273 & 250,005 \\
\hline Adjusted $R^{2}$ & 0.29 & 0.29 & 0.29 \\
\hline
\end{tabular}

This table presents an analysis of the relation between individual investors' shareholdings, measured at the household level, and the following three financial disclosure measures: annual report readability (FOG_INV), annual report length (LENGTH_INV), and analysts' disclosure scores (AIMR_SCORE). *, **, *** indicate significance at the $0.10,0.05$, and 0.01 levels, respectively, using two-tailed tests. $T$-statistics and $p$-values are calculated using clustered standard errors by individual investor account number. All regressions include year and industry fixed-effects; however, for brevity, these separate intercepts are not reported. See Appendix A for variable definitions. 
TABLE 20

Individual Investors' Shareholdings and Financial Disclosure: Six Month Holding Window

\begin{tabular}{|c|c|c|c|}
\hline & \multicolumn{3}{|c|}{ Dependent Variable $=H O L D I N G S_{t+1}$} \\
\hline & I. & II. & III. \\
\hline$F O G \_I N V_{t}$ & $\begin{array}{c}0.004 * * * \\
(5.09)\end{array}$ & & \\
\hline$L E N G T H \_I N V_{t}$ & & $\begin{array}{c}0.007 * * * \\
(4.21)\end{array}$ & \\
\hline$A I M R \_S C O R E_{t}$ & & & $\begin{array}{c}0.034 * * * \\
(11.77)\end{array}$ \\
\hline$E Q U I T Y_{t+1}$ & $\begin{array}{c}-0.108 * * * \\
(-102.54)\end{array}$ & $\begin{array}{c}-0.108 * * * \\
(-102.49)\end{array}$ & $\begin{array}{c}-0.116 * * * \\
(-125.14)\end{array}$ \\
\hline LOGASSETS $_{t}$ & $\begin{array}{c}0.023 * * * \\
(13.50)\end{array}$ & $\begin{array}{c}0.023 * * * \\
(13.92)\end{array}$ & $\begin{array}{c}0.020 * * * \\
(11.06)\end{array}$ \\
\hline$M T B_{t}$ & $\begin{array}{c}0.001 * * * \\
(6.54)\end{array}$ & $\begin{array}{c}0.001 * * * \\
(6.72)\end{array}$ & $\begin{array}{c}-0.000 * * * \\
(-4.33)\end{array}$ \\
\hline$S \& P 500_{t}$ & $\begin{array}{c}0.013 * * * \\
(3.93)\end{array}$ & $\begin{array}{c}0.012 * * * \\
(3.61)\end{array}$ & $\begin{array}{c}0.030 * * * \\
(10.74)\end{array}$ \\
\hline ANALYST $_{t}$ & $\begin{array}{c}0.004 * \\
(1.71)\end{array}$ & $\begin{array}{l}0.003 \\
(1.37)\end{array}$ & $\begin{array}{c}0.019 * * * \\
(11.45)\end{array}$ \\
\hline SHAREHOLDERS $_{t}$ & $\begin{array}{c}-0.009 * * * * \\
(-6.79)\end{array}$ & $\begin{array}{c}-0.008 * * * \\
(-6.23)\end{array}$ & $\begin{array}{c}-0.003 * * \\
(-2.35)\end{array}$ \\
\hline$R O A_{t}$ & $\begin{array}{c}0.075^{* * *} * \\
(5.30)\end{array}$ & $\begin{array}{c}0.076 * * * \\
(5.35)\end{array}$ & $\begin{array}{c}0.203 * * * \\
(11.00)\end{array}$ \\
\hline$F F_{-} B E T A_{t+1}$ & $\begin{array}{l}-0.001 \\
(-0.54)\end{array}$ & $\begin{array}{l}-0.000 \\
(-0.26)\end{array}$ & $\begin{array}{c}-0.026 * * * \\
(-15.47)\end{array}$ \\
\hline$R E T_{-} V O L_{t}$ & $\begin{array}{c}-0.345^{* * * *} \\
(-9.54)\end{array}$ & $\begin{array}{c}-0.358 * * * \\
(-9.90)\end{array}$ & $\begin{array}{c}-0.134 * * * \\
(-4.78)\end{array}$ \\
\hline$E A R N_{-} V O L_{t}$ & $\begin{array}{c}0.080 * * * \\
(3.05)\end{array}$ & $\begin{array}{c}0.097 * * * \\
(3.66)\end{array}$ & $\begin{array}{l}0.002 \\
(0.05)\end{array}$ \\
\hline$N B S E G_{t}$ & $\begin{array}{l}-0.001 \\
(-0.25)\end{array}$ & $\begin{array}{l}-0.002 \\
(-0.53)\end{array}$ & $\begin{array}{c}-0.030 * * * \\
(-12.69)\end{array}$ \\
\hline$N G S E G_{t}$ & $\begin{array}{l}0.008 \\
(1.49)\end{array}$ & $\begin{array}{l}0.008 \\
(1.44)\end{array}$ & $\begin{array}{c}0.003 \\
(0.45)\end{array}$ \\
\hline NITEMS $_{t}$ & $\begin{array}{c}0.072 * * * \\
(6.48)\end{array}$ & $\begin{array}{c}0.075^{* * *} * \\
(6.75)\end{array}$ & $\begin{array}{l}-0.002 \\
(-0.16)\end{array}$ \\
\hline $\operatorname{LOSS}_{t}$ & $\begin{array}{c}-0.017 * * * \\
(-3.29)\end{array}$ & $\begin{array}{c}-0.017 * * * \\
(-3.43)\end{array}$ & $\begin{array}{l}0.003 \\
(1.22)\end{array}$ \\
\hline No. of Observations & 75,975 & 75,975 & 209,133 \\
\hline Adjusted $R^{2}$ & 0.34 & 0.34 & 0.34 \\
\hline
\end{tabular}

This table presents an analysis of the relation between individual investors' shareholdings, measured over a six month window, and the following three financial disclosure measures: annual report readability $\left(F O G \_I N V\right)$, annual report length $\left(L E N G T H \_I N V\right)$, and analysts' disclosure scores $\left(A I M R \_S C O R E\right)$. *, **, *** indicate significance at the $0.10,0.05$, and 0.01 levels, respectively, using two-tailed tests. $T$-statistics and $p$-values are calculated using clustered standard errors by individual investor account number. All regressions include year and industry fixed-effects; however, for brevity, these separate intercepts are not reported. See Appendix A for variable definitions. 
TABLE 21

Individual Investors' Shareholdings and Financial Disclosure: Without EQUITY

\begin{tabular}{|c|c|c|c|}
\hline & \multicolumn{3}{|c|}{ Dependent Variable $=H O L D I N G S_{t+1}$} \\
\hline & I. & II. & III. \\
\hline$F O G_{-} I N V_{t}$ & $\begin{array}{c}0.002 * * \\
(2.27)\end{array}$ & & \\
\hline LENGTH_INV $V_{t}$ & & $\begin{array}{c}0.005 * * * \\
(2.81)\end{array}$ & \\
\hline AIMR_SCORE ${ }_{t}$ & & & $\begin{array}{c}0.018 * * * \\
(5.81)\end{array}$ \\
\hline LOGASSETS $_{t}$ & $\begin{array}{c}0.009 * * * \\
(5.16)\end{array}$ & $\begin{array}{c}0.010 * * * \\
(5.37)\end{array}$ & $\begin{array}{l}-0.000 \\
(-0.00)\end{array}$ \\
\hline$M T B_{t}$ & $\begin{array}{c}0.000 * * \\
(2.37)\end{array}$ & $\begin{array}{c}0.000^{* *} \\
(2.46)\end{array}$ & $\begin{array}{l}0.000 \\
(0.38)\end{array}$ \\
\hline$S \& P 500_{t}$ & $\begin{array}{c}0.008 * * \\
(2.39)\end{array}$ & $\begin{array}{c}0.007 * * \\
(2.14)\end{array}$ & $\begin{array}{c}0.032 * * * \\
(11.24)\end{array}$ \\
\hline$A N A L Y S T_{t}$ & $\begin{array}{l}-0.002 \\
(-1.03)\end{array}$ & $\begin{array}{l}-0.002 \\
(-1.04)\end{array}$ & $\begin{array}{c}0.013 * * * \\
(7.04)\end{array}$ \\
\hline SHAREHOLDERS $_{t}$ & $\begin{array}{c}0.010 * * * \\
(7.27)\end{array}$ & $\begin{array}{c}0.010 * * * \\
(7.59)\end{array}$ & $\begin{array}{c}0.021 * * * \\
(13.22)\end{array}$ \\
\hline$R O A_{t}$ & $\begin{array}{l}0.010 \\
(0.70)\end{array}$ & $\begin{array}{l}0.011 \\
(0.75)\end{array}$ & $\begin{array}{c}0.110 * * * \\
(5.55)\end{array}$ \\
\hline$F F_{-} B E T A_{t+1}$ & $\begin{array}{c}-0.008 * * * \\
(-4.36)\end{array}$ & $\begin{array}{c}-0.008 * * * \\
(-4.24)\end{array}$ & $\begin{array}{c}-0.015 * * * \\
(-8.13)\end{array}$ \\
\hline$R E T_{-} V O L_{t}$ & $\begin{array}{l}0.045 \\
(1.17)\end{array}$ & $\begin{array}{l}0.040 \\
(1.04)\end{array}$ & $\begin{array}{c}0.077 * * \\
(2.56)\end{array}$ \\
\hline$E A R N_{-} V O L_{t}$ & $\begin{array}{c}0.115^{* * *} \\
(4.30)\end{array}$ & $\begin{array}{c}0.126^{* * * *} \\
(4.70)\end{array}$ & $\begin{array}{c}0.329 * * * \\
(7.18)\end{array}$ \\
\hline$N B S E G_{t}$ & $\begin{array}{c}-0.010^{* * * *} \\
(-3.33)\end{array}$ & $\begin{array}{c}-0.010 * * * \\
(-3.27)\end{array}$ & $\begin{array}{c}-0.039 * * * \\
(-14.93)\end{array}$ \\
\hline$N G S E G_{t}$ & $\begin{array}{l}0.008 \\
(1.30)\end{array}$ & $\begin{array}{l}0.007 \\
(1.22)\end{array}$ & $\begin{array}{l}0.011 \\
(1.55)\end{array}$ \\
\hline NITEMS $_{t}$ & $\begin{array}{c}0.077 * * * \\
(6.59)\end{array}$ & $\begin{array}{c}0.079 * * * \\
(6.79)\end{array}$ & $\begin{array}{c}0.006 \\
(0.57)\end{array}$ \\
\hline $\operatorname{LOSS}_{t}$ & $\begin{array}{l}-0.002 \\
(-0.45)\end{array}$ & $\begin{array}{l}-0.003 \\
(-0.48)\end{array}$ & $\begin{array}{c}-0.006^{* *} \\
(-2.40)\end{array}$ \\
\hline No. of Observations & 91,228 & 91,228 & 249,888 \\
\hline Adjusted $R^{2}$ & 0.03 & 0.03 & 0.04 \\
\hline
\end{tabular}

This table presents an analysis of the relation between individual investors' shareholdings and the following three financial disclosure measures: annual report readability $\left(F O G_{-} I N V\right)$, annual report length $\left(L E N G T H \_I N V\right)$, and analysts' disclosure scores (AIMR_SCORE), without controlling for individuals' portfolio holdings (EQUITY). *, **, *** indicate significance at the $0.10,0.05$, and 0.01 levels, respectively, using two-tailed tests. $T$-statistics and $p$-values are calculated using clustered standard errors by individual investor account number. All regressions include year and industry fixed-effects; however, for brevity, these separate intercepts are not reported. See Appendix A for variable definitions. 
TABLE 22

Individual Investors' Shareholdings and Financial Disclosure: EDGAR Mandatory Filings

\begin{tabular}{|c|c|c|}
\hline & \multicolumn{2}{|c|}{ Dependent Variable $=H O L D I N G S_{t+}$} \\
\hline & I. & II. \\
\hline$F O G_{-} I N V_{t}$ & $\begin{array}{c}0.005 * * * \\
(6.54)\end{array}$ & \\
\hline LENGTH_INV & & $\begin{array}{c}0.011 * * * \\
(6.87)\end{array}$ \\
\hline$A I M R \_S C O R E_{t}$ & $\begin{array}{c}-0.097 * * * \\
(-106.81)\end{array}$ & $\begin{array}{c}-0.097 * * * \\
(-106.71)\end{array}$ \\
\hline LOGASSETS $_{t}$ & $\begin{array}{c}0.015^{* * *} \\
(9.95)\end{array}$ & $\begin{array}{c}0.016^{* * *} \\
(10.58)\end{array}$ \\
\hline$M T B_{t}$ & $\begin{array}{c}0.000 * * * \\
(3.14)\end{array}$ & $\begin{array}{c}0.000 * * * \\
(3.21)\end{array}$ \\
\hline$S \& P 50 O_{t}$ & $\begin{array}{c}0.009 * * * \\
(3.28)\end{array}$ & $\begin{array}{c}0.008 * * * \\
(2.91)\end{array}$ \\
\hline ANALYST $_{t}$ & $\begin{array}{l}0.003 \\
(1.52)\end{array}$ & $\begin{array}{l}0.003 \\
(1.39)\end{array}$ \\
\hline SHAREHOLDERS $_{t}$ & $\begin{array}{l}0.001 \\
(0.43)\end{array}$ & $\begin{array}{l}0.001 \\
(1.01)\end{array}$ \\
\hline$R O A_{t}$ & $\begin{array}{l}0.022^{*} \\
(1.75)\end{array}$ & $\begin{array}{l}0.020 \\
(1.63)\end{array}$ \\
\hline$F F_{-} B E T A_{t+1}$ & $\begin{array}{c}-0.012 * * * \\
(-6.85)\end{array}$ & $\begin{array}{c}-0.012 * * * \\
(-6.71)\end{array}$ \\
\hline$R E T_{-} V O L_{t}$ & $\begin{array}{c}-0.169 * * * \\
(-5.11)\end{array}$ & $\begin{array}{c}-0.174 * * * \\
(-5.26)\end{array}$ \\
\hline$E A R N_{-} V O L_{t}$ & $\begin{array}{c}0.111 * * * \\
(4.45)\end{array}$ & $\begin{array}{c}0.137 * * * \\
(5.46)\end{array}$ \\
\hline$N B S E G_{t}$ & $\begin{array}{c}0.007 * * \\
(2.51)\end{array}$ & $\begin{array}{c}0.007 * * \\
(2.51)\end{array}$ \\
\hline$N G S E G_{t}$ & $\begin{array}{l}0.004 \\
(0.72)\end{array}$ & $\begin{array}{l}0.001 \\
(0.29)\end{array}$ \\
\hline NITEMS $_{t}$ & $\begin{array}{c}0.079 * * * \\
(7.28)\end{array}$ & $\begin{array}{c}0.083 * * * \\
(7.70)\end{array}$ \\
\hline $\operatorname{LOSS}_{t}$ & $\begin{array}{c}-0.018 * * * * \\
(-3.42)\end{array}$ & $\begin{array}{c}-0.020 * * * \\
(-3.74)\end{array}$ \\
\hline No. of Observations & 75,912 & 75,912 \\
\hline Adjusted $R^{2}$ & 0.32 & 0.32 \\
\hline
\end{tabular}

This table presents an analysis of the relation between individual investors' shareholdings and the following two financial disclosure measures: annual report readability $\left(F O G_{-} I N V\right)$ and annual report length $($ LENGTH_INV), post January 30, 1995 when EDGAR filings were mandatory. *, **, *** indicate significance at the $0.10,0.05$, and 0.01 levels, respectively, using two-tailed tests. $T$-statistics and $p$-values are calculated using clustered standard errors by individual investor account number. All regressions include year and industry fixed-effects; however, for brevity, these separate intercepts are not reported. See Appendix A for variable definitions. 
TABLE 23

Trading Consistency Analyses: Descriptive Statistics

\begin{tabular}{rcccccccc}
\hline \hline & \multicolumn{3}{c}{ Recommendation Sample } & \multicolumn{3}{c}{ Earnings Forecast Sample } \\
\cline { 2 - 9 } Variable & $\boldsymbol{N}$ & Mean & Median & STD & $\boldsymbol{N}$ & Mean & Median & STD \\
\hline IN_LINE & 33,909 & 0.46 & 0.00 & 0.50 & 173,124 & 0.48 & 0.00 & 0.50 \\
IND_PAST_RET & 33,909 & 0.00 & 0.00 & 0.02 & 173,124 & 0.00 & 0.00 & 0.02 \\
IND_EQUITY & 33,909 & 6.68 & 9.23 & 5.22 & 173,124 & 6.66 & 9.21 & 5.22 \\
TRADE_FREQ & 33,909 & 2.78 & 2.64 & 1.31 & 173,124 & 2.78 & 2.64 & 1.31 \\
GENDER & 19,601 & 0.09 & 0.00 & 0.28 & 99,469 & 0.09 & 0.00 & 0.29 \\
AGE & 18,436 & 50.32 & 48.00 & 12.61 & 93,733 & 50.47 & 48.00 & 12.75 \\
ABS_CHG & 33,909 & 1.23 & 1.00 & 0.56 & 173,124 & 1.03 & 0.40 & 7.07 \\
LOGMARKET & 33,909 & 8.63 & 8.76 & 1.74 & 173,124 & 8.61 & 8.73 & 1.69 \\
$P / E$ & 33,909 & 25.80 & 18.23 & 73.89 & 173,124 & 25.53 & 17.80 & 108.05 \\
RET_VOL & 33,909 & 0.03 & 0.02 & 0.01 & 173,124 & 0.03 & 0.02 & 0.01 \\
RAW_RET & 33,909 & 0.30 & 0.16 & 0.74 & 173,124 & 0.30 & 0.17 & 0.71 \\
BETA & 33,909 & 1.15 & 1.13 & 0.66 & 173,124 & 1.14 & 1.11 & 0.67 \\
ROE & 33,909 & 0.12 & 0.17 & 1.15 & 173,124 & 0.15 & 0.18 & 0.92 \\
ANALYST_PERF & 33,909 & 0.00 & 0.00 & 0.01 & 173,124 & 0.00 & 0.00 & 0.01 \\
BROKER_SIZE & 33,909 & 78.27 & 39.00 & 100.00 & 173,124 & 41.02 & 34.00 & 33.42 \\
\hline \hline
\end{tabular}

This table presents the descriptive statistics for the Recommendation and Earnings Forecast Samples. These samples only include analyst guidance that are either upgrades or downgrades and trades that are made in event days -1 to +1 . See Appendix B for variable definitions. 
TABLE 24

Trading Consistency Regression Analyses: Recommendations and Earnings Forecast Revisions

\begin{tabular}{|c|c|c|c|c|c|c|}
\hline & \multicolumn{6}{|c|}{ Dependent Variable $=I N \_L I N E$} \\
\hline & $\begin{array}{c}\text { All } \\
\text { Guidance } \\
\text { I. } \\
\end{array}$ & $\begin{array}{c}\text { Upgrades } \\
\text { II. }\end{array}$ & $\begin{array}{c}\text { Downgrades } \\
\text { III. }\end{array}$ & $\begin{array}{c}\text { All } \\
\text { Guidance } \\
\text { IV. } \\
\end{array}$ & $\begin{array}{c}\text { Upgrades } \\
\text { V. }\end{array}$ & $\begin{array}{c}\text { Downgrades } \\
\text { VI. }\end{array}$ \\
\hline IND_PAST_RET & $\begin{array}{c}-0.598 * * * \\
(-3.30)\end{array}$ & $\begin{array}{l}0.406 \\
(1.32)\end{array}$ & $\begin{array}{c}-1.278 * * * \\
(-4.91)\end{array}$ & $\begin{array}{c}-0.620 * * \\
(-2.51)\end{array}$ & $\begin{array}{c}0.887 * * \\
(1.97)\end{array}$ & $\begin{array}{c}-1.625 * * * \\
(-4.52)\end{array}$ \\
\hline IND_EQUITY & $\begin{array}{l}0.001 \\
(1.44)\end{array}$ & $\begin{array}{c}-0.015^{* * * *} \\
(-8.87)\end{array}$ & $\begin{array}{c}0.012 * * * * \\
(8.27)\end{array}$ & $\begin{array}{l}0.001 \\
(0.97)\end{array}$ & $\begin{array}{c}-0.015^{* * * *} \\
(-6.45)\end{array}$ & $\begin{array}{c}0.012 * * * \\
(5.93)\end{array}$ \\
\hline$T R A D E \_F R E Q$ & $\begin{array}{c}0.018 * * * \\
(4.33)\end{array}$ & $\begin{array}{c}-0.013^{*} \\
(-1.66)\end{array}$ & $\begin{array}{c}0.038 * * * \\
(5.37)\end{array}$ & $\begin{array}{c}0.017 * * * \\
(2.96)\end{array}$ & $\begin{array}{l}-0.015 \\
(-1.50)\end{array}$ & $\begin{array}{c}0.037 * * * \\
(3.79)\end{array}$ \\
\hline GENDER & & & & $\begin{array}{l}0.041^{*} \\
(1.74)\end{array}$ & $\begin{array}{l}-0.006 \\
(-0.15)\end{array}$ & $\begin{array}{c}0.068 * * \\
(2.01)\end{array}$ \\
\hline$A G E$ & & & & $\begin{array}{c}-0.001 * * \\
(-2.30)\end{array}$ & $\begin{array}{c}0.003^{* * * *} \\
(3.15)\end{array}$ & $\begin{array}{c}-0.004 * * * \\
(-4.91)\end{array}$ \\
\hline$A B S \_R E C \_C H G$ & $\begin{array}{c}-0.042 * * * \\
(-4.42)\end{array}$ & $\begin{array}{l}-0.003 \\
(-1.16)\end{array}$ & $\begin{array}{c}-0.025^{* *} \\
(-2.14)\end{array}$ & $\begin{array}{c}-0.056 * * * \\
(-8.40)\end{array}$ & $\begin{array}{l}-0.004 \\
(-0.99)\end{array}$ & $\begin{array}{c}-0.044 * * * \\
(-6.57)\end{array}$ \\
\hline LOGMARKET & $\begin{array}{c}-0.013 * * * \\
(-2.80)\end{array}$ & $\begin{array}{c}0.082 * * * \\
(11.10)\end{array}$ & $\begin{array}{c}-0.075^{* * * *} \\
(-10.49)\end{array}$ & $\begin{array}{l}-0.009 \\
(-1.51)\end{array}$ & $\begin{array}{c}0.092 * * * \\
(9.18)\end{array}$ & $\begin{array}{c}-0.074 * * * \\
(-8.53)\end{array}$ \\
\hline$P / E$ & $\begin{array}{c}-0.000 * * \\
(-2.20)\end{array}$ & $\begin{array}{l}0.000 * \\
(1.70)\end{array}$ & $\begin{array}{c}-0.000 * * * \\
(-2.78)\end{array}$ & $\begin{array}{c}-0.000 * * * \\
(-3.57)\end{array}$ & $\begin{array}{l}0.000 \\
(0.78)\end{array}$ & $\begin{array}{c}-0.000 * * * \\
(-3.30)\end{array}$ \\
\hline$R E T \_V O L$ & $\begin{array}{c}-7.524 * * * \\
(-9.71)\end{array}$ & $\begin{array}{c}17.071^{* * *} \\
(12.37)\end{array}$ & $\begin{array}{c}-20.115^{* * *} \\
(-18.02)\end{array}$ & $\begin{array}{c}-9.117 * * * \\
(-8.91)\end{array}$ & $\begin{array}{c}18.282^{* * *} \\
(9.88)\end{array}$ & $\begin{array}{c}-23.281 * * * \\
(-15.99)\end{array}$ \\
\hline$R A W \_R E T$ & $\begin{array}{c}0.094 * * * \\
(11.77)\end{array}$ & $\begin{array}{l}-0.004 \\
(-0.36)\end{array}$ & $\begin{array}{c}0.143 * * * \\
(11.12)\end{array}$ & $\begin{array}{c}0.093 * * * \\
(8.97)\end{array}$ & $\begin{array}{l}0.000 \\
(0.02)\end{array}$ & $\begin{array}{c}0.139 * * * \\
(8.85)\end{array}$ \\
\hline BETA & $\begin{array}{l}-0.004 \\
(-0.49)\end{array}$ & $\begin{array}{c}0.138 * * * \\
(10.28)\end{array}$ & $\begin{array}{c}-0.076 * * * \\
(-6.40)\end{array}$ & $\begin{array}{l}-0.003 \\
(-0.30)\end{array}$ & $\begin{array}{c}0.137 * * * \\
(7.60)\end{array}$ & $\begin{array}{c}-0.071 * * * \\
(-4.41)\end{array}$ \\
\hline$R O E$ & $\begin{array}{c}-0.011^{* *} \\
(-2.01)\end{array}$ & $\begin{array}{c}0.050 * * * \\
(2.65)\end{array}$ & $\begin{array}{c}-0.030^{* *} \\
(-2.31)\end{array}$ & $\begin{array}{c}-0.021^{* *} \\
(-2.41)\end{array}$ & $\begin{array}{c}0.055^{* *} \\
(1.98)\end{array}$ & $\begin{array}{c}-0.048 * * * \\
(-2.66)\end{array}$ \\
\hline ANALYST_PERF & $\begin{array}{l}-0.817^{*} \\
(-1.82)\end{array}$ & $\begin{array}{l}-1.136 \\
(-1.64)\end{array}$ & $\begin{array}{l}-0.594 \\
(-1.00)\end{array}$ & $\begin{array}{l}-0.613 \\
(-1.02)\end{array}$ & $\begin{array}{l}-0.416 \\
(-0.44)\end{array}$ & $\begin{array}{l}-0.478 \\
(-0.60)\end{array}$ \\
\hline BROKER_SIZE & $\begin{array}{c}-0.001 * * * \\
(-6.67)\end{array}$ & $\begin{array}{l}-0.000 \\
(-0.38)\end{array}$ & $\begin{array}{c}-0.001 * * * \\
(-6.98)\end{array}$ & $\begin{array}{c}-0.001 * * * \\
(-4.61)\end{array}$ & $\begin{array}{l}0.000 \\
(0.34)\end{array}$ & $\begin{array}{c}-0.001 * * * \\
(-5.33)\end{array}$ \\
\hline RECOMMENDATION & $\begin{array}{c}-0.027 * * \\
(-2.07)\end{array}$ & $\begin{array}{c}-0.051 * * * \\
(-2.75)\end{array}$ & $\begin{array}{c}-0.077 * * * \\
(-4.65)\end{array}$ & $\begin{array}{l}-0.024 \\
(-1.41)\end{array}$ & $\begin{array}{c}-0.054 * * \\
(-2.14)\end{array}$ & $\begin{array}{c}-0.072 * * * \\
(-3.18)\end{array}$ \\
\hline No. of Observations & 207,033 & 78,925 & 128,108 & 112,169 & 42,873 & 69,296 \\
\hline Psuedo $R^{2}$ & 0.01 & 0.01 & 0.02 & 0.01 & 0.01 & 0.02 \\
\hline
\end{tabular}

This table presents an analysis of the determinants of whether individuals trade in line with analysts' earnings forecasts and recommendations using logistic regressions. These regressions only include analyst guidance that are either upgrades or downgrades and trades that are made in event days -1 to +1 . *, **, *** indicate significance at the $0.10,0.05$, and 0.01 levels, respectively, using two-tailed tests. $T$-statistics and $p$-values are calculated using clustered standard errors by individual investor account number. All regressions include year and industry fixedeffects; however, for brevity, these separate intercepts are not reported. See Appendix B for variable definitions. 
TABLE 25

Trading Consistency Regression Analyses: Analysts' Recommendation Revisions

\begin{tabular}{|c|c|c|c|c|c|c|}
\hline & \multicolumn{6}{|c|}{ Dependent Variable $=I N \_L I N E$} \\
\hline & $\begin{array}{c}\text { All Rec's } \\
\text { I. } \\
\end{array}$ & $\begin{array}{c}\text { Upgrades } \\
\text { II. } \\
\end{array}$ & $\begin{array}{c}\text { Downgrades } \\
\text { III. } \\
\end{array}$ & $\begin{array}{c}\text { All Rec's } \\
\text { IV. }\end{array}$ & $\begin{array}{c}\text { Upgrades } \\
\text { V. } \\
\end{array}$ & $\begin{array}{c}\text { Downgrades } \\
\text { VI. }\end{array}$ \\
\hline$I N D \_P A S T \_R E T$ & $\begin{array}{l}-0.551 \\
(-1.21)\end{array}$ & $\begin{array}{l}1.008 \\
(1.53)\end{array}$ & $\begin{array}{c}-2.118 * * * \\
(-3.24)\end{array}$ & $\begin{array}{l}-0.127 \\
(-0.21)\end{array}$ & $\begin{array}{c}2.315^{* *} \\
(2.54)\end{array}$ & $\begin{array}{c}-2.500 * * * \\
(-2.89)\end{array}$ \\
\hline$I N D \_E Q U I T Y$ & $\begin{array}{l}0.003 \\
(1.45)\end{array}$ & $\begin{array}{c}-0.016 * * * \\
(-4.49)\end{array}$ & $\begin{array}{c}0.021^{* * * *} \\
(6.01)\end{array}$ & $\begin{array}{l}-0.003 \\
(-0.85)\end{array}$ & $\begin{array}{c}-0.022 * * * \\
(-4.46)\end{array}$ & $\begin{array}{c}0.014 * * * \\
(3.06)\end{array}$ \\
\hline$T R A D E \_F R E Q$ & $\begin{array}{c}0.033 * * * \\
(3.26)\end{array}$ & $\begin{array}{l}0.002 \\
(0.14)\end{array}$ & $\begin{array}{c}0.064 * * * \\
(4.26)\end{array}$ & $\begin{array}{c}0.030^{* *} \\
(2.09)\end{array}$ & $\begin{array}{l}-0.003 \\
(-0.14)\end{array}$ & $\begin{array}{c}0.061 * * * \\
(2.91)\end{array}$ \\
\hline GENDER & & & & $\begin{array}{l}0.017 \\
(0.29)\end{array}$ & $\begin{array}{l}-0.016 \\
(-0.16)\end{array}$ & $\begin{array}{l}0.063 \\
(0.81)\end{array}$ \\
\hline$A G E$ & & & & $\begin{array}{l}0.001 \\
(0.75)\end{array}$ & $\begin{array}{l}0.003 \\
(1.63)\end{array}$ & $\begin{array}{l}-0.001 \\
(-0.76)\end{array}$ \\
\hline$A B S \_C H G$ & $\begin{array}{c}-0.151^{* * *} \\
(-7.38)\end{array}$ & $\begin{array}{c}-0.204 * * * \\
(-5.32)\end{array}$ & $\begin{array}{l}-0.040 \\
(-1.57)\end{array}$ & $\begin{array}{c}-0.157 * * * * \\
(-5.79)\end{array}$ & $\begin{array}{c}-0.176^{* * * *} \\
(-3.39)\end{array}$ & $\begin{array}{c}-0.074 * * \\
(-2.14)\end{array}$ \\
\hline LOGMARKET & $\begin{array}{l}-0.016 \\
(-1.47)\end{array}$ & $\begin{array}{c}0.082 * * * \\
(4.97)\end{array}$ & $\begin{array}{c}-0.063 * * * \\
(-3.97)\end{array}$ & $\begin{array}{l}0.009 \\
(0.58)\end{array}$ & $\begin{array}{c}0.110^{* * * *} \\
(4.97)\end{array}$ & $\begin{array}{l}-0.040^{*} \\
(-1.87)\end{array}$ \\
\hline$P / E$ & $\begin{array}{c}0.001 * * * \\
(3.66)\end{array}$ & $\begin{array}{c}0.002 * * * \\
(4.61)\end{array}$ & $\begin{array}{l}-0.000 \\
(-0.92)\end{array}$ & $\begin{array}{c}0.001 * * \\
(2.18)\end{array}$ & $\begin{array}{c}0.002 * * * \\
(3.12)\end{array}$ & $\begin{array}{l}-0.001^{*} \\
(-1.86)\end{array}$ \\
\hline$R E T_{-} V O L$ & $\begin{array}{c}-6.771 * * * \\
(-3.48)\end{array}$ & $\begin{array}{c}10.530 * * * \\
(3.73)\end{array}$ & $\begin{array}{c}-18.020 * * * \\
(-6.33)\end{array}$ & $\begin{array}{l}-5.073^{*} \\
(-1.95)\end{array}$ & $\begin{array}{c}15.048 * * * \\
(4.00)\end{array}$ & $\begin{array}{c}-17.840 * * * \\
(-4.66)\end{array}$ \\
\hline$R A W_{-} R E T$ & $\begin{array}{l}0.015 \\
(0.89)\end{array}$ & $\begin{array}{c}-0.214 * * * \\
(-5.93)\end{array}$ & $\begin{array}{c}0.166^{* * * *} \\
(6.72)\end{array}$ & $\begin{array}{l}0.018 \\
(0.80)\end{array}$ & $\begin{array}{c}-0.177 * * * * \\
(-3.65)\end{array}$ & $\begin{array}{c}0.156^{* * * *} \\
(4.83)\end{array}$ \\
\hline BETA & $\begin{array}{l}-0.013 \\
(-0.63)\end{array}$ & $\begin{array}{c}0.122 * * * \\
(3.98)\end{array}$ & $\begin{array}{c}-0.055^{*} \\
(-1.87)\end{array}$ & $\begin{array}{l}-0.018 \\
(-0.68)\end{array}$ & $\begin{array}{c}0.127 * * * \\
(3.03)\end{array}$ & $\begin{array}{l}-0.063 \\
(-1.54)\end{array}$ \\
\hline$R O E$ & $\begin{array}{l}-0.011 \\
(-0.89)\end{array}$ & $\begin{array}{l}0.016 \\
(0.98)\end{array}$ & $\begin{array}{c}-0.067 * * * \\
(-2.93)\end{array}$ & $\begin{array}{l}-0.013 \\
(-0.83)\end{array}$ & $\begin{array}{l}0.006 \\
(0.28)\end{array}$ & $\begin{array}{l}-0.043^{*} \\
(-1.64)\end{array}$ \\
\hline ANALYST_PERF & $\begin{array}{l}-0.420 \\
(-0.51)\end{array}$ & $\begin{array}{l}0.157 \\
(0.13)\end{array}$ & $\begin{array}{l}-0.865 \\
(-0.75)\end{array}$ & $\begin{array}{l}0.531 \\
(0.48)\end{array}$ & $\begin{array}{l}1.886 \\
(1.15)\end{array}$ & $\begin{array}{l}-0.541 \\
(-0.36)\end{array}$ \\
\hline BROKER_SIZE & $\begin{array}{c}-0.001 * * * \\
(-5.41)\end{array}$ & $\begin{array}{l}-0.000 \\
(-1.00)\end{array}$ & $\begin{array}{c}-0.001 * * * \\
(-4.70)\end{array}$ & $\begin{array}{c}-0.001 * * * \\
(-3.82)\end{array}$ & $\begin{array}{l}-0.000 \\
(-0.55)\end{array}$ & $\begin{array}{c}-0.001 * * * \\
(-3.26)\end{array}$ \\
\hline No. of Observations & 33,909 & 15,467 & 18,442 & 18,436 & 8,414 & 10,022 \\
\hline Psuedo $R^{2}$ & 0.01 & 0.02 & 0.03 & 0.01 & 0.03 & 0.03 \\
\hline
\end{tabular}

This table presents an analysis of the determinants of whether individuals trade in line with analyst recommendations using logistic regressions. These regressions only include analyst guidance that are either upgrades or downgrades and trades that are made in event days -1 to +1 . *, **, *** indicate significance at the $0.10,0.05$, and 0.01 levels, respectively, using two-tailed tests. $T$-statistics and $p$-values are calculated using clustered standard errors by individual investor account number. All regressions include year and industry fixedeffects; however, for brevity, these separate intercepts are not reported. See Appendix B for variable definitions. 
TABLE 26

Trading Consistency Regression Analyses: Analysts' Earnings Forecast Revisions

\begin{tabular}{|c|c|c|c|c|c|c|}
\hline & \multicolumn{6}{|c|}{ Dependent Variable $=I N \_L I N E$} \\
\hline & $\begin{array}{c}\text { All } \\
\text { Earnings } \\
\text { Forecasts } \\
\text { I. } \\
\end{array}$ & $\begin{array}{c}\text { Upgrades } \\
\text { II. }\end{array}$ & $\begin{array}{c}\text { Downgrades } \\
\text { III. } \\
\end{array}$ & $\begin{array}{c}\text { All } \\
\text { Earnings } \\
\text { Forecasts } \\
\text { IV. } \\
\end{array}$ & $\begin{array}{c}\text { Upgrades } \\
\text { V. }\end{array}$ & $\begin{array}{c}\text { Downgrades } \\
\text { VI. } \\
\end{array}$ \\
\hline$I N D \_P A S T \_R E T$ & $\begin{array}{c}-0.620 * * * \\
(-3.14)\end{array}$ & $\begin{array}{l}0.262 \\
(0.78)\end{array}$ & $\begin{array}{c}-1.152 * * * \\
(-4.36)\end{array}$ & $\begin{array}{c}-0.730 * * * \\
(-2.69)\end{array}$ & $\begin{array}{l}0.504 \\
(1.02)\end{array}$ & $\begin{array}{c}-1.490 * * * \\
(-4.07)\end{array}$ \\
\hline IND_EQUITY & $\begin{array}{l}0.001 \\
(1.01)\end{array}$ & $\begin{array}{c}-0.015^{* * *} \\
(-8.39)\end{array}$ & $\begin{array}{c}0.011 * * * \\
(7.40)\end{array}$ & $\begin{array}{l}0.002 \\
(1.49)\end{array}$ & $\begin{array}{c}-0.013 * * * \\
(-5.52)\end{array}$ & $\begin{array}{c}0.012 * * * \\
(5.76)\end{array}$ \\
\hline$T R A D E \_F R E Q$ & $\begin{array}{c}0.015^{* * *} \\
(3.47)\end{array}$ & $\begin{array}{c}-0.018 * * \\
(-2.22)\end{array}$ & $\begin{array}{c}0.035 * * * \\
(5.01)\end{array}$ & $\begin{array}{c}0.014 * * \\
(2.36)\end{array}$ & $\begin{array}{l}-0.020^{*} \\
(-1.88)\end{array}$ & $\begin{array}{c}0.033 * * * \\
(3.49)\end{array}$ \\
\hline GENDER & & & & $\begin{array}{c}0.044^{*} \\
(1.81)\end{array}$ & $\begin{array}{l}-0.006 \\
(-0.16)\end{array}$ & $\begin{array}{c}0.068^{* *} \\
(1.97)\end{array}$ \\
\hline$A G E$ & & & & $\begin{array}{c}-0.001 * * * \\
(-2.69)\end{array}$ & $\begin{array}{c}0.003 * * * \\
(3.01)\end{array}$ & $\begin{array}{c}-0.004 * * * \\
(-5.27)\end{array}$ \\
\hline$A B S \_R E C \_C H G$ & $\begin{array}{c}-0.041 * * * \\
(-4.18)\end{array}$ & $\begin{array}{l}-0.004 \\
(-1.38)\end{array}$ & $\begin{array}{c}-0.027 * * \\
(-2.17)\end{array}$ & $\begin{array}{c}-0.055^{* * *} \\
(-8.05)\end{array}$ & $\begin{array}{l}-0.007 \\
(-1.47)\end{array}$ & $\begin{array}{c}-0.047 * * * \\
(-6.62)\end{array}$ \\
\hline LOGMARKET & $\begin{array}{c}-0.014 * * * \\
(-2.66)\end{array}$ & $\begin{array}{c}0.076^{* * * *} \\
(9.03)\end{array}$ & $\begin{array}{c}-0.075^{* * * *} \\
(-9.86)\end{array}$ & $\begin{array}{c}-0.014 * * \\
(-2.08)\end{array}$ & $\begin{array}{c}0.076^{* * *} \\
(6.94)\end{array}$ & $\begin{array}{c}-0.078 * * * \\
(-8.68)\end{array}$ \\
\hline$P / E$ & $\begin{array}{c}-0.000 * * * \\
(-3.06)\end{array}$ & $\begin{array}{l}0.000 \\
(0.48)\end{array}$ & $\begin{array}{c}-0.000 * * * \\
(-2.71)\end{array}$ & $\begin{array}{c}-0.000^{* * * *} \\
(-4.11)\end{array}$ & $\begin{array}{l}-0.000 \\
(-0.84)\end{array}$ & $\begin{array}{c}-0.000 * * * \\
(-3.22)\end{array}$ \\
\hline$R E T \_V O L$ & $\begin{array}{c}-7.507 * * * \\
(-8.93)\end{array}$ & $\begin{array}{c}18.936 * * * \\
(12.59)\end{array}$ & $\begin{array}{c}-20.384 * * * \\
(-18.07)\end{array}$ & $\begin{array}{c}-9.741 * * * \\
(-8.72)\end{array}$ & $\begin{array}{c}19.544 * * * \\
(9.57)\end{array}$ & $\begin{array}{c}-24.209 * * * \\
(-16.30)\end{array}$ \\
\hline$R A W \_R E T$ & $\begin{array}{c}0.108 * * * \\
(12.27)\end{array}$ & $\begin{array}{c}0.027 * * \\
(2.30)\end{array}$ & $\begin{array}{c}0.136 * * * \\
(9.58)\end{array}$ & $\begin{array}{c}0.108^{* * * *} \\
(9.31)\end{array}$ & $\begin{array}{l}0.028^{*} \\
(1.82)\end{array}$ & $\begin{array}{c}0.131 * * * \\
(7.90)\end{array}$ \\
\hline BETA & $\begin{array}{l}-0.005 \\
(-0.54)\end{array}$ & $\begin{array}{c}0.139 * * * \\
(9.68)\end{array}$ & $\begin{array}{c}-0.077 * * * \\
(-6.24)\end{array}$ & $\begin{array}{l}-0.002 \\
(-0.19)\end{array}$ & $\begin{array}{c}0.135^{* * *} \\
(6.93)\end{array}$ & $\begin{array}{c}-0.067 * * * \\
(-4.05)\end{array}$ \\
\hline$R O E$ & $\begin{array}{l}-0.01 \\
(-1.41)\end{array}$ & $\begin{array}{c}0.204 * * \\
(2.36)\end{array}$ & $\begin{array}{c}-0.026^{*} \\
(-1.89)\end{array}$ & $\begin{array}{l}-0.024 * \\
(-1.73)\end{array}$ & $\begin{array}{c}0.348^{* * *} \\
(4.63)\end{array}$ & $\begin{array}{c}-0.049 * * \\
(-2.39)\end{array}$ \\
\hline ANALYST_PERF & $\begin{array}{l}-0.855 \\
(-1.64)\end{array}$ & $\begin{array}{c}-1.610^{*} \\
(-1.96)\end{array}$ & $\begin{array}{l}-0.311 \\
(-0.44)\end{array}$ & $\begin{array}{l}-1.037 \\
(-1.48)\end{array}$ & $\begin{array}{l}-1.336 \\
(-1.22)\end{array}$ & $\begin{array}{l}-0.481 \\
(-0.51)\end{array}$ \\
\hline BROKER_SIZE & $\begin{array}{c}-0.000 * * * \\
(-3.14)\end{array}$ & $\begin{array}{l}0.000 \\
(1.54)\end{array}$ & $\begin{array}{c}-0.001 * * * \\
(-4.05)\end{array}$ & $\begin{array}{c}-0.000 * * \\
(-2.43)\end{array}$ & $\begin{array}{c}0.001 * * \\
(2.03)\end{array}$ & $\begin{array}{c}-0.001 * * * \\
(-3.60)\end{array}$ \\
\hline No. of Observations & 173,124 & 63,458 & 109,666 & 93,733 & 34,459 & 59,274 \\
\hline Psuedo $R^{2}$ & 0.01 & 0.01 & 0.02 & 0.01 & 0.01 & 0.02 \\
\hline
\end{tabular}

This table presents an analysis of the determinants of whether individuals trade in line with analysts' analysts' earnings forecasts using logistic regressions. These regressions only include analyst guidance that are either upgrades or downgrades and trades that are made in event days -1 to $+1 . *, * *, * * *$ indicate significance at the $0.10,0.05$, and 0.01 levels, respectively, using two-tailed tests. $T$-statistics and $p$-values are calculated using clustered standard errors by individual investor account number. All regressions include year and industry fixedeffects; however, for brevity, these separate intercepts are not reported. See Appendix B for variable definitions. 
TABLE 27

Individuals' Six Month Returns Following Analyst Guidance: Univariate Analysis

\begin{tabular}{|c|c|c|c|c|c|c|c|c|}
\hline \multirow{2}{*}{\multicolumn{9}{|c|}{$\begin{array}{l}\text { Panel A: Recommendations and Earnings Forecasts } \\
F U T \_R E T U R N S\end{array}$}} \\
\hline & & & & & & & & \\
\hline & $\mathbf{N}$ & Mean & S.D. & Min & 0.25 & Median & 0.75 & Max \\
\hline All Guidance & 195,382 & $-0.003 * * *$ & 0.231 & -1.000 & -0.120 & 0.004 & 0.119 & 2.423 \\
\hline$I N \_L I N E=0$ & 102,722 & $-0.013 * * *$ & 0.228 & -1.000 & -0.130 & 0.000 & 0.108 & 2.423 \\
\hline$I N \_L I N E=1$ & 92,660 & $0.008^{* * * *}$ & 0.234 & -1.000 & -0.111 & 0.010 & 0.133 & 1.955 \\
\hline Difference & & $-0.021 * * *$ & & 0.000 & -0.019 & -0.010 & -0.025 & 0.468 \\
\hline \multicolumn{9}{|c|}{ Panel B: Recommendations } \\
\hline \multicolumn{9}{|c|}{$F U T \_R E T U R N S$} \\
\hline & $\mathbf{N}$ & Mean & S.D. & Min & 0.25 & Median & 0.75 & Max \\
\hline All Recommendations & 32,123 & $-0.003 * *$ & 0.235 & -1.000 & -0.122 & 0.006 & 0.124 & 1.791 \\
\hline$I N \_L I N E=0$ & 17,385 & $-0.010 * * *$ & 0.237 & -1.000 & -0.134 & 0.001 & 0.117 & 1.791 \\
\hline$I N \_L I N E=1$ & 14,738 & $0.007 * * *$ & 0.233 & -1.000 & -0.112 & 0.013 & 0.131 & 1.428 \\
\hline Difference & & $-0.017 * * *$ & & 0.000 & -0.022 & -0.012 & -0.014 & 0.363 \\
\hline \multicolumn{9}{|c|}{ Panel C: Earnings Forecasts } \\
\hline \multicolumn{9}{|l|}{$F U T \_R E T U R N S$} \\
\hline & $\mathbf{N}$ & Mean & S.D. & Min & 0.25 & Median & 0.75 & Max \\
\hline All Earnings Forecasts & 163,259 & $-0.003 * * *$ & 0.230 & -1.000 & -0.120 & 0.004 & 0.118 & 2.423 \\
\hline$I N \_L I N E=0$ & 85,337 & $-0.013 * * *$ & 0.226 & -1.000 & -0.130 & 0.000 & 0.107 & 2.423 \\
\hline$I N \_L I N E=1$ & 77,922 & $0.008 * * *$ & 0.234 & -1.000 & -0.111 & 0.009 & 0.133 & 1.955 \\
\hline Difference & & $-0.021 * * *$ & & 0.000 & -0.019 & -0.009 & -0.026 & 0.468 \\
\hline
\end{tabular}

This table presents the descriptive statistics for individuals' returns in the six months following analyst guidance. $* *, * * *$ indicate significance at the 0.05 and 0.01 levels, respectively, using two-tailed tests. See Appendix B for variable definitions. 
TABLE 28

Individuals' Future Returns Following Analyst Guidance: Regression Analysis

\begin{tabular}{|c|c|c|c|}
\hline & \multicolumn{3}{|c|}{ Dependent Variable = FUT_RETURNS } \\
\hline & $\begin{array}{l}\text { Recommendations } \\
\text { and Earnings } \\
\text { Forecasts } \\
\text { I. } \\
\end{array}$ & $\begin{array}{c}\text { Recommendations } \\
\text { II. }\end{array}$ & $\begin{array}{c}\text { Earnings Forecasts } \\
\text { III. }\end{array}$ \\
\hline$I N \_L I N E$ & $\begin{array}{c}0.021 * * * \\
(17.71)\end{array}$ & $\begin{array}{c}0.016 * * * \\
(5.65)\end{array}$ & $\begin{array}{c}0.021 * * * \\
(16.75)\end{array}$ \\
\hline$A B S \_C H G$ & $\begin{array}{l}0.000 \\
(0.86)\end{array}$ & $\begin{array}{l}0.000 \\
(0.13)\end{array}$ & $\begin{array}{l}0.000 \\
(0.90)\end{array}$ \\
\hline UPGRADE & $\begin{array}{c}-0.008 * * * \\
(-6.71)\end{array}$ & $\begin{array}{l}0.002 \\
(0.69)\end{array}$ & $\begin{array}{c}-0.010 * * * \\
(-7.62)\end{array}$ \\
\hline$I N D \_P A S T \_R E T$ & $\begin{array}{l}-0.008 \\
(-0.30)\end{array}$ & $\begin{array}{l}0.013 \\
(0.22)\end{array}$ & $\begin{array}{l}-0.013 \\
(-0.49)\end{array}$ \\
\hline FUT_BETA & $\begin{array}{l}-0.003 * \\
(-1.90)\end{array}$ & $\begin{array}{l}-0.004 \\
(-1.23)\end{array}$ & $\begin{array}{l}-0.002 \\
(-1.59)\end{array}$ \\
\hline$S M B$ & $\begin{array}{l}-0.000 \\
(-0.46)\end{array}$ & $\begin{array}{l}-0.004 * \\
(-1.65)\end{array}$ & $\begin{array}{l}-0.000 \\
(-0.04)\end{array}$ \\
\hline$H M L$ & $\begin{array}{c}0.004 * * * \\
(4.89)\end{array}$ & $\begin{array}{c}0.008 * * * \\
(5.03)\end{array}$ & $\begin{array}{c}0.003 * * * \\
(3.67)\end{array}$ \\
\hline CARHART_MOMENTUM & $\begin{array}{c}-0.002 * * * \\
(-3.45)\end{array}$ & $\begin{array}{c}-0.005 * * * \\
(-3.67)\end{array}$ & $\begin{array}{c}-0.002 * * * \\
(-2.58)\end{array}$ \\
\hline RECOMMENDATION & $\begin{array}{l}0.002 \\
(1.31)\end{array}$ & & \\
\hline No. of Observations & 195,382 & 32,123 & 163,259 \\
\hline Psuedo $R^{2}$ & 0.01 & 0.01 & 0.01 \\
\hline
\end{tabular}

This table presents an analysis of individuals' six month returns following analysts' recommendations and earnings forecast guidance. These regressions only include analyst guidance that are either upgrades or downgrades and trades that are made in event days -1 to $+1 . *, * *, * * *$ indicate significance at the 0.10 , 0.05 , and 0.01 levels, respectively, using two-tailed tests. $T$-statistics and $p$-values are calculated using clustered standard errors by individual investor account number. All regressions include year and industry fixed-effects; however, for brevity, these separate intercepts are not reported. See Appendix B for variable definitions. 
TABLE 29

Individuals' Attributes and Future Returns Following Analyst Guidance Regression Analysis

\begin{tabular}{|c|c|c|c|c|c|}
\hline & \multicolumn{5}{|c|}{ Dependent Variable $=\boldsymbol{F U T} \_\boldsymbol{R E T U} \boldsymbol{R N} \boldsymbol{S}$} \\
\hline & $\begin{array}{c}I N T=I N D \\
\_P A S T \_R E T\end{array}$ & $\begin{array}{l}I N T=I N D \\
\_E Q U I T Y\end{array}$ & $\begin{array}{c}I N T=T R A D E \\
\quad F R E Q\end{array}$ & $\begin{array}{c}I N T= \\
G E N D E R\end{array}$ & $I N T=A G E$ \\
\hline & I. & II. & III. & IV. & V. \\
\hline IN_LINE & $\begin{array}{c}0.021 * * * \\
(17.77)\end{array}$ & $\begin{array}{c}0.033 * * * \\
(17.32)\end{array}$ & $\begin{array}{c}0.011 * * * \\
(3.97)\end{array}$ & $\begin{array}{c}0.021 * * * \\
(13.18)\end{array}$ & $\begin{array}{c}0.046^{* * * *} \\
(7.11)\end{array}$ \\
\hline$I N T * I N \_L I N E$ & $\begin{array}{l}-0.047 \\
(-0.91)\end{array}$ & $\begin{array}{c}-0.002 * * * \\
(-8.30)\end{array}$ & $\begin{array}{c}0.004 * * * \\
(3.90)\end{array}$ & $\begin{array}{l}0.003 \\
(0.51)\end{array}$ & $\begin{array}{c}-0.000 * * * \\
(-3.88)\end{array}$ \\
\hline INT & & $\begin{array}{c}0.001 * * * \\
(4.49)\end{array}$ & $\begin{array}{l}-0.001^{*} \\
(-1.88)\end{array}$ & $\begin{array}{l}0.000 \\
(0.12)\end{array}$ & $\begin{array}{c}0.000 * * * \\
(4.14)\end{array}$ \\
\hline$A B S \_R E C \_C H G$ & $\begin{array}{l}0.000 \\
(0.86)\end{array}$ & $\begin{array}{l}0.000 \\
(0.91)\end{array}$ & $\begin{array}{l}0.000 \\
(0.84)\end{array}$ & $\begin{array}{l}0.000 \\
(0.74)\end{array}$ & $\begin{array}{l}0.000 \\
(0.62)\end{array}$ \\
\hline UPGRADE & $\begin{array}{c}-0.008 * * * \\
(-6.70)\end{array}$ & $\begin{array}{c}-0.008^{* * * *} \\
(-7.07)\end{array}$ & $\begin{array}{c}-0.008 * * * \\
(-6.66)\end{array}$ & $\begin{array}{c}-0.008 * * * \\
(-5.07)\end{array}$ & $\begin{array}{c}-0.008 * * * \\
(-5.09)\end{array}$ \\
\hline IND_PAST_RET & $\begin{array}{l}0.015 \\
(0.44)\end{array}$ & $\begin{array}{l}-0.007 \\
(-0.27)\end{array}$ & $\begin{array}{l}-0.008 \\
(-0.32)\end{array}$ & $\begin{array}{l}-0.004 \\
(-0.12)\end{array}$ & $\begin{array}{l}-0.006 \\
(-0.16)\end{array}$ \\
\hline FUT_BETA & $\begin{array}{l}-0.003^{*} \\
(-1.90)\end{array}$ & $\begin{array}{l}-0.003^{*} \\
(-1.89)\end{array}$ & $\begin{array}{l}-0.003^{*} \\
(-1.94)\end{array}$ & $\begin{array}{l}-0.003 \\
(-1.44)\end{array}$ & $\begin{array}{l}-0.002 \\
(-1.27)\end{array}$ \\
\hline$S M B$ & $\begin{array}{l}-0.000 \\
(-0.46)\end{array}$ & $\begin{array}{l}-0.000 \\
(-0.46)\end{array}$ & $\begin{array}{l}-0.001 \\
(-0.53)\end{array}$ & $\begin{array}{l}0.001 \\
(0.61)\end{array}$ & $\begin{array}{l}0.001 \\
(0.62)\end{array}$ \\
\hline$H M L$ & $\begin{array}{c}0.004 * * * \\
(4.89)\end{array}$ & $\begin{array}{c}0.004 * * * \\
(4.83)\end{array}$ & $\begin{array}{c}0.004 * * * \\
(5.02)\end{array}$ & $\begin{array}{c}0.003 * * * \\
(3.45)\end{array}$ & $\begin{array}{c}0.003 * * * \\
(2.95)\end{array}$ \\
\hline CARHART_MOMENTUM & $\begin{array}{c}-0.002 * * * \\
(-3.45)\end{array}$ & $\begin{array}{c}-0.002 * * * \\
(-3.44)\end{array}$ & $\begin{array}{c}-0.002 * * * \\
(-3.50)\end{array}$ & $\begin{array}{c}-0.002 * * \\
(-2.19)\end{array}$ & $\begin{array}{l}-0.002 * \\
(-1.84)\end{array}$ \\
\hline RECOMMENDATION & $\begin{array}{l}0.002 \\
(1.31)\end{array}$ & $\begin{array}{l}0.002 \\
(1.38)\end{array}$ & $\begin{array}{l}0.002 \\
(1.31)\end{array}$ & $\begin{array}{l}0.000 \\
(0.23)\end{array}$ & $\begin{array}{l}0.001 \\
(0.47)\end{array}$ \\
\hline No. of Observations & 195,382 & 195,382 & 195,382 & 112,239 & 105,682 \\
\hline Psuedo $R^{2}$ & 0.01 & 0.01 & 0.01 & 0.01 & 0.01 \\
\hline
\end{tabular}

This table presents an analysis of how individuals' attributes affect their six month returns following analysts' recommendations and earnings forecast guidance. These regressions only include analyst guidance that are either upgrades or downgrades and trades that are made in event days -1 to +1 . *,**, *** indicate significance at the $0.10,0.05$, and 0.01 levels, respectively, using two-tailed tests. $T$-statistics and $p$-values are calculated using clustered standard errors by individual investor account number. All regressions include year and industry fixedeffects; however, for brevity, these separate intercepts are not reported. See Appendix B for variable definitions. 